Pós-Graduação em

Desenvolvimento Sustentável

\title{
Saberes e Sabores da Cultura Kalunga:
}

Origens e consequências das alterações nos sistemas alimentares

Cecilia Ricardo Fernandes

Dissertação de Mestrado

Brasília - DF, dezembro/2014

Universidade de Brasília - UnB

Centro de Desenvolvimento Sustentável - CDS 
UNIVERSIDADE DE BRASÍLIA

CENTRO DE DESENVOLVIMENTO SUSTENTÁVEL

\section{Saberes e Sabores da Cultura Kalunga:}

Origens e consequências das alterações nos sistemas alimentares

Cecilia Ricardo Fernandes

Orientador: José Luiz de Andrade Franco

Co-orientadora: Ludivine Eloy

Dissertação de Mestrado

Brasília - DF, dezembro de 2014 
Fernandes, Cecilia Ricardo

Saberes e Sabores Kalungas: origens e consequências das alterações nos sistemas alimentares./ Cecilia Ricardo Fernandes. Brasília, 2014.

139 p.: il.

Dissertação de Mestrado. Centro de Desenvolvimento Sustentável. Universidade de Brasília, Brasília.

1. Segurança Alimentar. 2. Agrobiodiversidade. 3.

Território Quilombola. 4.Cerrado. I. Universidade de Brasília. CDS.

II. Título.

É concedida à Universidade de Brasília permissão para reproduzir cópias desta dissertação e emprestar ou vender tais cópias, somente para propósitos acadêmicos e científicos. A autora reserva outros direitos de publicação e nenhuma parte desta dissertação de mestrado pode ser reproduzida sem a autorização por escrito da autora. 
UNIVERSIDADE DE BRASÍLIA

CENTRO DE DESENVOLVIMENTO SUSTENTÁVEL

\section{Saberes e Sabores Kalungas:}

Origens e consequências das alterações nos sistemas alimentares

Cecilia Ricardo Fernandes

Dissertação de Mestrado submetida ao Centro de Desenvolvimento Sustentável da Universidade de Brasília, como parte dos requisitos necessários para a obtenção do Grau de Mestre em Desenvolvimento Sustentável.

Aprovado por:

José Luiz de Andrade Franco, Doutor (CDS/UnB)

(Orientador)

Doris Saraygo, Doutora (CDS/UnB)

(Examinador Interno)

Mônica Celeida Rabelo, Doutora (FUP/UnB)

(Examinador Externo)

Brasília-DF, 15 de dezembro de 2014. 
À minha mãe, por ter me ensinado o amor pela cultura.

E ao meu pai, por ter me ensinado o amor pela natureza. 


\section{AGRADECIMENTOS}

Agradeço, primeiramente, a todas as famílias Kalungas que me receberam tão calorosa e atenciosamente em seus lares e em suas terras, tornando minha pesquisa de campo sempre agradável, instrutiva, saborosa e divertida.

Agradeço aos professores e colegas que tanto me ensinaram ao longo destes dois anos, apresentando-me as mais diversas áreas do conhecimento, graças a uma vivência que só ocorrre em ambientes interdisciplinares, como o que encontrei no CDS.

Agradeço ao professor José Luiz de Andrade Franco por ter acreditado desde o início nas minhas capacidades académicas, mesmo quando eu não acreditava, me instruindo, direcionando e podando sempre que necessário.

Agradeço à professora Ludivine Eloy que me acolheu e guiou nessa jornada, por apresentar-me a um universo teórico, até então desconhecido, e ao mundo das pesquisas de campo.

Agradeço ao Betão, à Claudinha, ao Domingos, à Divina, ao Calixto e à Fiota por terem colaborado tão prontamente com a pesquisa de campo, com as apresentações, caronas, estadias e refeições.

Agradeço aos amigos de Cavalcante por terem feito com que eu me sentisse em casa desde meu primeiro dia na cidade e por me alegrarem e consolarem sempre que precisei.

Agradeço a todos os funcionários da Pousada Aruana que cuidaram de mim com enorme carinho e atenção, tornando-a meu segundo lar (com wi-fi).

Agradeço a Mari, amiga-irmã, por ter me ajudado a manter a sanidade nos momentos difíceis e por compartilhar a euforia nos momentos alegres.

Agradeço aos meus irmãos, Nina, Matheus, Raphael e Daniela, por todo o carinho e pela oportunidade de ser um exemplo melhor.

Mas acima de tudo, eu agradeço aos meus pais e aos meus avôs por todo o investimento que fizeram na minha educação ao longo dos anos, garantindo que nada me faltasse e permitindo que eu me sentisse livre para escolher meu próprio caminho. 
"O alimento não é uma mercadoria, é um direito humano."

Camila Montecinos 


\section{RESUMO}

Esta pesquisa analisa o impacto de políticas sociais e alimentares na segurança alimentar de populações tradicionais do Cerrado, escolhendo como estudo de caso o território quilombola Kalunga, localizado no nordeste goiano. A partir de observação participante, de entrevistas, de percursos comentados e de mapeamento participativo em duas comunidades (Engenho II e Vão de Almas), identificamos as principais características e transformações dos sistemas produtivos e alimentares. Além disso, aplicamos 11 questionários para avaliar o estado da segurança alimentar das famílias. O turismo, as distribuições de cestas básicas e os programas de transferência condicionada de renda influenciam diretamente as estratégias produtivas e práticas alimentares, porém sem levar ao abandono das práticas agrícolas tradicionais e da agrobiodiversidade. Ao adotar estratégias de diversificação de renda, baseadas na multilocalidade e na mobilidade entre comunidade e cidades, a maior parte das famílias consegue diminuir sua insegurança alimentar. Isso nem sempre implica na soberania alimentar, e por isso refletimos sobre um aprimoramento destas politicas públicas.

Palavras-chave: Segurança Alimentar; Agrobiodiversidade; Território Quilombola; Cerrado. 


\begin{abstract}
In this research we have sought to analyze the impact of social and food policies in nutritional safety of traditional populations of the Cerrado, choosing as a case study the Kalunga quilombola community, located at the Northeast of the state of Goiás. By means of participative observation, interviews, commented routes, and participative mapping in two communities (Engenho II and Vão de Almas), we have identified the main characteristics and transformations of the productive and nutritional systems. In addition, we have applied 11 questionnaires to assess the nutritional safety status of the families. Tourism, distribution of cestas básicas [a prepacked collection of the basic monthly consumables for a family of four], and the conditional income transfer programs directly influence the production strategies and nutritional habits, although not leading to the abandonment of traditional farming. When adopting income diversification strategies, based on multi-sited households and mobility between communities and cities, most families are able to reduce their nutritional insecurity. That seldom implies food sovereignty, and thus we reflect on an improvement of these public policies.
\end{abstract}

Keywords: Nutritional safety; Agrobiodiversity; Quilombola territory; Cerrado. 


\section{RÉSUMÉ}

Nous avons analysé l'impact des politiques sociales et alimentaires sur la sécurité alimentaire des populations traditionnelles du Cerrado, en se basant sur l'étude de cas du territoire quilombola Kalunga, situé dans le nord de l'Etat de Goiás. Grâce à l'observation participante, des entretiens, des parcours commentés avec les agriculteurs et la cartographie participative, nous avons identifié les principales caractéristiques et les transformations des systèmes de production et des pratiques alimentaires dans deux villages (Engeno II et Vão de Almas). De plus, nous avons appliqué 11 questionnaires pour évaluer l'état de la sécurité alimentaire des ménages. Le tourisme, la distribution de paniers alimentaires et les programmes de transferts monétaires influencent les stratégies de production et les pratiques alimentaires, mais sans pour autant impliquer l'abandon des pratiques agricoles traditionnelles et de l'agrobiodiversité. En adoptant des stratégies de diversification de revenus, basés sur multilocalité résidentielle et la mobilité entre les villages et la villes, la plupart des familles réduisent leur insécurité alimentaire. Cela n'implique pas toujours leur souveraineté alimentaire, c'est pourquoi nous menons une réflexion sur l'amélioration de ces politiques publiques.

Mots-clés: sécurité alimentaire; agrobiodiversité; territoire quilombola; Cerrado 


\section{LISTA DE FIGURAS}

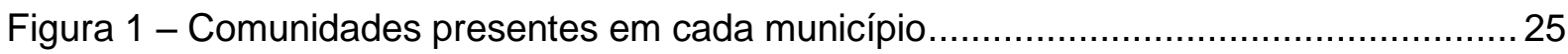

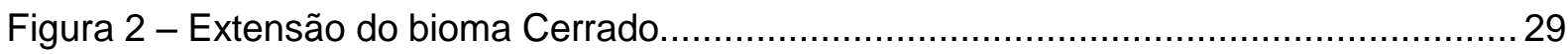

Figura 3 - Uso do solo e cobertura vegetal no estado do Goiás ........................................ 32

Figura 4 - Unidades de Conservação dentro da RESBIO Cerrado ....................................... 33

Figura 5 - Proporção de vegetação natural nas áreas prioritárias do estado do Goiás........ 34

Figura 6 - Porcentagem de famílias participantes do Bolsa Família .................................... 37

Figura 7 - Declaração de cor, em porcentagem, nos municípios ........................................ 38

Figura 8 - Comparação entre dados relacionados à cor da população................................. 38

Figura 9 - Porcentagem dos grupos de populações tradicionais ....................................... 39

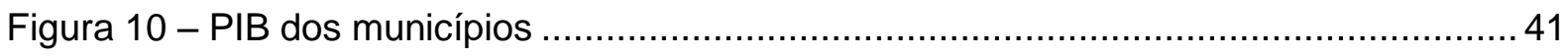

Figura 11 - Bendito de Mesa durante a Festa de Santo Antônio …………........................... 45

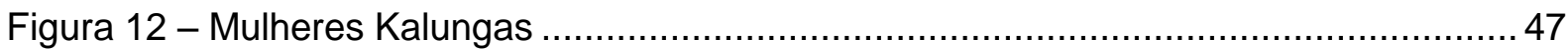

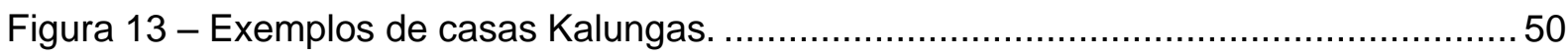

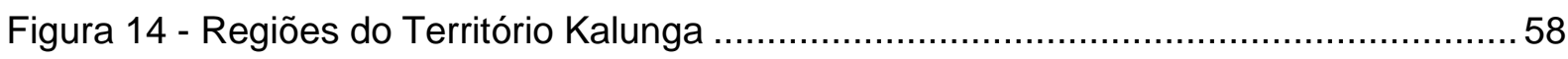

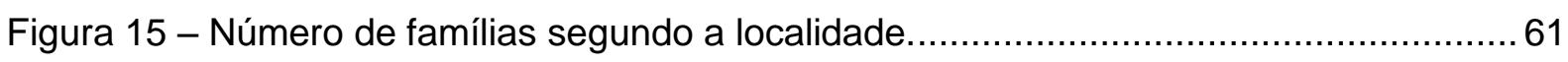

Figura 16 - Roça de toco com plantio de feijão, na Bucaina.............................................. 63

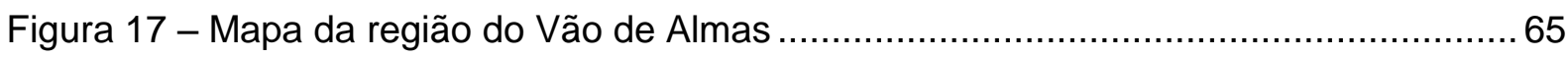

Figura 18 - Estrada que dá acesso as comunidades do Vão de Almas ................................. 68

Figura 19 - Mulheres e crianças tomando banho e lavando utensílios .................................... 69

Figura 20 - Uso e ocupação do território na comunidade do Engenho II ...............................73

Figura 21 - Algumas das variedades de cultivos encontradas na comunidade Kalunga......79

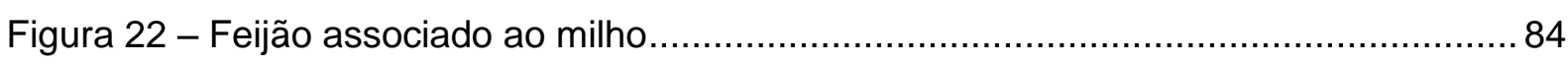

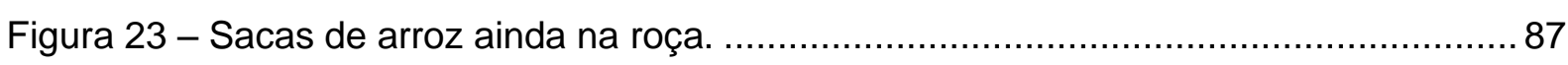

Figura 24 - Projeção da área do Engenho II e do Vão de Almas, ...................................... 91

Figura 25 - Casa Kalunga do Vão de Almas e Roça do Engenho. ...................................... 96

Figura 26 - Pequi em diversos estados de processamento. .......................................... 100

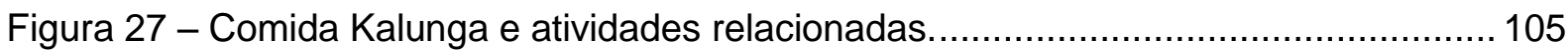

Figura 28 - Porcentagem da renda em relação às atividades econômicas.......................... 114

Figura 29 - Porcentagem das famílias em relação ao estado de segurança alimentar ...... 125

Figura 30 - Desenho esquemático. ........................................................................ 125 


\section{LISTA DE TABELAS}

Tabela 1 - Distribuição percentual dos domicílios .24

Tabela 2 - Número de famílias e de habitantes quilombolas Kalungas ................................ 36

Tabela 3 - Número de famílias e pessoas por localidade Kalunga ..................................... 43

Tabela 4 - Calendário das Folias, Festas e atividades agrícolas ......................................... 46

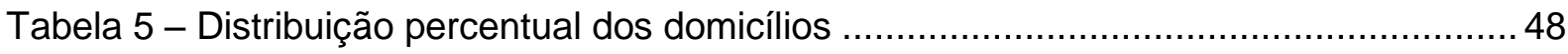

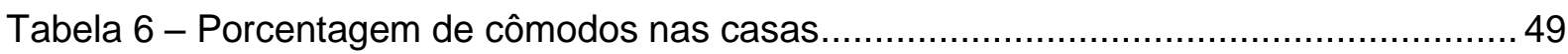

Tabela 7 - Distribuição dos domicílios, segundo o povoado. ........................................... 60

Tabela 8 - Distribuição percentual dos domicílios, segundo a cultura de subsistência ........ 77

Tabela 9 - Espécies e variedades mais encontradas nas 29 roças visitadas .....................77

Tabela 10 - Ciclo produtivo anual de algumas variedades cultivadas.............................. 81

Tabela 11 - Roças da comunidade Engenho II..........................................................92

Tabela 12 - Áreas (fazendas) da parcela oeste da região do Vão de Almas ...................... 93

Tabela 13 - Plantas identificadas nos quintais Kalungas............................................... 95

Tabela 14 - Listagem das espécies alimentícias extraídas do cerrado ..............................98

Tabela 15 - Alimentos consumidos pela manhã na comunidade Kalunga......................... 104

Tabela 16 - Principais ingredientes do almoço e do jantar nas comunidades Kalungas. ... 106

Tabela 17 - Temperos típicos da culinária Kalunga................................................... 106

Tabela 18 - Pratos típicos da culinária Kalunga. ..................................................... 107

Tabela 19 - Principais produtos alimentares comprados .............................................. 108

Tabela 20 - Composição da cesta básica distribuída pela CONAB ................................. 109

Tabela 21 - Distribuição percentual dos domicílios ...................................................... 113

Tabela 22 - Quadro síntese das alterações de cada uma das comunidades.................... 120

Tabela 23 - Perguntas Utilizadas para avaliar a insegurança alimentar ........................... 122 


\section{LISTA DE ABREVIATURAS E SIGLAS}

AKC - Associação Kalunga de Cavalcante

AKMA - Associação Kalunga de Monte Alegre

AKT - Associação Kalunga de Teresina

AQK - Associação Quilombo Kalunga

CAT - Centro de Atendimento ao Turista

CONAB - Companhia Nacional de Abastecimento

EBIA - Escala Brasileira de Medida de Insegurança Alimentar

EMBRAPA - Empresa Brasileira de Pesquisa Agropecuária

EPOTECAMPO - Associação de Educação do Campo do Território Kalunga e Comunidades Rurais

FAO - Organização das Nações Unidas para Alimentação e Agricultura

FBB - Fundação Banco do Brasil

Fubra - Fundação Universidade de Brasília

IBGE - Instituto Brasileiro de Geografia e Estatística

IDAGO - Instituto de Desenvolvimento Agrário de Goiás

MaB - Man and the Biosphere

MDS - Ministério do Desenvolvimento Social e Combate a Fome

MEC - Ministério da Educação e Cultura

MMA - Ministério do Meio Ambiente

ONG - Organização não Governamental

PBF - Programa Bolsa Família

PENAP - Plano Estratégico Nacional de Áreas Protegidas

PIB - Produto Interno Bruto

PNCV - Parque Nacional da Chapada dos Veadeiros

RCB - Reserva da Biosfera Cerrado

SEBRAE - Serviço Brasileiro de Apoio às Micro e Pequenas Empresas

SEPPIR - Secretaria de Politicas de Promoção da Igualdade Racial

SHCK - Sítio Histórico e Cultural Kalunga

TCR - Transferência Condicionada de Renda

UFG - Universidade de Goiás

UnB - Universidade de Brasília 


\section{SUMÁRIO}

Lista de Figuras
Lista de Tabelas
Lista de Abreviaturas e Siglas

Capítulo 1 - Os Kalungas: História, ambiente e cultura ......................................... 18

$1.1 \quad$ Escravidão e Quilombagem ........................................................ 18

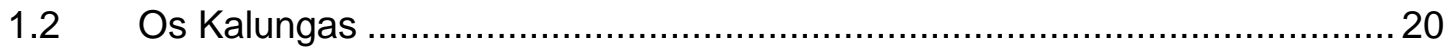

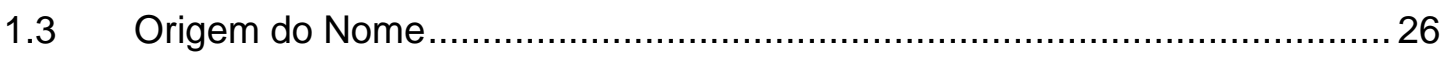

1.4 Quilombolas e Indígenas.............................................................. 27

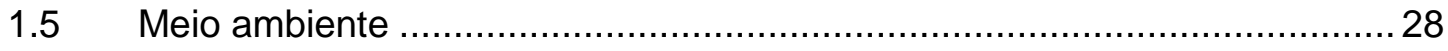

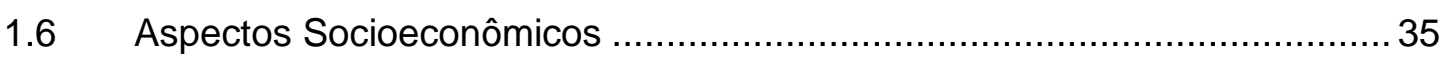

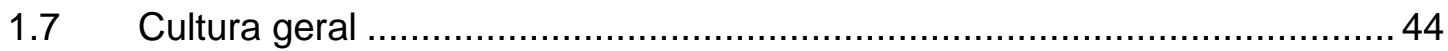

1.7.1 Festas, Danças e Música ......................................................... 44

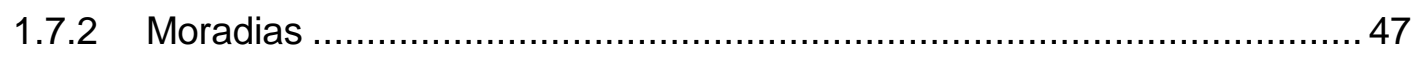

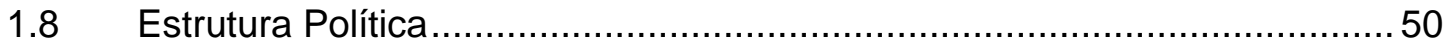

Capitulo 2 - Escolhas Para Percorrer a Trilha .................................................... 52

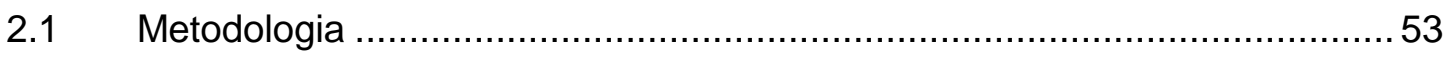

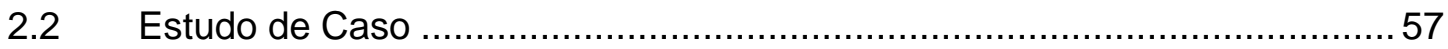

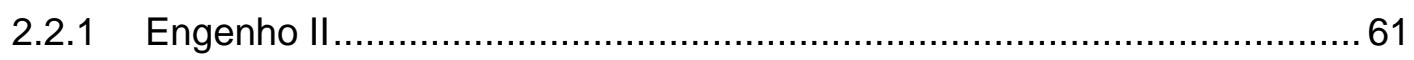

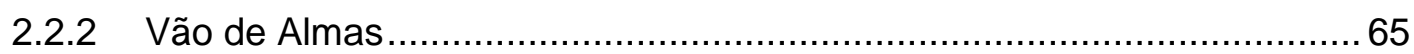

Capítulo 3 - Sistema Alimentar da Comunidade Kalunga........................................... 70

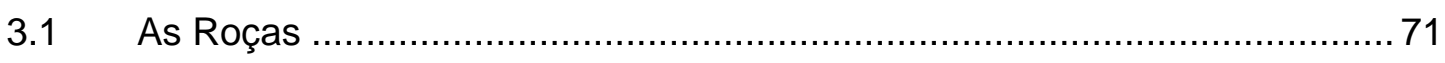

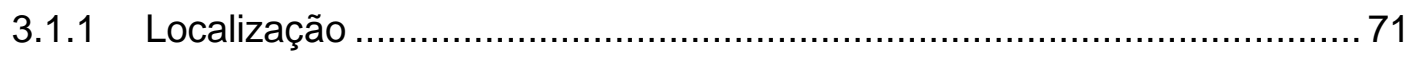

3.1.2 Técnicas, Manejo e Equipamentos................................................. 74

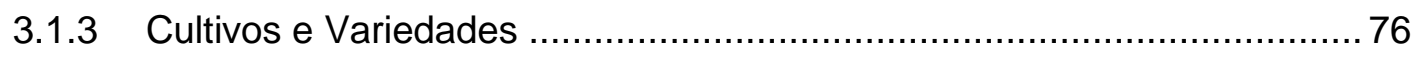

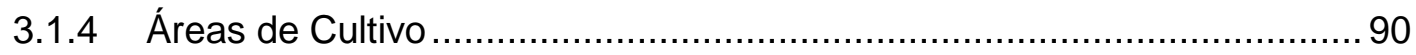




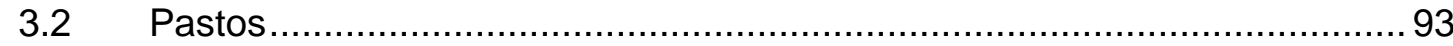

3.3 O quintal, a Horta e o Pomar .............................................................. 94

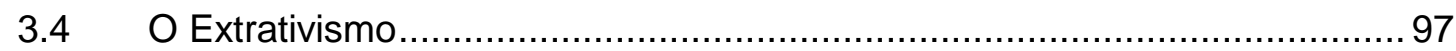

3.5 A Cozinha e o Paladar Identitário ............................................................ 100

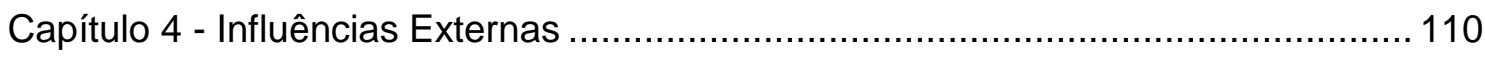

4.1 Os programas de transferência de renda ................................................ 110

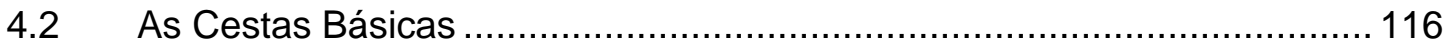

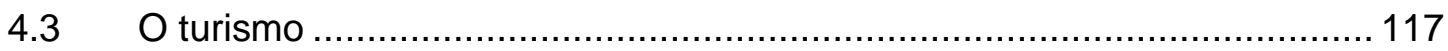

4.4 Alterações e Permanências do Sistema Alimentar Kalunga ......................119

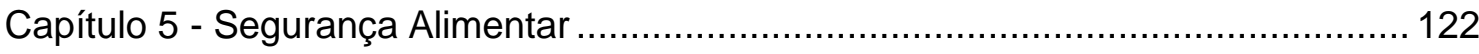

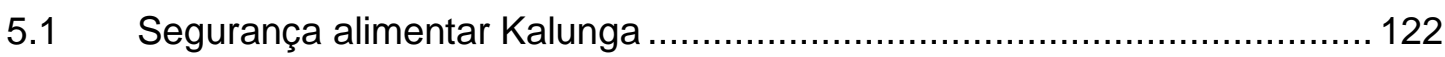

5.2 Segurança alimentar versus soberania alimentar ................................. 126

5.3 Repensando politicas publicas alimentares.......................................... 127

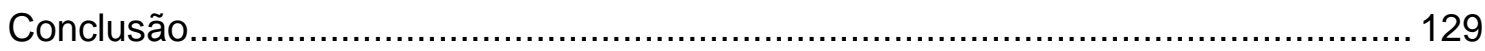

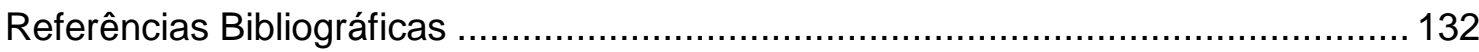




\section{INTRODUÇÃO}

Comer para preservar. Apesar de parecer uma sentença contraditória, essa é uma estratégia que vem sendo adotada por diversas associações (como o Slow Food), ONGs e pesquisadores ao redor do mundo para preservar a agrobiodiversidade e seus saberes associados. É através da alimentação, aspecto comum a todos os seres, que os humanos não só satisfazem as suas necessidades básicas, mas também expressam a sua cultura. Ela se revela no cultivo de espécies alimentícias, nas formas de cozimento, preparação, corte e tempero. "Muito mais do que um ato biológico, a alimentação humana é um ato social e cultural" (MACIEL, 2004, p.25), ela envolve escolhas, símbolos, gestos e combinação de ingredientes. Cozinhar é o espaço compartilhado entre memória e identidade (PETRINI, 2009), e como tal define não só o que se come, mas aquele que

come. É um identificador de grupos e pode se transformar em marcador identitário, símbolo de uma identidade reivindicada (MACIEL, 2005).

Seja por meio da agricultura ou do extrativismo, espécies alimentícias e medicinais foram selecionadas durante milhares de anos. Entretanto, nas últimas décadas, principalmente nos últimos cinquenta anos, iniciou-se um movimento de diminuição da agrobiodiversidade que levou à padronização das espécies alimentícias (SARDO, 2008).

A agrobiodiversidade, ou biodiversidade agrícola, é aquela da qual o ser humano depende para "obter alimentos, combustíveis e fibras, incluindo plantas, animais e outros organismos" (CANCI, 2006) e que se caracteriza pelo intenso manejo (CROMWELL, COOPER e MULVANY, 2003). É, segundo Emperaire (2006), o conjunto dos elementos bióticos em interação em um agroecossistema, os recursos domesticados ou cultivados resultantes de um processo cumulativo de conhecimentos, de uma transmissão temporal através de gerações, mas também espacial e com a circulação do material fitogenético praticada em um determinado espaço geográfico. Estima-se que na atualidade sejam cultivadas menos de $2,5 \%$ das espécies antes conhecidas no mundo. Junto com esse desaparecimento de agrobiodiversidade e germoplasma, ocorre a perda de um patrimônio valioso de saberes, que comumente estão relacionados aos sistemas produtivos e alimentares das comunidades detentoras desse patrimônio.

Por isso, no ano de 2013, a Organização das Nações Unidas para Alimentação e Agricultura (FAO), em comemoração ao dia mundial da alimentação, lançou o slogan "Pessoas saudáveis dependem de sistemas alimentares saudáveis", com a finalidade de chamar a atenção para a importância de todos os níveis dos sistemas alimentares para a 
segurança das comunidades. Segundo a FAO, sistemas alimentares são "o meio ambiente, as pessoas, as instituições e os processos pelos quais os produtos agrícolas são produzidos, processados e levados aos consumidores" (FAO, 2013). Esse conceito está intimamente relacionado com a ideia de segurança alimentar, que segundo a Lei Orgânica de Segurança Alimentar e Nutricional (Losan) (Lei $n^{\circ} 11.346$, de 15 de julho de 2006), é definida como:

[...] a realização do direito de todos ao acesso regular e permanente a alimentos de qualidade, em quantidade suficiente, sem comprometer o acesso a outras necessidades essenciais, tendo como base práticas alimentares promotoras de saúde, que respeitem a diversidade cultural e que sejam social, econômica e ambientalmente sustentáveis(BRASIL, 1996).

O conceito de segurança alimentar surgiu após o final da Segunda Guerra Mundial e é uma das bases para políticas públicas compensatórias, também chamadas de programas de Transferência Condicionada de Renda (TCR). Além de se basearem em três pilares principais (quantidade, qualidade e regularidade), as políticas públicas de segurança alimentar também devem estar em sintonia com "elementos e/ou valores fundamentais da população", como saúde, higiene, meio ambiente, autenticidade e solidariedade. (TRALDI, ALMEIDA e FERRANT, 2012).

O presente trabalho enfoca o aspecto, acima citado, da autenticidade, dando atenção para os valores tradicionais dos sistemas alimentares de comunidades quilombolas do cerrado, com o estudo de caso do território quilombola Kalungas, no nordeste de Goiás. Este território forma a maior comunidade quilombola do Brasil, localizada nos municípios de Cavalcante, Teresina e Monte Alegre, no nordeste de Goiás, e abarca grande área de cerrado conservado da microrregião Chapada dos Veadeiros. Os remanescentes de quilombolas da comunidade Kalunga têm passado, nos últimos trinta anos, por um acelerado processo de mudanças culturais, em que a chegada de escolas, eletricidade, estradas, turismo, bolsas assistenciais e mercadorias industrializadas têm afetado as práticas produtivas, os hábitos alimentares e a agrobiodiversidade local. Nesta pesquisa, procuramos analisar o impacto de políticas sociais e alimentares na segurança alimentar destas comunidades.

Sobre esses temas existem muitas ideias estabelecidas, tanto populares como acadêmicas, que estabelecem relações diretas entre o auxilio monetário governamental e o abandono das práticas produtivas tradicionais, apontando para uma desestruturação desses sistemas agroextrativistas. Nas cidades que circundam o território quilombola Kalunga esses "pré-conceitos" também estão presentes, e são comumente verbalizados quando o assunto é os sistemas produtivos dessa comunidade, como se observa no trecho abaixo: 
Acho muito complicado esse sistema de dar dinheiro para as pessoas. Isso estimula com que elas parem de plantar. [...]. Aí acaba que o povo fica preguiçoso, não quer mais fazer nenhum tipo de serviço, nem roça, nem nada, porque já tem a renda do mês garantida (Professora aposentada residente em Cavalcante, entrevistada em maio de 2014).

Por outro lado, estudos demonstram que as adaptações de comunidades tradicionais resultantes da urbanização e da implementação de políticas públicas (fundiárias, alimentares e produtivas) são processos mais complexos, que por vezes envolvem dinâmicas de diversificação de renda e multilocalidade residencial, como é o caso de comunidades indígenas da Amazônia (ELOY, 2009). Outras pesquisas tem relacionado os programas de transferência condicionada de renda com o aumento da segurança alimentar das comunidades atendidas (ANSCHAU, MATSUO e SEGALL-CORRÊA, 2012; BRAUW et al., 2014; SOUZA e BELIK, 2012; TRALDI, ALMEIDA e FERRANTE, 2012). Entretanto, esses trabalhos não se aprofundam em como os auxílios transformam a realidade dessas famílias, e no Cerrado essa carência de pesquisas se acentua ainda mais. Apesar dos inúmeros estudos e projetos feitos sobre os Kalungas, que tratam da sua relação com o meio ambiente e o território, nenhum deles descreve e analisa a diversidade e as transformações das práticas agrícolas e alimentares desta comunidade

Portanto, o presente trabalho objetiva diminuir a lacuna existente no que diz respeito ao conhecimento sobre as mudanças nas práticas alimentares, além de dar atenção especial às influências das bolsas assistenciais, políticas públicas e turismo, uma vez que estudos indicam que estas são as principais causas das modificações nos sistemas alimentares locais (SILVA e GARAVELLO, 2012; DAMANDO, 2003; TIBURCIO e VALENTE, 2007; SOUZA e BELIK, 2012). Conhecer as particularidades das culturas alimentares locais é um fator importante para discutir as políticas públicas voltadas para a garantia da segurança alimentar destas populações. Além disso, segundo Segall-Correia e Salles-Costa (2008), é importante se pensar em que medida essas políticas públicas ampliam a possibilidade de segurança alimentar das populações atendidas.

Por isso, o presente trabalho pretende descrever como se estruturam os sistemas alimentares Kalungas, na produção, na cozinha e na mesa, com o intuito de compreender as disposições e motivações relacionadas com os processos de transformação e com a permanência da cultura alimentar. A intenção é de que a pesquisa auxilie no entendimento dos fatores que impactam sobre a segurança alimentar da comunidade e a preservação da agrobiodiversidade local. Para isso, foram estabelecidos cinco objetivos específicos, abaixo listados: 
1. Descrever os sistemas alimentares da comunidade, incluindo espécies, procedimentos, preparos e dinâmicas culturais envolvidas;

2. Identificar as alterações e continuidades nos sistemas alimentares locais, a partir da comparação das características atuais e passadas;

3. Compreender as possíveis disposições e motivações relacionadas com as mudanças e permanências nos sistemas alimentares;

4. Verificar o nível atual de segurança alimentar da comunidade a partir da Escala Brasileira de Medida de Insegurança Alimentar (EBIA);

5. Mapear e analisar os fatores que possam dificultar a garantia da segurança alimentar da comunidade e a preservação da agrobiodiversidade local.

Para tratar de tais temas, optou-se por iniciar o trabalho com um apanhado que refletisse a história dos Kalungas, o seu ambiente e a sua cultura. Nesse capítulo (capitulo 1), a partir de uma revisão da literatura, abordam-se questões como escravidão, quilombagem, surgimento das localidades Kalungas, origem do nome, relação com as populações indígenas circundantes, meio ambiente (Cerrado), aspectos socioeconômicos e hábitos culturais da comunidade como um todo.

O capitulo seguinte (capítulo 2) trata da questão metodológica, explicitando a abordagem qualitativa utilizada, baseada nos modelos de etnopesquisa, a partir de ferramentas como a etnografia e a pesquisa ação, além de explicar o EBIA, modelo escolhido para a quantificação da segurança alimentar. O terceiro capítulo trata especificamente do detalhamento do sistema alimentar Kalunga, descrevendo seus principais elementos, como as roças, pastos, quintais, hortas, pomares, o extrativismo e a cozinha em si.

As influências externas são tratadas no capítulo quatro, onde se debatem os programas de transferência condicionada de renda, as cestas básicas e o turismo local, e como esses fatores influenciam os sistemas alimentares e a própria segurança alimentar dessa população. O capítulo cinco trata exclusivamente da segurança alimentar, relatando como as comunidades, a partir de processos não-passivos de adaptação, organizam novas estratégias de diversificação de renda. Estes processos podem, muitas vezes, estar baseados em dinâmicas com múltiplas localidades, como já se identifica em outras comunidades tradicionais (ELOY e LASMAR, 2011).

Diante desse quadro, refletir sobre estratégias sustentáveis para o desenvolvimento social e econômico da comunidade Kalunga, visando um crescimento consciente, que respeite as tradições locais, a qualidade de vida da população e o meio ambiente se tornou 
uma tarefa urgente. O tripé da sustentabilidade (social, ambiental e econômico) pode se construir como alternativa para compreender, pensar e estimular o debate sobre e com pequenas comunidades, como, por exemplo, o quilombo Kalunga. 


\section{CAPÍTULO 1 - OS KALUNGAS: HISTÓRIA, AMBIENTE E CULTURA}

\subsection{ESCRAVIDÃO E QUILOMBAGEM}

Não se sabe ao certo quando o primeiro africano escravizado foi trazido ao território brasileiro, mas a escravidão negra só teve início no continente brasileiro depois de repetidos fracassos na exploração da mão de obra indígena. No princípio os avanços tecnológicos dos colonizadores portugueses, oriundos dos constantes conflitos no território europeu, juntamente com as epidemias causadas pelos germes trazidos do antigo continente, levaram a um rápido extermínio de etnias indígenas inteiras (DIAMOND, 2012). Os que resistiram a essas atrocidades eram poucos e muitas vezes considerados bravos e selvagens demais para trabalharem para os portugueses. Esses dois fatores levaram a uma crescente necessidade de mão-de-obra, que foi suprida pelo braço negro escravizado (GODINHO, 2008).

Estima-se que em 1538 a primeira remessa de escravos, vindo diretamente da Guiné, teria aportado no Brasil. O surgimento desse tráfico de mão-de-obra vinda do continente africano não visava simplesmente fornecer trabalhadores para as plantações coloniais, ele também gerava grandes lucros para a coroa portuguesa, que os aprisionava na costa do continente e os vendia aos senhores de engenho brasileiros (FAUSTO, 1996). Ao contrário do que pensavam e pregavam os traficantes de escravos europeus do século $\mathrm{XVI}$, o continente africano contava com uma estrutura política bem organizada, representada por impérios, confederações tribais e reinos (GODINHO, 2008). Entretanto, a escravidão já era um elemento presente em algumas dessas populações, mesmo que com diferentes dinâmicas, e muitas vezes a captura do escravo se dava pelas mãos de outras etnias locais, que os vendiam em troca de especiarias (MATTOSO, 1990).

Os cativos escravizados eram arrancados de suas terras, afastados de seus familiares, obrigados a se converterem à religião cristã, misturados a integrantes de outras etnias, com outras línguas e costumes e encarcerados em condições precárias, onde muitos não sobreviviam nem à viagem. Eram tratados como mercadorias, objetos vazios que poderiam ser preenchidos com a cultura do colonizador. Dessa forma:

[...] ao perder a liberdade, o africano via-se destituído do que é mais importante na vida de uma pessoa: sua identidade, uma condição que não Ihe toma somente o que possuía antes, mas rouba-lhe, também, o ser que ele era em sua sociedade africana de origem e transforma-o em um cativo totalmente desarmado. (GODINHO, 2008; p.19-20)

Junto com a escravidão surge a resistência à escravidão. A arrogância portuguesa considerava o povo negro mais dócil se comparado às comunidades indígenas encontradas no Brasil, mas isso se devia ao fato deles estarem em um ambiente completamente 
estranho à sua cultura, rodeados por uma língua estranha e plantas e animais exóticos aos seus conhecimentos.

Acreditar que as populações escravizadas aceitavam o cativeiro de forma passiva é ingênuo e subestima a força do povo africano. A resistência negra se deu de diversas formas, algumas mais sutis, como a redução da capacidade produtiva de forma deliberada e a perda das ferramentas de trabalho (CARRIL, 1997), e outras vezes de formas mais incisivas, expressas pelos suicídios, abortos, violência contra os senhores, sabotagem das plantações, guerrilhas e fugas para locais de difícil acesso (AMADO, 2004). Essa última caracterizou uma forma de resistência que no Brasil ficou conhecida como quilombagem.

As fugas para áreas isoladas eram uma alternativa viável e frequentemente adotada pelos escravizados na busca pela liberdade, mas eram vistas pela Coroa Portuguesa e pelos senhores de terras brasileiros como rebeliões que deveriam ser contidas e reprimidas. Entretanto, só em 1740, ao se reportar à realeza lusitana, o Conselho Ultramarino utiliza-se da primeira definição formal de quilombo, que o caracterizava como:

[...] toda habitação de negros fugidos, que passem de cinco, em parte despovoada, ainda que não tenham ranchos levantados e nem se achem pilões neles (CONSELHO ULTRAMARINO, 1740, apud. CHIANCA, 2010, p.19).

Essa definição foi adotada em diversos documentos posteriores, e utilizada para caracterizar e reconhecer um quilombo, perdurando até a abolição da escravidão, no ano de 1888, quando os quilombos foram considerados formalmente extintos. Esse conceito de quilombo, segundo Almeida (2002), carrega ainda as noções legais de fuga, quantidade mínima de fugitivos, isolamento geográfico, moradia habitual (rancho) e capacidade de reprodução e de autoconsumo (pilão). Essas cinco características foram a base de diversas conceituações posteriores a respeito da quilombagem e seus participantes.

Para controlar esse movimento em massa, existia um aparato de repressão violento e uma legislação que fundamentava a criminalização e penalização das fugas (SOUZA, 2008). Os atores dessa força repressora eram os capitães-do-mato e os bandeirantes, que recebiam uma quantia estabelecida de ouro para cada negro fugido recuperado. O resultado disso foi a dizimação quase total de todos os quilombos encontrados (GODINHO, 2008). Muitos daqueles que conseguiram permanecer ocultos existem até os dias atuais, honrando a origem da palavra "quilombo", que vem da cultura bantu e significa acampamento guerreiro, lugar cercado e fortificado (BAIOCCHI, 1999).

Com o fim da escravidão, em 1888, a marginalização desses grupos não foi abrandada, e as populações negras libertas continuaram sem acesso a terras, excluídas da economia 
nacional, a não ser como mão-de-obra barata para os latifúndios e nas cidades. Desde então, as comunidades remanescentes dos quilombos lutam por seus direitos e garantia de território (NEIVA et al., 2008).

\subsection{OS KALUNGAS}

Para se chegar às origens da ocupação negra no estado de Goiás, é preciso primeiro compreender a conjuntura econômica do Brasil no século XVII. Nesse período a Coroa portuguesa passava por um enfraquecimento econômico em decorrência de sucessivas guerras e havia perdido algumas de suas colônias no território asiático (GIUSTINA, 2013). Influenciado por essa situação, o rei Afonso VI ordenou a intensificação das buscas de ouro e pedras preciosas no sertão brasileiro, forma como se referiam às áreas do interior do país ainda não exploradas. Dentre essas áreas se encontrava o que viria a se tornar o estado de Goiás.

Os principais responsáveis por cumprir as ordens reais foram os bandeirantes, que adentravam o território nacional em busca de riquezas, negros fugidos e indígenas. Em 1722, Bartolomeu Bueno, conhecido como o Anhangüera, e João Leite da Silva Ortiz dão inicio a uma incursão que resultou no ciclo minerador conhecido como "Minas dos Goyazes" (BAIOCCHI, 1999). A população do estado de Goiás cresceu rapidamente depois da descoberta das primeiras minas de ouro, passando de vinte mil habitantes, em 1736, para quase o dobro em 1750, e sessenta mil em 1783 (GIUSTINA, 2013).

Enquanto o ouro durou, o processo de povoamento de Goiás se deu de forma rápida e desordenada. Esse crescimento teve como seu principal elemento propulsor o africano na condição de escravo.

O africano foi o elemento principal que possibilitou a colonização do vasto território goiano; com seu trabalho nas minas, abarrotava os cofres da Coroa Portuguesa (Inglaterra, França, etc), permitia abastança dos senhores e deitava na terra as sementes da sobrevivência do homem, implementando a lavoura que mais tarde floresceria. O africano ou afrobrasileiro foi o elemento civilizador [...] (BAIOCCHI, 1999, p. 28).

Junto com as minas movidas pela mão-de-obra escrava, também chegam os quilombos à região goiana. Os relatos de fugas de escravos, africanos e indígenas, em Goiás remetem ao século XVIII. Eles buscavam áreas isoladas e remotas onde pudessem se esconder. Dessa forma a região se torna um local de refúgio e resistência, como explica Palacín (1972):

Se a existência de quilombos implica maus tratos para escravos, em Goiás constituiu um testemunho impressionante, pois não há, praticamente, arraial sem a sombra do seu quilombo (PALACÍN, 1972). 
Com o declínio da mineração muitos senhores saíram da região com seus escravos, mas outros chegavam em busca de sesmarias. Dessa forma, o desenvolvimento do estado continuou a ser sustentando pela mão-de-obra escrava. Entretanto, os vãos e serras de Goiás, juntamente com a distância do litoral e das forças militares coloniais que lá se encontravam, representavam uma utopia de liberdade para os negros e indígenas que fugiam dos maus tratos da escravidão. Em busca de liberdade, escravos fugidos também desciam do Maranhão, Bahia e de Pernambuco (AVELAR e DE PAULA, 2003) à procura de esconderijos onde hoje se localiza o nordeste goiano.

As chapadas dessa região ofereciam grande possibilidade de refúgio, mesmo que o Cerrado tornasse a fuga mais difícil, uma vez que não oferece uma cobertura vegetal densa. Entretanto, caso o foragido conseguisse chegar até as matas que margeavam os cursos d'água, a chance de ser encontrado pelos capitães de mato eram remotas. Outro fator que tornava os quilombos em Goiás tão abundantes e difíceis de rastrear era o fato de serem formados por pequenos agrupamentos familiares. Além disso, suas casas tinham caráter temporário, evitando a permanência prolongada em qualquer localidade, com o intuito de não serem descobertos (GODINHO, 2008).

Muitos desses quilombos nunca foram descobertos pelos seus perseguidores, e permaneceram no mesmo lugar até os dias de hoje. Esse é o mito fundador do conjunto de comunidades do nordeste do atual estado de Goiás, conhecido como Kalungas (AVELAR e DE PAULA, 2003). Esses agrupamentos teriam se formado a partir do século XVIII e seriam compostos por negros que fugiram da escravidão, escravos alforriados que buscavam melhores condições de vida, e homens livres que, após a abolição da escravidão, teriam se refugiado onde não pudessem sofrer abusos.

Ao longo dos anos, alguns relatos escritos a respeito de comunidades negras escondidas nos vãos de Goiás foram feitos, indicando que essas populações já residiam de forma permanente em algumas localidades. O primeiro desses relatos foi feito pelo Sargento Antônio J. Pereira, no dia 16 de abril de 1821. Ele escreveu para o Sargento-Mor Conde de São Félix, dizendo:

[...]passam rumores entre o Arrayal de S. Félix e a Vila de Palma no lugar chamado o estreito existe um caminho muito seguido que vai da margem oriental do rio Maranhão à Serra que da lugar a que pessoas pensem que na sua serra existe índios que se comunica com os índios Canoeiros, persuadidos, outros ao contrário que são negros fugidos que ali habitam, sobre este objetivo deverá um tomar as(...) informações que (mi) farás conhecer pelo correio seguinte (Antônio J. Pereira apud. BAIOCCHI, 1999, p.40). 
Em 1912, Hugo de Carvalho Ramos faz algumas alusões literárias à existência dos negros escondidos nos vãos, mas é apenas em 30 de janeiro de 1962 que o primeiro artigo de jornal cita a existência de comunidades remanescentes próximas ao município de Cavalcante. O artigo, publicado no Jornal de Goiânia, relata as atividades do engenheiro Manuel Passos e mostra que a denominação "Calunga" já era usada para referir-se aos quilombolas da região:

[...] A seguir, o engenheiro Manuel Passos fez a revelação de transcendental relevância para os pesquisadores, notadamente para 0 Centro de Estudos Brasileiros, da Universidade Federal, ora empenhada na coleta, em seu aspecto inédito, de dados referentes à história de Goiás: "Com o nome de Calungueiros ficaram designados os habitantes da região CALUNGA, um pequeno quilombo que se estabeleceu às margens do rio Paranã, constituído dos negros fugidos dos duros trabalhos de mineração das minas de ouro de Arraias, Monte Alegre e Cavalcante. E até hoje continuam os Calungueiros na mais extrema miséria, vivendo quase que exclusivamente da caça e da pesca, sem se aperceberem da evolução do nosso século" (BAIOCCHI, 1999).

Apesar das palavras finais de Manuel Passos, os aquilombados da região se davam conta da existência do mundo externo, e mantinham relações com cidades vizinhas e com indígenas da região há quase três séculos (esse aspecto será tratado com detalhes mais a frente). O contato com os vilarejos próximos era buscado principalmente para o escambo, que tinha por finalidade primeira a aquisição de sal, café, roupas e utensílios domésticos. Entretanto esse contato ocorria de forma esporádica e inconstante, a fim de não expor as famílias escondidas. Pode-se pensar que tal cuidado era desnecessário após 1888, quando a escravidão foi legalmente abolida, mas os negros da região sofriam, até pouco tempo, com ameaças que insinuavam que o perigo da escravidão não havia passado (BAIOCCHI, 1996).

Outra matéria de jornal é escrita em 1970, na folha do povo, por Aziz Cosac. Nela o jornalista constata a existência da comunidade de Contenda, atualmente no município de Monte Alegre, Goiás. Esse relato possui um tom mais poético e idílico ao tratar da comunidade, mas nos mostra algumas particularidades observadas à época, como os tipos de construções e traços culturais. O artigo se chamava "A Arribação dos Calungas", e um dos seus trechos relatava:

Encravada numa cadeia de montanhas num mundo esquecido pela humanidade, a aldeia de Calunga, formada por ex-escravos evadidos da cidade de Arraias no Nordeste goiano, situou-se nos confins daqueles seridós. Mesmo na região, poucas pessoas conhecem a aldeia formada através dos séculos, cujos moradores fazem questão da ausência do homem branco naquelas paragens. [...] E assim, foi formada a hoje aldeia Calunga nos sertões goianos nas imediações de Monte Alegre, recanto do Rio Paranã. As suas arribanas, construídas com palhas de babaçu e outros coqueiros, conservam características e a simplicidade das aldeias da África. 
[...] fizeram daquela aldeia o seu refúgio, criando os seus filhos, casando nos seus rituais e buscando nas lavouras os seus alimentos e no algodão a matéria-prima para os seus enfeites e suas vestes (AZIZ, 1970).

Entre 1970 e 1971, a Universidade Católica de Goiás, por meio da pesquisadora Mari de Nazaré Baiocchi, iniciou o projeto São Domingos, que objetivava planificar e executar pesquisas antropológicas na região nordeste do estado. Entretanto, foi só a partir de 1982, com o Projeto Kalunga - Povo da Terra, que a pesquisadora realmente estabeleceu contato com as comunidades quilombolas. No dia 10 de junho de 1982, com o auxilio de uma pequena equipe e uma tropa de oito animais, Baiocchi chegou à comunidade de Contenda. Apesar da apreensão dos Kalungas com a chegada da equipe de pesquisa, não era a primeira vez que pessoas de fora chegavam até eles. Relatos posteriores coletados pela antropóloga mostraram que já haviam passado por lá um padre (Pe. Pedrocil Guedes), mascates ciganos, tropeiros, um professor, as Superintendências de Campanhas de Saúde Pública (SUCAM) e a Coluna Prestes (BAIOCCHI, 1999).

Em 1983, a fim de obter regularização fundiária para os quilombolas, Baiocchi organizou um mapa da região Kalunga, com as localidades conhecidas até aquele momento. O mesmo foi entregue ao Instituto de Desenvolvimento Agrário de Goiás (IDAGO) com o intuito de motivar a titulação das terras. Entre 1983 e 1988, saíram os primeiros títulos de terras beneficiando as comunidades, entretanto as investidas contrárias por parte dos fazendeiros da região se tornaram mais intensas e violentas (BAIOCCHI, 1999). Em 1988, no centenário da abolição da escravidão, a nova constituição estabeleceu, no artigo nำ6, no Ato das Disposições Constitucionais Transitórias, que:

Aos remanescentes das comunidades de quilombos que estejam ocupando suas terras é reconhecida a propriedade definitiva, devendo o estado emitirIhes os títulos respectivos (BRASIL, 2009).

As tentativas violentas de retirar os Kalungas, no entanto, não cessaram. Muitos são os relatos de intimidações por parte dos fazendeiros da região, onde casas quilombolas foram queimadas e roças tomadas. Em 1989, após um ataque particularmente violento na comunidade de Ribeirão, um advogado do IDAGO foi enviado na tentativa de controlar a situação. Nos dois anos seguintes, entre 1990 e 1991, várias reuniões aconteceram para a elaboração de uma Carta-Denúncia, que foi entregue à Presidência da República. Nesse mesmo período o laudo antropológico atestando se tratar de um território quilombola ficou pronto, levando, no ano de 1991, à criação do Sítio Histórico e Patrimônio Cultural Kalunga, por meio da lei estadual $n^{\circ} 11.409$. Entretanto, o laudo antropológico da Fundação Palmares só ficou pronto no ano de 2003. Em 1997, algumas lideranças locais do quilombo foram levadas à Goiânia para conversar com o Juiz da quinta vara itinerante, como conta Seu Sirilo, liderança da comunidade Engenho II: 
[...] Outra vez foi uma reunião com o Juiz da $5^{\circ}$ ( quinta) vara itinerante em 1997 em Goiânia, onde se tratava das terras e onde ficamos sabendo sobre os nossos direitos de ser quilombolas. Onde se dava por saber que erra uma de nossos antepassados, por isso se dava o direito a nos buscar o nosso direito, porque os nossos antepassados viveu, ali onde dava todo o direito de nos ter a posse da terra a nosso favor, nessa época deu alguns conflitos com os fazendeiros que se dia os donos de todas as terras, e que onde a maioria deles era grileiros e nem tinha um documento que provava o direito daquelas terras que dizia ser donos, dentro desses invasores de terras o Cartório de Cavalcante era um dos maior (COSTA, 2013, p. 36-37).

Em 1999, foi fundada a Associação Quilombo Kalunga, a fim de representar e defender os direitos do povo Kalunga. Nos últimos dez anos as ameaças ao povo Kalunga reduziram significativamente, e até se extinguiram na maioria das localidades, mas a titulação das terras ainda não está concluída e muitas fazendas, que se sobrepõem ao território, não foram desapropriadas, bloqueando boas áreas cultiváveis.

No ano de 2004, um levantamento feito pela Secretaria de Políticas de Promoção da Igualdade Racial (SEPPIR) e pela Fundação Universidade de Brasília (Fubra) estimava que $11 \%$ de todos os domicílios Kalungas se encontravam dentro de áreas invadidas por fazendeiros. Essa situação fundiária era ainda mais crítica no município de Teresina, onde as propriedades invadidas chegavam a representar $17 \%$ das localidades quilombolas (Tabela 1).

Tabela 1 - Distribuição percentual dos domicílios, segundo a situação fundiária (localização em terras invadidas por fazendeiros), por município. Comunidade quilombo Kalunga. (Fonte: SEPPIR-Fubra, 2004)

\begin{tabular}{ccccc}
\hline $\begin{array}{c}\text { Terra Invadida por } \\
\text { Fazendeiro }\end{array}$ & Cavalcante & Teresina & Monte Alegre & Total \\
\hline Não & $86,4 \%$ & $82,4 \%$ & $99,5 \%$ & $86,9 \%$ \\
Sim & $13,6 \%$ & $17,6 \%$ & $0,5 \%$ & $11,1 \%$ \\
\hline
\end{tabular}

Atualmente, mais de vinte comunidades (em 62 localidades) da região nordeste do estado de Goiás, entre os municípios de Cavalcante, Monte Alegre e Teresina de Goiás, se identificam como remanescentes de quilombolas e compõem o que hoje é conhecido como Território Kalunga (Figura 1). Ele possui 237 mil hectares, formando o maior quilombo do Brasil, que abriga mais de duas mil famílias. Entretanto, elas não formam um único quilombo, como é comumente tratado na literatura. Apesar de manterem laços de parentescos entre localidades, suas comunidades têm diferentes origens, surgiram em momentos históricos distintos e possuem ambientes naturais diversos. Essas comunidades podem ser divididas entre cinco grandes "núcleos": Vão do Moleque, Vão das Almas, Ribeirão dos Bois, Contenda e Kalunga (BAIOCCHI, 1996). 


\section{Sítio Histórico Kalunga: Comunidades por Município}
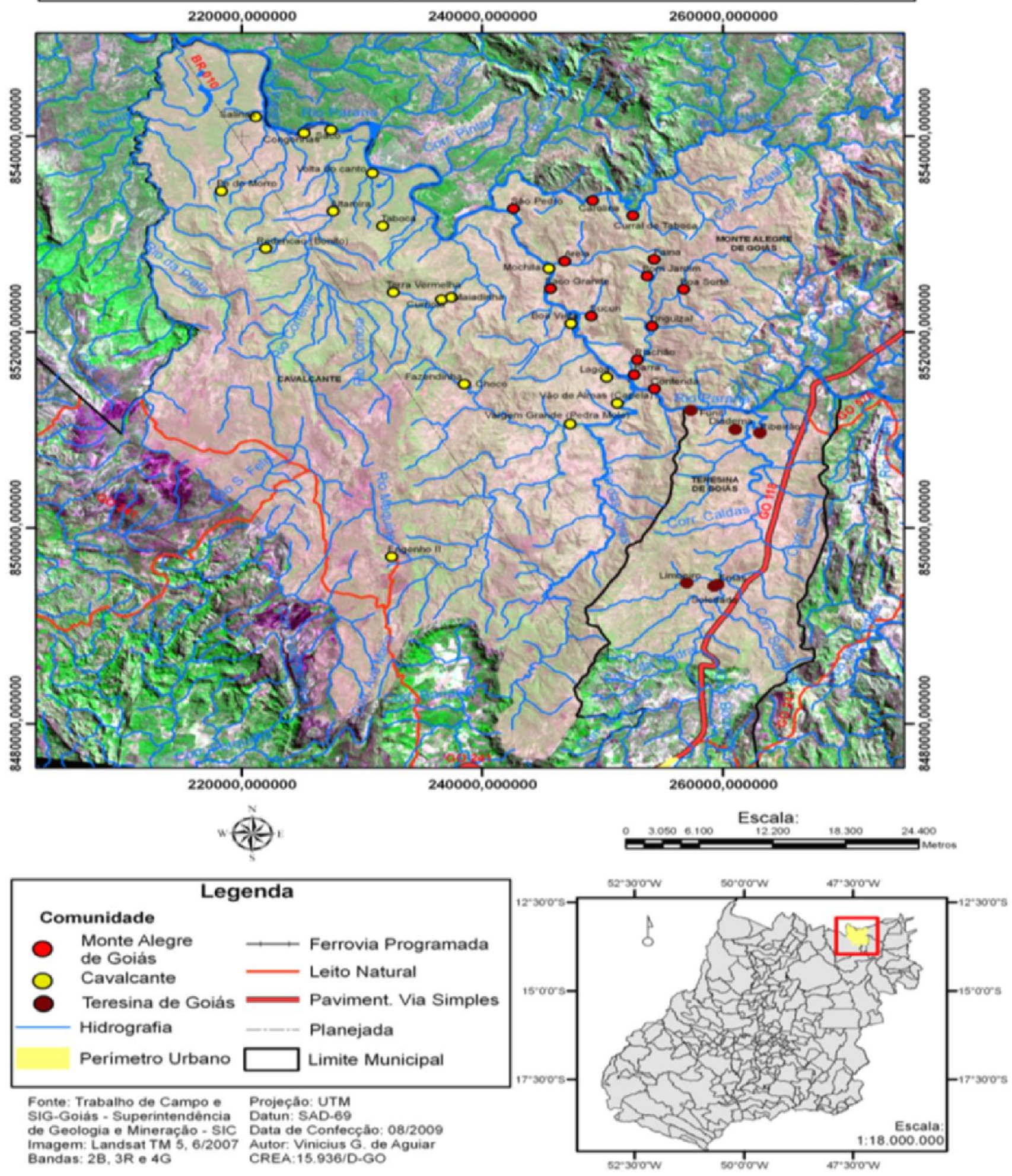

Figura 1 - Comunidades presentes em cada município dentro do Sítio Histórico e Cultural Kalunga. (Fonte: trabalho de campo e SIG -Goiás - Superintendência de Geologia e Mineração - SIC. 2009)

Essas grandes áreas se aproximam mais de um conceito de quilombo unificado, pois apresentam grupos familiares próximos, trocas econômicas e compartilham o mesmo ambiente natural. Contudo, todas elas estão unidas pelo histórico de resistência e 
discriminação que as populações negras sofreram nos últimos séculos e que ainda sofrem no meio rural nos dias de hoje.

\subsection{ORIGEM DO NOME}

A origem da palavra "Kalunga" remete a diferentes fontes, e não existe um consenso. A palavra "calunga" segundo o escritor Alberto da Costa (COSTA apud. BAIOCCHI, 1999) faz referência a uma boneca de madeira, chamada lunga ou calunga. Entretanto, a palavra "kalunga" com k remete a uma palavra mágica do culto bantu, ao "mar divinizado dos angolenses ou ao Deus das profundezas do globo terrestre (LIENHARD, 1998). Já no dialeto quimbundo a palavra é usada para o tratamento de pessoas ilustres, mas também pode significar a morte, o inferno, o mar ou o senhor (BAIOCCHI, 1999).

Para os Kalungas, segundo Baiocchi (1999), a palavra pode ter dois sentidos. Um deles faz alusão a um espaço sagrado, que não pode ser apropriado por uma só família, um lugar para todos, ou um pântano que nunca seca. O segundo significado, mais comumente citado pelos integrantes do território, refere-se a uma árvore da família das Simarubáceas, Simaba ferrugínea, comum na região.

A mesma pesquisadora constatou em seus levantamentos realizados nas cidades vizinhas do território, que as expressões "calunga" ou "calungueiro" eram usadas para se referir aos moradores negros da região dos vãos que vinham à cidade para vender ou trocar sua produção de farinha. A população das cidades acreditava que eles teriam uma única origem, residindo no mesmo lugar e não passando de mais de cinquenta pessoas (BAIOCCHI, 1999). Entretanto, essa forma de tratamento tinha um tom pejorativo, e era usada para diminuir ou debochar dos Kalungas em suas incursões aos municípios vizinhos.

Os moradores da região não tinham por costume se identificar como Kalungas, e costumavam se identificar apenas pela localidade (Contenda, Capela, Engenho, Moleque etc). Foi só a partir do projeto Kalunga - Povo da Terra, das reivindicações ao território quilombola e de todas as atividades relacionadas com isto (como artigos acadêmicos, reportagens na mídia e documentos oficiais), que a comunidade passou a se tratar com o termo unificador "Kalunga". A escolha do nome com $\mathrm{K}$ foi realizada pela antropóloga Baiocchi, na tentativa de desvincular o termo do seu uso pejorativo e de ajudar os moradores da região a se apoderarem de uma identidade forte que remetesse as suas origens africanas.

Ao longo desses mais de trinta anos, a população vem gradativamente se apoderando desse termo, e é cada vez mais comum escutar a comunidade quilombola se tratando por 
"nós, os Kalungas". As diferenciações por localidade permanecem, principalmente entre eles (por exemplo: "Sou Dalila, da comunidade Engenho II"), mas não no intento de se segregarem do grupo, apenas para se distinguirem quanto às origens espaciais. A palavra, que até pouco tempo era desconhecida dos mais velhos no seu contexto de identificação coletiva, é agora usada com força e orgulho pelas lideranças Kalungas. A origem do termo, e seu pouco tempo de uso, não enfraquecem a legitimidade dos preceitos que ele evoca para a comunidade e para seus moradores.

\subsection{QUILOMBOLAS E INDÍGENAS}

A utilização dos vãos do nordeste goiano como refúgio geográfico não foi atividade exclusiva dos negros que fugiam da escravidão. A região também abrigou diversas etnias indígenas. Algumas já residiam lá, e outras, que também buscavam abrigo contra a violência da colonização portuguesa, chegaram ao longo dos séculos passados fugindo das regiões litorâneas.

A ocupação humana no Cerrado remete a aproximadamente 10.000 anos, com grupos de caçadores-coletores que habitavam o Brasil central. Essas comunidades ficaram conhecidas pelo nome de Tradição Itaparica, um grupo completamente adaptado ao ambiente cerratence (GIUSTINA, 2013). Acredita-se que esses paleoíndios deram origem à tradição Una, há 2.500 anos atrás. Uma das hipóteses a respeito dos povos que posteriormente ocuparam a região diz que existiam três linhagens. A primeira seria a linhagem dos Aratu, representada pelos Kaiapó do sul. Os primeiros relatos a respeito dessa etnia foram feitos pelos bandeirantes, e, por se tratar de uma cultura forte e resistente à dominação, foram violentamente combatidos. A segunda linhagem diz respeito ao ramo cultural Urú:

Dentre os grupos relacionados à tradição Urú estão os Goyá, que segundo a historiografia tradicional teriam sido os anfitriões de Anhanguera. Essa etnia deu nome ao estado e teria facilitado a exploração do ouro, tendo em vista o seu conhecimento da região e sua atitude pacífica frente aos bandeirantes. Diante disso, foram exterminados, ainda no início do século XVIII (GIUSTINA, 2013).

Já o terceiro ramo, o Tupi-guarani, está correlacionado com os atuais Avá-canoeiros, que diferentemente dos Kayapó, resistiram tenazmente ao colonizador "não aceitando, em nenhum momento, as propostas de rendição" (OLIVEIRA, 2013, p. 95). Esse grupo se encontrava disperso por toda a bacia do rio Tocantins, e sua origem ainda é uma questão controversa. Alguns historiadores também acreditam que tal etnia, a mais temida da região, teria se formado a partir de descendentes de indígenas do grupo Jê, que fugiram da Bandeira de Bartolomeu Bueno em 1722 e se misturado aos negros aquilombados que se escondiam nas serras e chapadões da região. 
Essa crença, muito comum na tradição goiana, é sustentada por inúmeras evidências do contato frequente que os quilombolas e os índios mantinham. Atualmente, nos registros oficiais, existem apenas três povos indígenas no estado do Goiás; os Avá-canoeiro, os Karajá e os Tapuia (UNGARELLI, 2009). Os Avá-canoeiro, por conta da sua distribuição especial, foram a etnia que manteve maior contato com os Kalunga ao longo dos últimos trezentos anos. Esse grupo é conhecido na região como Povo Invisível, pois fazem questão de não serem vistos. Seu nome é inspirado no meio de transporte mais comumente utilizado por eles, a canoa, na qual sempre desciam os rios da serra de Santana no mês de abril.

Os índios eram muito desconfiados e acreditavam que os negros faziam parte do mundo dos brancos, com o qual não queriam contato. Os negros também temiam os índios e diziam se tratar de índios bravos, que costumavam fazer brincadeiras por "malinezas", conforme diziam os kalungas, como roubar galinha e devolver quatro dias depois, jogar pedras nos animais dos kalungas e nos próprios kalungas (ROCHA, 2009).

Essa relação é fortemente enfatizada por alguns dos membros mais velhos do território, que se identificam com a origem indígena, relatando serem netos ou bisnetos de índias. Essa miscigenação entre indígenas e quilombolas foi particularmente exaltada no material didático produzido pelo MEC, no ano de 2001, onde se coloca que:

[...] pouco a pouco crescia a confiança entre negros e índios. Os índios tinham curiosidade para ver, mesmo que de longe, como viviam os quilombolas. Dizem até que, no tempo antigo, os índios vinham de noite espiar, quase se faziam as rezas e festas, com muita música e dança. Eles ficavam vendo sem serem vistos, participando de longe da alegria geral. De manhã cedo, quando iam embora, um ou outro ficavam pra trás. Saía do bando, entrava no meio dos negros e aceitava uma piga. E tentava conversar, apesar de não entender a língua que ele falava. Isso era no tempo mais antigo, mas, por incrível que pareça, até poucos anos atrás ainda aconteciam histórias assim (BRASIL, 2001).

A pesquisadora Danielle Jatobá, em seu trabalho de 2002 (JATOBA, 2002), demonstra que essa interação também representou uma vantagem adaptativa para os quilombolas refugiados na região, uma vez que significava a aquisição de conhecimentos imprescindíveis sobre o Cerrado e as formas de manejo mais adequadas a esse bioma. Os Kalungas chamavam os índios de compadres ou de tapuias, e essas relações estão vivas até hoje na memória dos mais velhos, representando uma parte importante do imaginário identitário da comunidade. Atualmente os Avá-canoeiro possuem território demarcado entre os municípios de Minaçú e Colinas do sul, com aproximadamente 38.000ha, mas que até o ano de 2000 contava apenas com 16 residentes.

\subsection{MEIO AMBIENTE}

O Cerrado, rico em belezas, biodiversidade e recursos hídricos, é considerado o mais antigo bioma do país e o segundo maior em extensão. Ele se estende através do Distrito 
Federal e dez estados: Goiás, Mato Grosso, Mato Grosso do Sul, Tocantins, Maranhão, Bahia, Piauí, Minas Gerais, São Paulo e Paraná, somando aproximadamente 1.330 municípios (BRASIL, 2014c). O estado do Goiás é composto por 94\% de cerrado. Entretanto o sul apresenta um quadro adiantado de degradação, enquanto o norte possui grandes extensões de áreas preservadas. A região nordeste do estado abriga a microrregião Chapada dos Veadeiros, conhecida por seu alto grau de endemismos e biodiversidade e por isso considerada pelo Ministério do Meio Ambiente como uma região de fundamental importância para a preservação do cerrado (LIMA, 2013). Dentro dessa área de grande riqueza ambiental se encontra o Sítio Histórico e Cultural Kalunga, que guarda não só o modo de vida Kalunga, mas também serras, rios, vãos e matas.

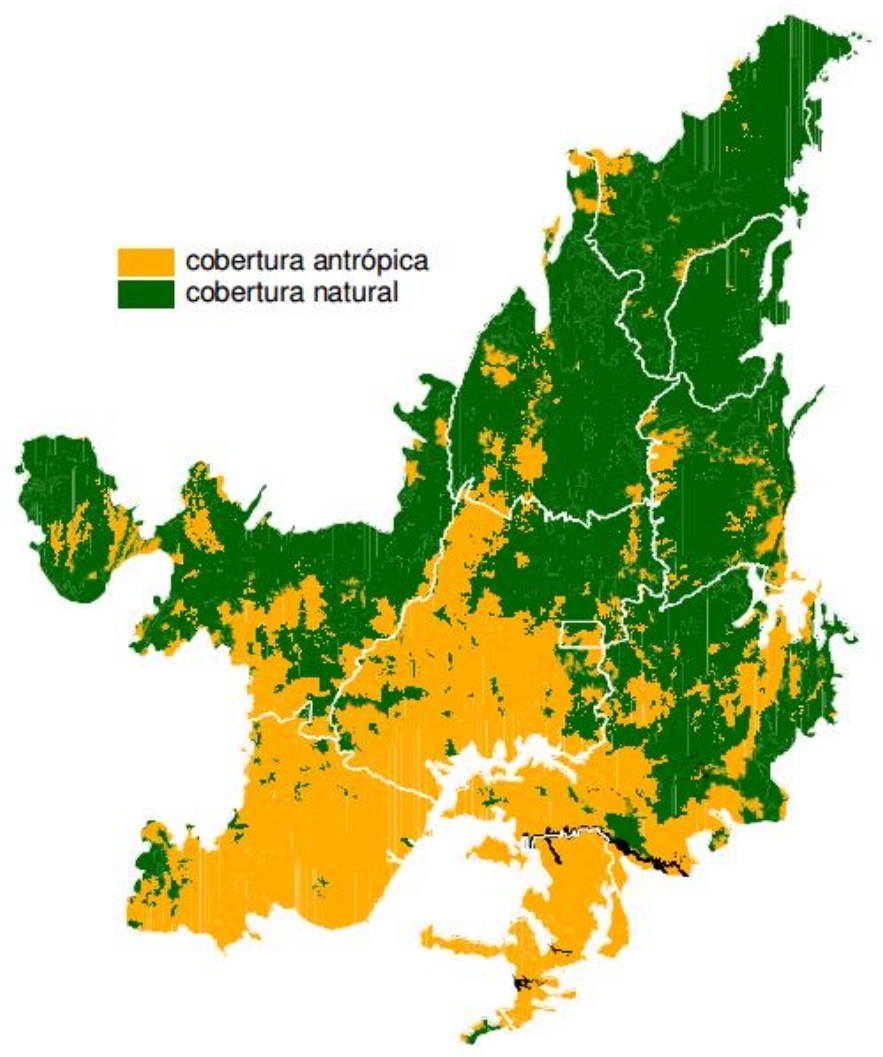

Figura 2 - Extensão do bioma Cerrado, dividido em áreas com cobertura antrópica e cobertura natural. (fonte: BRASIL, 2014c)

O bioma Cerrado representa $24 \%$ do território nacional. É a savana tropical da América do sul e, apesar da ideia equivocada de que seria biologicamente pobre, compõe a savana mais rica do mundo, com $5 \%$ da fauna e flora mundial, motivo que a levou a ser considerada um dos 34 hotspots do mundo (LIMA, 2013). Suas altitudes médias variam de $577 \mathrm{~m}$ a $1676 \mathrm{~m}$, e possui um clima definido como tropical sazonal ou tropical chuvoso, caracterizado por duas estações bem definidas; um inverno seco (maio a setembro) e um verão chuvoso (outubro a abril). Uma particularidade em relação à análise climática kalunga, 
é que eles nomeiam a estação chuvosa de inverno, e a seca de verão, inversamente ao que acontece nas definições oficiais.

A forma de relevo predominante da região são os chapadões, ou chapadas, formações residuais de superfícies antigas que foram desgastadas. Na região do município de Cavalcante, se encontram formações rochosas com mais de 2,5 bilhões de anos. Conhecido como berço das águas, a relevância hidrológica do Cerrado é central, uma vez que abriga partes importantes da Bacia Amazônica, Bacia do rio São Francisco, Bacia Tocantins/Araguaia e Bacia do Paraná (LIMA e SILVA, 2008). Além disso, sua localização estratégica permite que ele interligue quase todos os biomas brasileiros, com exceção dos pampas gaúchos e dos ecossistemas costeiros e marinhos.

O solo predominante do bioma Cerrado é o Latossolo, presente em aproximadamente $46 \%$ de todas as suas áreas. Esse tipo de solo, altamente intemperizado, é marcado pela sua alta permeabilidade, assemelhando-se a um solo arenoso, o que permite 0 desenvolvimento de espécies que necessitam de áreas drenadas. Entretanto, esse tipo de solo é altamente suscetível a erosões e voçorocas quando perde sua cobertura vegetal. $O$ Latossolo, juntamente com uma gama de outros tipos de solo, permite a existência de diversas fitofisionomias, com uma rica variabilidade vegetal. Toda essa biodiversidade pode ser classificada em 11 tipos distintos de cerrado (RIBEIRO e WALTER, 1998), subdivididos em três categorias de formações; florestais, savânicas e campestres.

As formações florestais do Cerrado estão tipicamente associadas aos recursos hídricos da geografia do local, acompanhando cursos de água, mas podem ocorrer desvinculadas dos recursos hídricos em solos mais ricos. Essa categoria possui quatro subdivisões: a mata ciliar, a mata de galeria, mata seca e cerradão. Já os ecossistemas savânicos e campestres, são tipicamente associados ao cerrado, e espalham-se de acordo com variáveis climáticas e pedológicas. O tipo de solo, a escassez de água em grande parte do ano, e a passagem do fogo são fatores que delimitam as fitofisionomias cerratences.

Pesquisas em ecologia mostram que o Cerrado é um mosaico de fisionomias moldadas pela diversidade de regimes de fogo (Miranda, 2010). A sua supressão ou a sua superutilização tem efeitos negativos sobre o ecossitema, pois milhares de anos de coevolução entre o fogo e o cerrado o tornaram dependente da queima esporádica em diversos processos ecológicos, como a quebra de dormência em sementes. Dentre as formações savânicas estão o cerrado sentido restrito, o parque de cerrado, o palmeiral e as veredas, compostas pela presença predominante de buritis. As fitofisionomias campestres são apenas três, o campo sujo, o campo rupestre e o campo limpo. 
A abundância desse bioma é responsável, no Brasil, por $50 \%$ das espécies de aves, $45 \%$ dos peixes, $40 \%$ dos mamíferos e $38 \%$ dos répteis (AGUIAR e CAMARGO, 2004), além de mais de 10.000 mil espécies vegetais catalogadas, de acordo com a Conservation Internacional $(\mathrm{Cl})$. O Cerrado, sozinho, representa mais de $30 \%$ da diversidade biológica brasileira. Pela sua grande biodiversidade, ele foi considerado uma área prioritária de conservação, e vem chamando a atenção de instituições e pesquisadores de dentro e fora do país.

Entretanto, o Cerrado tem sido constantemente ameaçado pelo avanço da fronteira agrícola. A abertura de novas áreas de plantio e de pastoreio são as maiores causadoras de desmatamento neste bioma. A expansão do agronegócio, nos últimos quarenta anos, devido aos avanços tecnológicos no campo dos cultivos adaptados ao clima semiárido, principalmente nas culturas de milho e soja, aliada à urbanização e ao crescimento econômico, tem causado impactos alarmantes em relação a esse ecossistema.

Estima-se que atualmente só restem cerca de $20 \%$ da sua cobertura vegetal original ou pouco perturbada, e alguns estudos mais pessimistas já apontam o completo desaparecimento dele até o ano de 2030 (MYER, MITTERMEIER, et al., 2000). No estado do Goiás o nível de degradação ambiental chega a 75\%, causados principalmente pela atividade agropecuária (Figura 3). Os $25 \%$ restantes abrigam diferentes estados de áreas conservadas, e incluem os $4,5 \%$ do território protegidos por unidades de conservação (UNGARELLI, 2009).

Visando reduzir esse tipo de dano ambiental, em 1974, o Brasil aderiu ao Programa Man and the Biosphere (MaB). A partir dele foram criadas seis reservas da biosfera no território nacional, que abrigam importantes microrregiões de biomas ameaçados. Essas áreas devem cumprir três funções primordiais; contribuir para a conservação da biodiversidade, fomentar o desenvolvimento sustentável e promover condições para o desenvolvimento de projetos que produzam e difundam o conhecimento focado para a conservação e para o desenvolvimento sustentável. Uma dessas áreas é a Reserva da Biosfera Cerrado (RBC) (Figura 4), que foi dividida em três fases: fase I - Distrito Federal, fase II - estado do Goiás, fase III - estados do Tocantins, do Maranhão e Piauí (GIUSTINA, 2013). A fase II, representada pelo estado de Goiás, que é quase inteiramente formado pelo bioma Cerrado, iniciou-se em outubro de 2000, mas está com suas atividades paradas desde 2006. 

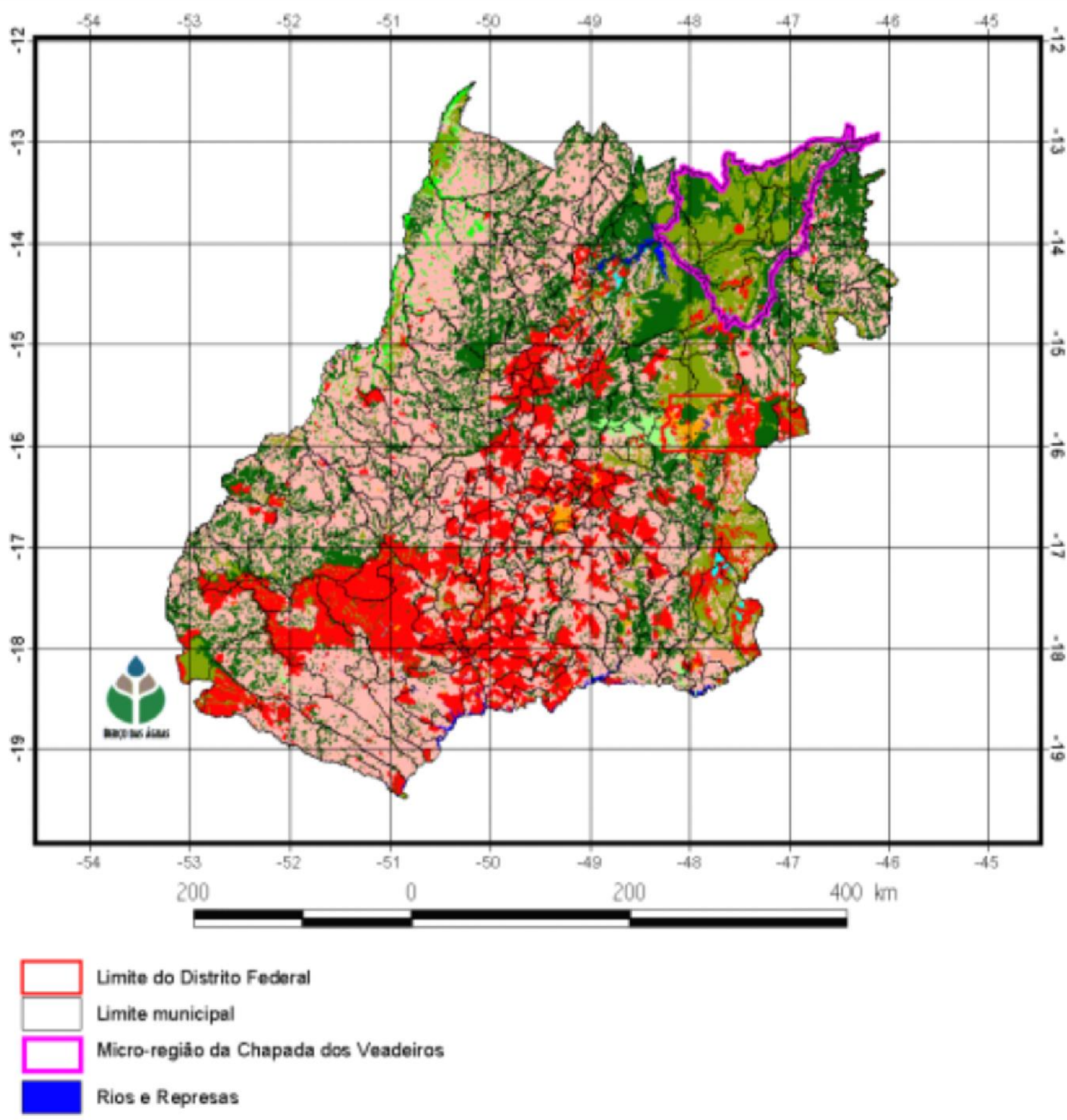

Limite do Distrito Foderal

Limite municipal

Micro-regiáo da Chapada dos Veadeiras

Rios e Represas

Uso do Solo e Cobertura Vegetal

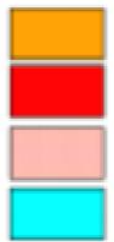

Áreas Urbanas e Núcleos Rurais

Agriculturas Anual e lrrigada

Pastagens Permanentes e Agricultura de Pequeno Porte

Reflorestamento

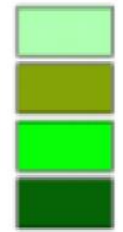

Savanas Gramineas

Savanas Parque

Matas Ciliares e de Galeria

Florestas e Savanas Afborizadas

- Parque Natural Municipal Levapés

Figura 3 - Uso do solo e cobertura vegetal no estado do Goiás, no ano 2000. (Fonte: Ungarelli, 2009) 


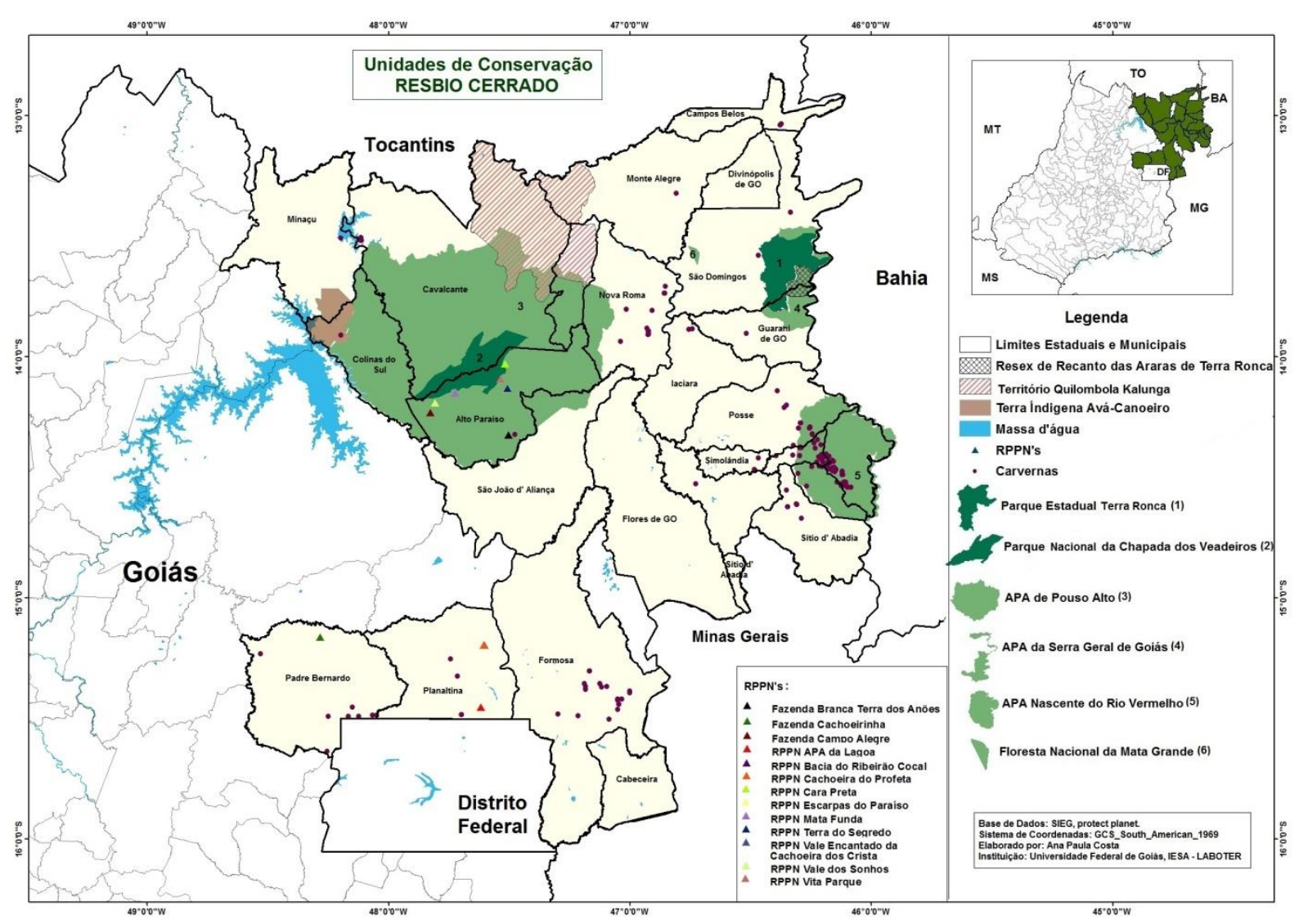

Figura 4 - Unidades de Conservação dentro da RESBIO Cerrado (Fonte: LABOTER-UFG).

Aliado à gestão biorregional das reservas da biosfera, aos projetos de corredores ecológicos e aos programas de gestão em mosaicos, o Ministério do Meio Ambiente (MMA), no ano de 2009, definiu uma hierarquização de áreas prioritárias para a conservação da biodiversidade no país inteiro. Para isso se baseou em critérios de representatividade, persistência e vulnerabilidade (GIUSTINA, 2013). Essas áreas podem ser vistas na Figura 5, que ainda destaca a quantidade de vegetação natural em cada área estabelecida como importante para preservação.

Ao sobrepormos a Figura 3 e a Figura 5, fica clara a relevância biológica do nordeste goiano, uma vez que ele abriga a maior parte do cerrado preservado do estado e ainda está quase completamente definido dentro das áreas prioritárias de conservação. A microrregião da Chapada dos Veadeiros, com cerca de $21.000 \mathrm{~km}^{2}$, conta com oito municípios (Alto Paraíso, São João da Aliança, Teresina de Goiás, Nova Roma, Monte Alegre de Goiás, Campos Belos, Colinas do Sul e Cavalcante), todos eles dentro de áreas prioritárias, segundo o MMA, e com alto índice de vegetação natural presente. 


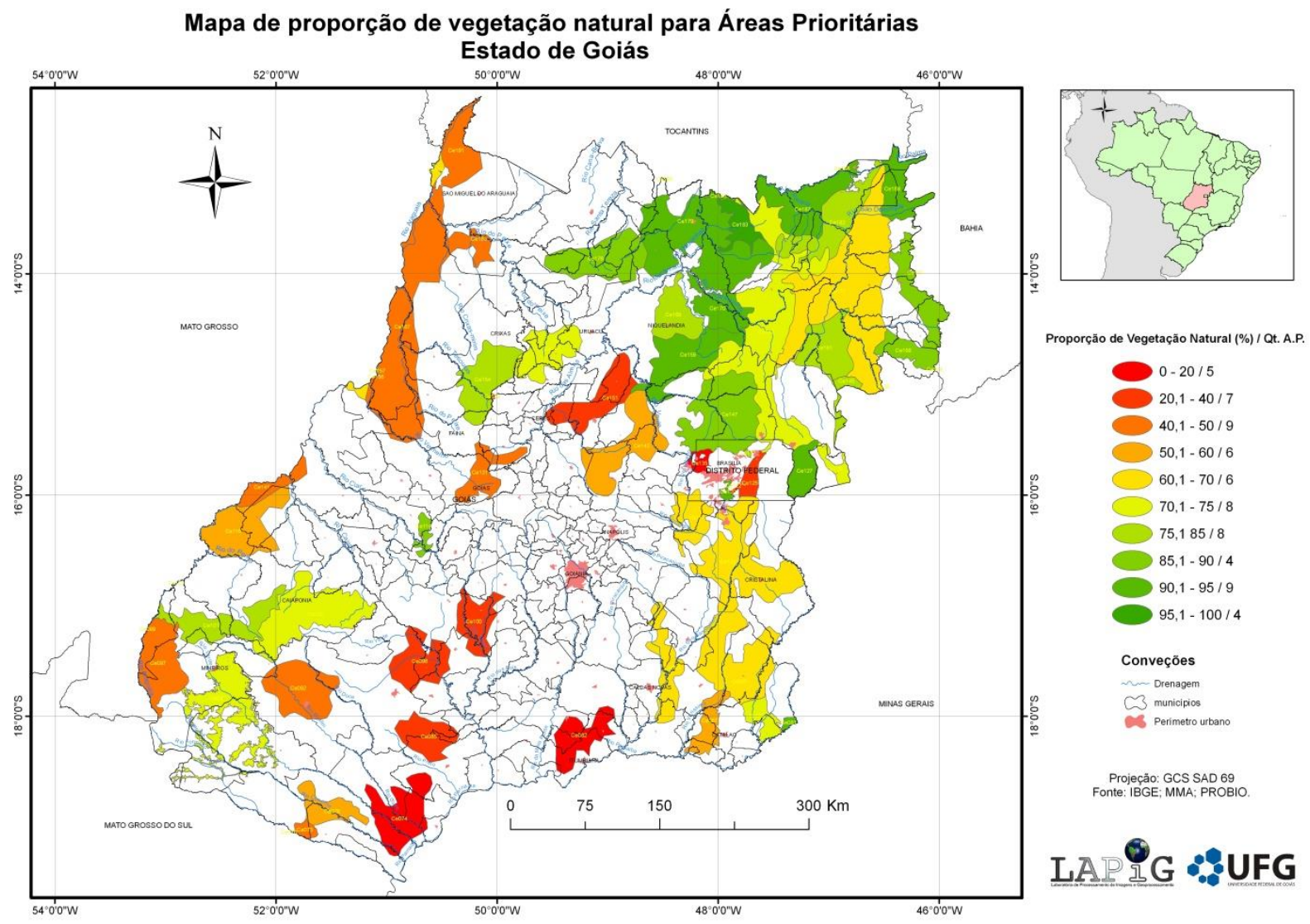

Figura 5 - Proporção de vegetação natural nas áreas prioritárias do estado do Goiás. (Fonte: LAPIG - UFG /dados do IBGE, MMA e PROBIO)

Outro dado preocupante em relação ao Cerrado é o alto índice de fragmentação das áreas preservadas, onde a maioria dos fragmentos encontrados é de pequeno porte (FELIZOLA e FELFILI, 2006). Isso acarreta uma maior fragilidade das áreas remanescentes nativas, em decorrência da sensibilização típica causada pelo efeito de borda, que aumenta de forma inversa ao tamanho do fragmento. Esse dado alerta para a importância das ações integradas de gestão quando se trata de preservação, já que o tamanho e a forma do território tem relação direta com a qualidade e efetividade da conservação realizada.

Dito isso, o Território Kalunga, localizado no coração dessas áreas prioritárias, composto por grandes extensões de cerrado preservado, se faz um interessante foco de ações voltadas para o desenvolvimento de atividades sustentáveis. Ao se caracterizar como terra quilombola, de acordo com o Plano Estratégico Nacional de Áreas Protegidas (PENAP), criado pelo decreto 5.758, de 13 de abril de 2006, a área referida se enquadra no perfil de área protegida, mas permanece sobre o domínio das comunidades, o que permite o exercício da agricultura, pecuária, caça, pesca, retirada de madeira e mineração.

O direito à terra das comunidades remanescentes de quilombolas é inegável e inalienável, assim como aquele concedido as populações indígenas em seus territórios, não 
existindo sentido em exigir deles a adoção de um comportamento mais "harmonioso" em relação à natureza do que o resto da sociedade brasileira adota (DRUMMOND, 2014). Entretanto, o conhecimento local desenvolvido ao longo de várias gerações junto ao ambiente natural onde estão inseridos, muitas vezes permite a esses grupos que exerçam suas atividades de maneira sustentável, com o mínimo de impacto e preservando o máximo de área possível, uma vez que visam principalmente a subsistência e não o agronegócio.

Além disso, os saberes Kalungas, de ontem e de hoje, carregam em si diferentes formas de consciência ecológica. No passado ela adivinha da necessidade direta de conservação do meio para a sobrevivência dos grupos refugiados. Atualmente, ela é fruto de um diálogo sadio entre conhecimentos científicos difundidos e saberes ancestrais transferidos por gerações. O kalunga e pesquisador Vilmar Souza Costa, atual presidente da Associação Quilombo Kalunga (AQK), exemplifica isso em um trecho do seu trabalho, onde comenta que:

Os primeiros quilombolas tiveram que aprender a sobreviver na região da Chapada para poderem continuar livres. Essa adaptação deu origem à cultura de envolvimento e preservação da natureza que temos hoje. Há muitos tempos atrás, eram nós que dependíamos da natureza para sobreviver. Hoje, é a natureza que também passou a depender do povo Kalunga para sua preservação, porque é aqui que se conservam diversas espécies de animais ameaçados de extinção [...] (COSTA, 2013, p. 23).

\subsection{ASPECTOS SOCIOECONÔMICOS}

Apesar de sua grande beleza cênica e abundância de recursos hídricos, que atraem turistas de todo o Brasil e de várias partes do mundo, o nordeste goiano é a região mais pobre do estado. Nos três municípios que dividem o território Kalunga, as taxas de extrema pobreza (renda familiar mensal inferior a $\mathrm{R} \$ 70$ por pessoa) entre a população total ficam na média de $17 \%$, chegando a alcançar $29,7 \%$ no munícipio de Cavalcante. Esse quadro se agrava na zona rural, onde todos os municípios apresentam situações críticas; Teresina possui $34,35 \%$ da população rural nessa condição, Monte Alegra 33,85\% e Cavalcante $39,81 \%$.

Assim como na maior parte do território nacional, o êxodo rural continua a ser uma realidade. A falta de condições mínimas de infraestrutura, saúde e educação dificultam a permanência das famílias no campo, que buscam, nas cidades, melhores condições. Os residentes em zona urbana cresceram em todos os três municípios, saltando de $39,95 \%$ no ano de 2000 para 50,49\% em 2010, na localidade de Cavalcante, de 39,85\% para 40,93\% em Monte alegre, e de 68,01\% para 70,76\% em Teresina (IBGE, 2010). 
Essa significativa migração rumo às cidades dá indícios da situação precária que as famílias rurais desses três municípios enfrentam. As comunidades Kalungas não são diferentes nesse aspecto. Entretanto, elas apresentam diferentes estados de desenvolvimento. Algumas, como Engenho II e Emas, possuem luz elétrica, escolas, casa de alvenaria e fácil acesso aos centros urbanos por meio de estradas. No entanto outros núcleos mais afastados, como os do Vão das Almas e do Vão do Moleque, não possuem sequer energia elétrica ( $80 \%$ de todo o território) e são de difícil acesso.

No ano de 1991, na ocasião da criação do Sítio Histórico, o Instituto de Terras do Estado de Goiás (IDAGO) realizou um levantamento socioeconômico onde foram cadastrados 3.699 habitantes dentro do território Kalunga, sendo que 3.194 foram considerados quilombolas e 505 não (critérios não especificados). Em 2004, a SEPPIR e a Fubra realizaram outra coleta de dados, onde foram contabilizadas 958 famílias, divididas em 884 domicílios, totalizando 3.752 moradores quilombolas (SEPPIR-FUBRA, 2004).

Atualmente, segundo o Ministério do Desenvolvimento Social e Combate a Fome (MDS), 1.939 famílias quilombolas estão inscritas no cadastro único dos municípios de Cavalcante, Monte Alegre e Teresina. Esse cadastro provê dados individualizados, atualizados no máximo a cada dois anos, sobre os brasileiros com renda familiar de até meio salário mínimo per capita, permitindo saber quem são, onde moram, o perfil de cada um dos membros das famílias e as características dos seus domicílios. As informações do MDS (BRASIL, 2014b) foram usadas como base de dados, mesmo que a estimativa de famílias cadastradas seja de apenas $94,6 \%$ do total, em decorrência da falta de outras fontes atuais e oficiais para a obtenção de tais dados.

Tabela 2 - Número de famílias e de habitantes quilombolas Kalungas estimados nos anos de 1991, 2004 e 2014 (fontes: IDAGO, 1991; SEPPIR-Fubra, 2004; Costa, 2013).

\begin{tabular}{ccc}
\hline Ano & Famílias & Habitantes \\
\hline 1991 & - & 3.194 \\
2004 & 958 & 3.752 \\
2014 & 1.939 & $\sim 10.000$ \\
\hline
\end{tabular}

Esse salto numérico que ocorre entre os dados de 2004 e de 2014, não está apenas associado com o crescimento demográfico dessa população. Ele também indica uma nova forma de contabilizar as famílias Kalungas, considerando não apenas aquelas que estão integralmente vivendo dentro do território, mas também aquelas que permanecem períodos parciais ou integrais no perímetro urbano das cidades próximas. Agregado a isso, também 
se estima que o número de auto-identificações Kalungas tenha crescido nos últimos anos, acompanhando o movimento de empoderamento sobre sua identidade que a comunidade quilombola vem vivendo.

Dessas quase duas mil famílias, 1.271 recebem os benefícios do programa de transferência condicionada de renda, o Bolsa Família. Só no município de Cavalcante, os Kalungas representam mais de 50\% dos beneficiados, com 641 famílias contempladas. Os valores médios dos auxílios variam de $R \$ 180,00$ a $R \$ 222,00$ mensais. A distribuição da população quilombola dentro do território se dá de forma desigual entre os municípios, assim como a distribuição de terras. A maior parte das famílias reside na parcela do território que se situa dentro de Cavalcante, representando $56 \%$ do total delas (Figura 6). Em segundo lugar está Monte Alegre, com 28\%, e por último Teresina, com 16\% do total de núcleos familiares Kalungas.

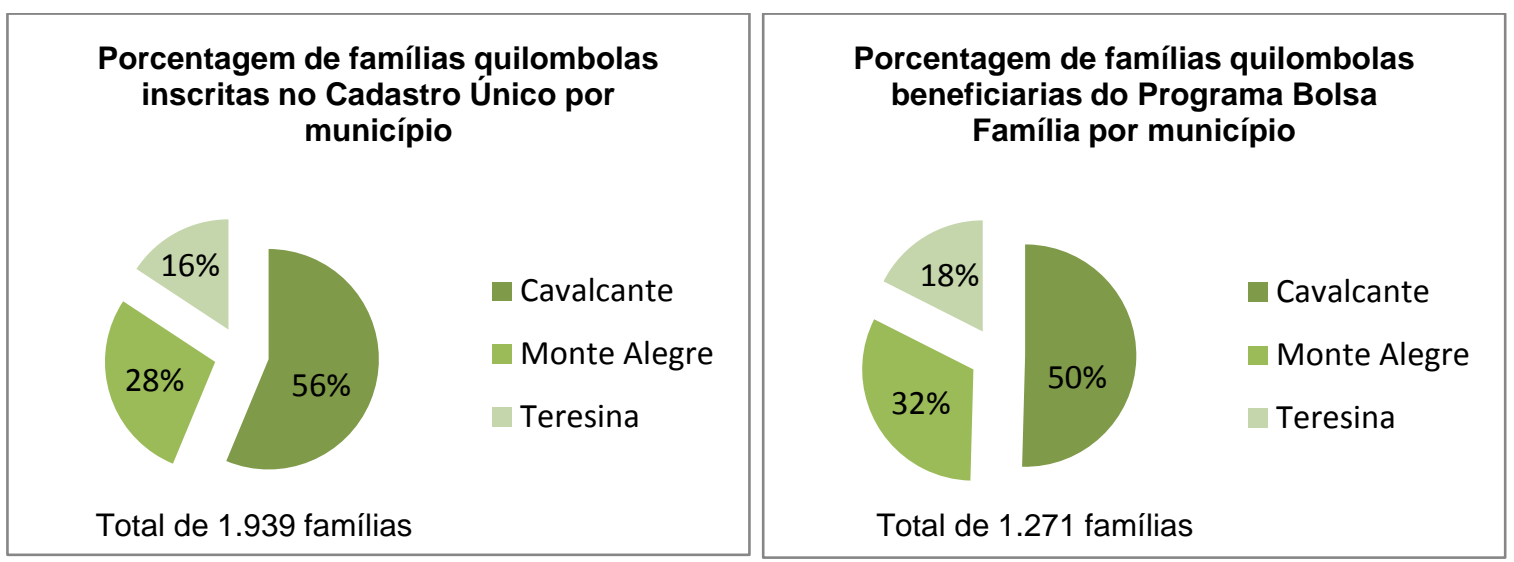

Figura 6 - Porcentagem de famílias quilombolas Kalungas inscritas no cadastro único e participantes do Bolsa Família entre os municípios de Monte Alegre, Teresina e Cavalcante, do Estado do Goiás, de acordo com os dados do MDS de 2014.

De acordo com o Censo do IBGE de 2010, em relação à auto-declaração de cor, os municípios são predominantemente compostos por pardos e negros (Figura 7), que chegam a representar, se somados, $82 \%$ da população de Monte Alegre. Entretanto, o município com a maior porcentagem de indivíduos que se declararam negros, foi Cavalcante com $26 \%$, que também abriga o maior número de famílias quilombolas, segundo o MDS (BRASIL, 2014b).

Esses dados indicam uma continuidade histórica da dinâmica social que se iniciou no século XVIII, com a chegada do trabalho escravo na região de Cavalcante, antes detentora de toda a área dos três municípios anteriormente citados. Dados de um censo realizado por Luiz da Cunha Menezes de Mello e Castro, no ano de 1779, na capitania de Goiáz, criavam um mapa da população a partir de uma distinção de classe entre brancos, pretos e pardos (VILA BOA apud. GODINHO, 2008). 

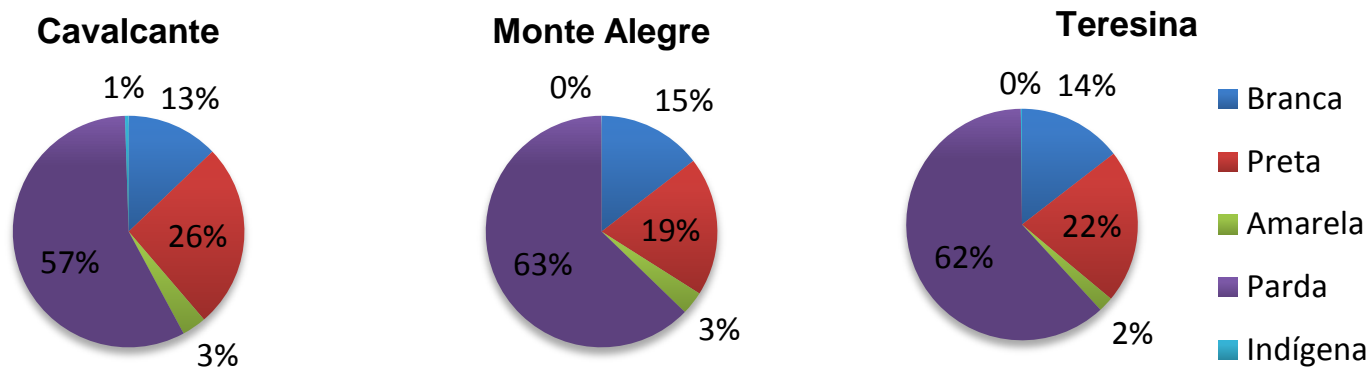

Figura 7 - Declaração de cor, em porcentagem, nos municípios de Cavalcante, Monte Alegre e Teresina, no Goiás, de acordo com os dados levantados pelo censo do IBGE, no ano de 2010.

As informações contidas nesse ofício, quando comparadas aos dados atuais do IBGE, mostram que o movimento da quilombagem na região foi significativo para a formação das comunidades negras de hoje em dia. Ao se somar as porcentagens de negros e pardos em ambos os gráficos (Figura 8), obtém-se números muito semelhantes (89\% em 1779 e 83\% em 2010), que indicam que mais de 230 anos serviram para aumentar a população local em mais de doze vezes, mas não alteraram o seu perfil étnico de forma significativa.

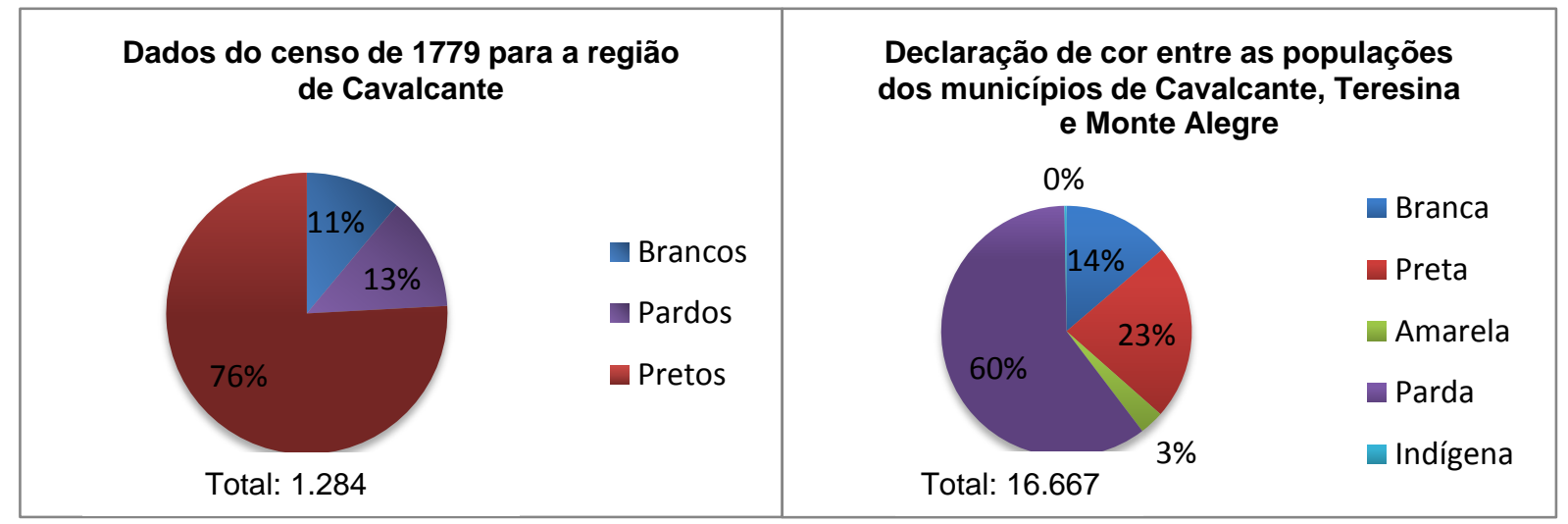

Figura 8 - Comparação entre dados relacionados à cor da população na região de Cavalcante, no ano de 1779 e no de 2010, baseados nos dados do ofício de Luiz da Cunha Menezes de Mello e Castro (GODINHO, 2008, p. 30) e dados do censo do IBGE de 2010.

Outro perfil que parece não ter sido alterado na região ao longo dos últimos séculos é o socioeconômico. Levando em consideração que as famílias registradas no Cadastro Único do MDS precisam se enquadrar no perfil de renda de até meio salário mínimo per capita, ao olharmos para as porcentagens dos diferentes grupos familiares cadastradas, vemos que $96,4 \%$ das famílias são quilombolas. Ou seja, quase cem por cento das famílias dos três municípios que se enquadram no perfil de pobreza são compostas por negros ou pardos (partindo-se do pressuposto que as famílias quilombolas não se declarem como brancas, amarelas ou indígenas) (Figura 9). 
Esses dados podem indicar uma manutenção da estrutura de classe herdada do período colonial, quando a população negra era apenas utilizada como mão-de-obra. Como já citado anteriormente, o final da escravidão não significou a inclusão dos negros na economia nacional, uma vez que a eles não foi concedido legalmente o direito à terra. Essa, e outras injustiças sociais se propagaram ao longo dos anos e, podem ser observadas por dados como esses, que mostram a predominância de descendentes de negros escravizados entre os grupos mais vulneráveis da sociedade brasileira.

Porcentagem dos grupos de populações tradicionais ou específicas registradas no Cadastro Único entre os municípios de Cavalcante, Teresina e Monte Alegre

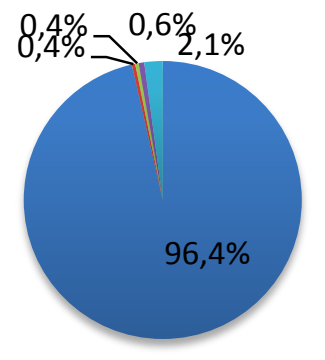

Quilombolas

口 Indigenas

Ciganos

- Resgatadas do Trabalho Escravo

Reforma agrária

Figura 9 - Porcentagem dos grupos de populações tradicionais ou específicas registradas no cadastro único do MDS, no ano de 2014, entre os municípios de Cavalcante, Teresina e Monte Alegre.

Os perfis produtivos dos três municípios estudados são bem diversos, mas em todos os casos, os principais componentes do produto interno bruto ficam divididos entre o setor de serviços, indústria e agropecuária. Contudo, o município de Cavalcante possui uma particularidade, pois aproximadamente $80 \%$ do PIB são oriundos do setor da indústria (Figura 10). Isso se deve ao fato do município, além de abrigar diversos polos mineradores, também contar com os royalties referente à Usina Cana Brava. Esse município, com 6.953,646 km², no ano de 2010 gerou 186 milhões de PIB, quase três vezes mais do que Monte Alegre e nove vezes mais que Teresina.

Entretanto, basta uma visita à região para se notar os problemas de gestão pública, que fazem com que esse dinheiro não chegue até a população, gerando um Índice de Desenvolvimento Humano do Município (IDHM) de apenas 0,584 , o segundo pior do estado. Cerca de $30 \%$, dos quase dez mil moradores do município, estão dentro da faixa da extrema pobreza, dos quais $64,8 \%$ se encontram no meio rural. Em 2006, Cavalcante contava com 957 agricultores familiares, que correspondiam a $78 \%$ dos produtores. Juntos eles contribuíram com $46 \%$ da produção agropecuária municipal, possuindo acesso a somente $19 \%$ das áreas produtivas.

Monte Alegre, com um território de $3.119 \mathrm{~km}^{2}$, possui um perfil produtivo diferente. Suas fontes de renda principais são o setor de serviços e a agricultura. Em 2010, o 
município possuía um o PIB de 50,9 milhões e contava com 7.730 habitantes, mas 41,48\% deles se encontravam na extrema pobreza. Já o município de Teresina possui um território de $774,635 \mathrm{~km}^{2}$, e , segundo o censo de 2010, contava com uma população de 3.016 habitantes, mas com a peculiaridade de $70,76 \%$ deles se encontrarem na zona urbana. Neste ano, o PIB foi de 16,1 milhões, dois quais $69,9 \%$ foram gerados pelo setor de serviços. A taxa de pobreza alcançou $61,44 \%$ dos moradores, sendo a mais alta entre os três municípios analisados.

O município de Cavalcante tem experimentado um significativo aumento da atividade turística nos últimos anos (UNGARELLI, 2009). A região do Sítio Histórico e Cultural Kalunga (SHCK) conta com mais de 120 cachoeiras catalogadas, mirantes, cavernas e diversos outros atrativos naturais que atraem visitantes de todo Brasil em busca do ecoturismo e do turismo de aventura. O município abriga, além da maior parte do SHCK, dois terços do Parque Nacional e diversas reservas particulares do Património Natural. Agregado às maravilhas naturais, os Kalungas também possuem uma rica história que atrai o turismo cultural, com suas folias, festas e romarias. Infelizmente ainda não existem dados formais a respeito da renda gerada pelo turismo dentro do sítio, mas algumas outras informações ajudam a traçar o perfil turístico da comunidade.

Em 2011 a Fundação Banco do Brasil (FBB) encomendou um diagnóstico turístico de três localidades Kalungas: Vão de Almas, Vão do Moleque e Engenho II (CAMPOS, 2011). O estudo levantou, dentre outras informações, as condições dessas comunidades em relação à infraestrutura presente nas comunidades. Em relação aos sistemas de comunicação, apenas Engenho II possui sinal de celular, antena parabólica e laboratório de informática com internet. Todas as outras localidades carecem de telefonia, agências postais, acesso a sinal de televisão e internet.

No que diz respeito à segurança, todas as comunidades são iguais, não possuindo posto de polícia, corpo de bombeiros ou grupo de busca e salvamento. O serviço médicohospitalar também é nulo, e as famílias não contam com postos de saúde, hospitais, pronto socorros, dentistas ou maternidades, com exceção de um posto de saúde instalado recentemente no Engenho II, mas que não apresenta regularidade de funcionamento. Esta comunidade também é a única com ensino médio, todas as outras só possuem escolas de nível fundamental. 


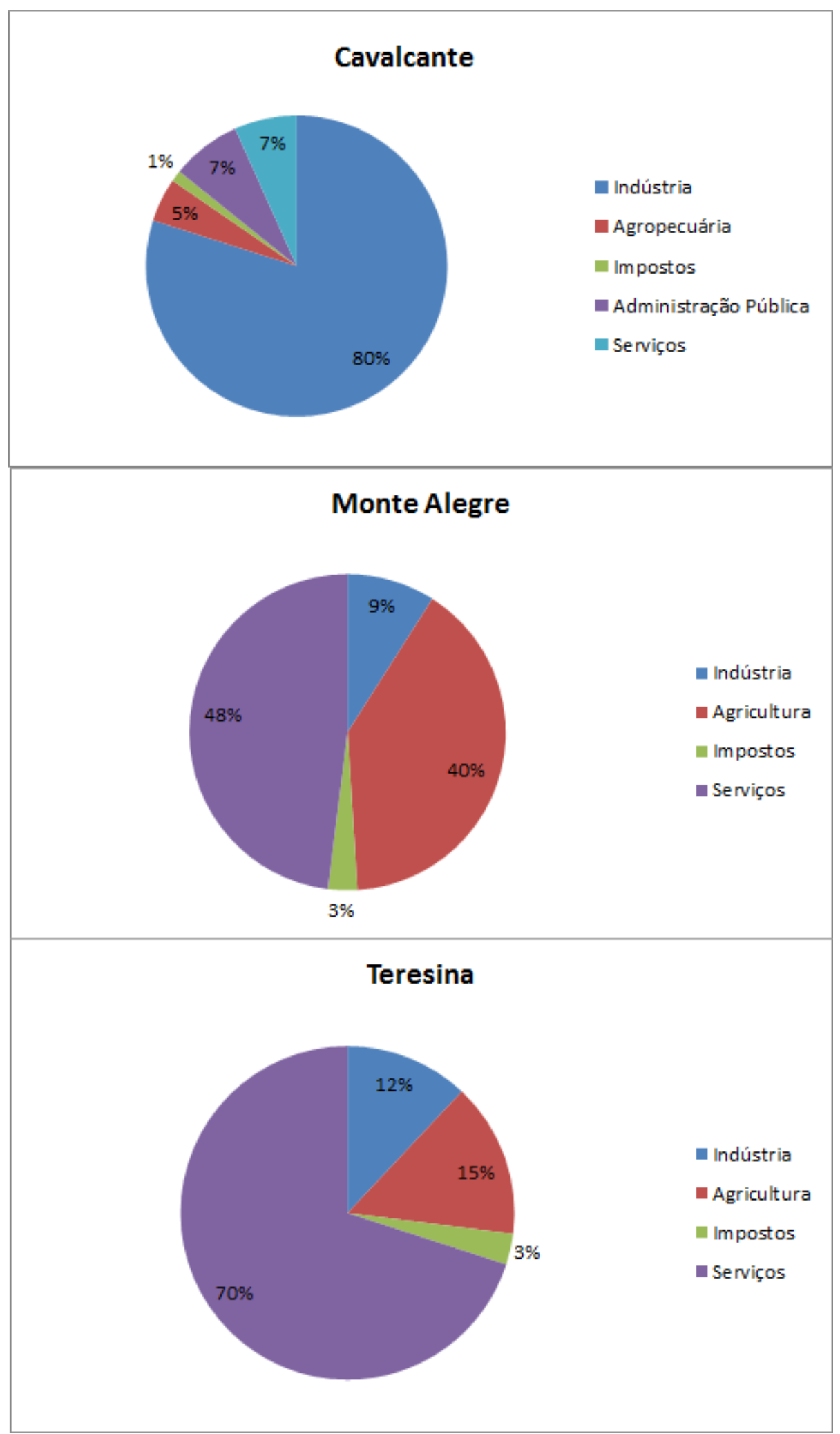

Figura 10 - Participação dos setores econômicos no PIB dos municípios de Cavalcante, Monte Alegre e Teresina de Goiás, respectivamente. (fonte: IBGE 2010) 
A fim de proporcionar uma melhor educação aos seus filhos, as famílias muitas vezes se mudam para a cidade (total ou parcialmente) no período escolar, ou mandam as crianças em idade escolar para viverem na casa de parentes ou compadres da zona urbana. Esse hábito é comum nas famílias rurais de várias partes do Brasil (ELOY e BRONDIZIO, 2014), e caracteriza uma dinâmica espacial típica das moradias Kalungas, que será tratada mais adiante. Outro problema, decorrente da falta de estrutura educacional no território, é a discriminação que os jovens quilombolas sofriam (e ainda sofrem) ao frequentarem as escolas urbanas. Isso leva, muitas vezes, ao desinteresse, falta de assiduidade e abandono do ensino formal por parte dessas crianças.

Nenhuma das comunidades possui rede de esgoto, rede de água potável ou tratamento adequado dos resíduos. No que diz respeito à hospedagem e atendimento aos turistas, apenas a comunidade do Engenho II possui quartos para aluguel, área de camping, Centro de Atendimento ao Turista (CAT) e restaurantes de comida caseira.

Ainda de acordo com a pesquisa da FBB, a maioria dos turistas que procuram o Sítio Kalunga é oriunda do estado do Goiás ou do Distrito Federal, tem renda acima de cinco salários mínimos e gasta diariamente, no local, valores entre $R \$ 51,00$ e $R \$ 150,00$. O perfil predominante dos grupos de visitantes é de amigos ou casais, mas os passeios familiares também são observados. Quando questionados a respeito de produtos ou serviços que gostariam de adquirir durante a visita, mas que não tiveram acesso, a maioria dos turistas respondeu que estariam interessados em produtos da agricultura familiar, comidas típicas e artesanato local.

Outra pesquisa acerca do turismo Kalunga, realizada ao longo das festividades locais no ano de 2008 (SIRICO, 2008), levantou questões socioculturais relacionadas às visitações. Uma das perguntas do questionário aplicado, dizia respeito ao contato dos moradores com turistas, questionando quantos por cento dos moradores haviam tido contato com eles. $86 \%$ dos entrevistados afirmaram já terem tido algum tipo de contato com os visitantes, mas apenas $66 \%$ deles manifestaram interesse em trabalhar com atividades relacionadas. Percebe-se que o turismo permeou grande parte do território Kalunga, mas isso não significa que toda a comunidade esteja se beneficiando do ocorrido. Existe uma grande discrepância entre as diferentes localidades e o fluxo turístico relacionado. A maior parte dos atrativos visitados está no Engenho II, que devido a sua proximidade à sede do município recebe um fluxo constante de turistas. Lá, a contribuição econômica dessa atividade se faz evidente na renda das famílias, como será tratado mais adiante. 
Assim, apenas 56\% dos entrevistados por Sirico (2008) já haviam prestado algum serviço turístico, como receber visitantes em suas moradias, oferecer refeições ou como guias. Mas, apesar disso, 91\% dos participantes relataram acreditar que a inserção da atividade turística junto à comunidade Kalunga poderia ser uma alternativa para melhoria das condições de vida da população em geral. Entretanto, os membros da comunidade também estão cientes dos impactos negativos que o turismo pode trazer, por isso Costa reflete:

\begin{abstract}
Mas o turismo também pode ser um problema para nossa comunidade uma vez que ele traz dinheiro e desenvolvimento vem junto vários problemas: lixo, as drogas em geral, a prostituição e o principal de tudo que é a nossa cultura. A comunidade precisamos de apoio para melhor estar recebendo o turismo nas comunidades kalunga, hoje a comunidade que mais está preparada para receber o turista é o Engenho II, porque já tem toda uma organização de estabelecimentos prontos, (restaurantes, meio de comunicação, hospedagens, vários condutor de visitante capacitados entre outros) (COSTA, 2013).
\end{abstract}

Os poucos dados socioeconômicos produzidos especificamente sobre a comunidade Kalunga se limitam a dados esparsos sobre comunidades pontuais. São poucos os dados produzidos sobre todo o território. Algumas comunidades foram mais estudadas do que outras, permitindo um retrato mais preciso delas. Mas, é importante que não sejam feitas generalizações a partir dessas pequenas amostras, uma vez que as condições dentro do território variam muito de uma comunidade para outra, como já foi citado.

Os dados abaixo são referentes às comunidades de Cavalcante, e foram obtidos a partir dos agentes de saúde locais. Eles dizem respeito ao número de moradores e de famílias no ano de 2013. As localidades contabilizadas são: Vão de Almas, Vão do Moleque e Engenho II (Tabela 3). Além das informações sobre as famílias que permanecem dentro território, os dados mostram que cerca de dois mil remanescentes de quilombolas moram hoje na cidade de Cavalcante, totalizando 5.650 Kalungas só nesse município. Estima-se que o total, entre Cavalcante, Monte Alegre e Teresina, seja algo entre 9 e 11 mil pessoas (COSTA, 2013).

Tabela 3 - Número de famílias e pessoas por localidade Kalunga, no município de Cavalcante - GO, no ano de 2013 (fonte: COSTA, 2013)

\begin{tabular}{lcc}
\hline Comunidade & № de famílias & № de pessoas \\
\hline Vão de Almas & 215 & 1.075 \\
Vão do Moleque & 390 & 1.950 \\
Engenho II & 125 & 625 \\
Vivendo na cidade de Cavalcante & - & 2.000 \\
Total estimado & - & $\mathbf{5 . 6 5 0}$ \\
\hline
\end{tabular}


A principal atividade econômica (não monetária) da comunidade Kalunga, como um todo, ainda é a agricultura familiar, através das roças, que possuem fins de autoconsumo (AVELAR e DE PAULA, 2003; UNGARELLI, 2009; BAIOCCHI, 1999). Esse assunto é tema da presente pesquisa, e será tratado em detalhes ao longo dos próximos capítulos.

\subsection{CULTURA GERAL}

\subsubsection{Festas, Danças e Música}

A cultura Kalunga guarda em suas raízes uma profunda relação com ciclos de plantios e colheitas. Dessa forma, suas festividades são realizadas em períodos simbólicos do ciclo produtivo e são voltadas para santos que se acredita terem poderes sobre o clima e sobre a produtividade (BAIOCCHI, 1999; UNGARELLI, 2009). Os tipos de festa são três: As Folias, as Festas e Romarias, e as Bocas da Noite (Tabela 4).

As folias precedem as Festas e Romarias. Elas são compostas por "grupos de até quinze pessoas que percorrem as casas com a finalidade de arrecadar doações para os festejos, ao mesmo tempo anunciam a sua realização" (BAIOCCHI, 1999, p. 46). As mais famosas são a Folia de Reis, em janeiro, a Folia do Divino, de São João, de Santo Antônio e de São Sebastião em junho, de Nossa Senhora das Neves em agosto, de Nossa Senhora do Livramento em setembro, e de São Simão em outubro. Os foliões passam cantando de casa em casa pedindo a "esmola", que pode ser comida, bebida ou dinheiro. Em cada parada, as famílias das casas oferecem refeições fartas aos foliões, que comem e rezam juntos.

Ao final das folias existe o Arremate, uma tradição que consiste no fechamento das celebrações. Ele pode se dar junto ao Bendito de Mesa (ladainha ao redor da mesa que agradece pela comida farta) (Figura 11), ou quando o dia vem raiando, na casa de um morador, que oferece o café da manhã para os foliões. Essa atividade é sempre acompanhada de fogos de artifício, que anunciam o final do evento.

As Festas são os eventos propriamente ditos, com locais fixos de acordo com o calendário dos Santos. As principais são: A Festa de Reis, que acontece na Contenda, no Vão de Almas e no Vão do Moleque, em Janeiro; A Festa de Santo Antônio e de São João, que acontecem em Junho na Contenda, no Vão de Almas, no Vão do Moleque e no Riachão; A Festa de Nossa Senhora da Abadia e o Império, que acontecem no mês de agosto no Vão de Almas; o Império de São Gonçalo do Amarante e a Festa de Nossa Senhora do Livramento, que acontecem em setembro no Vão do Moleque; e a Festa de São Simão, que acontece em outubro no Kalunga. Quando acontece de um padre visitar as comunidades nas datas festivas, realizam-se os batizados e casamentos coletivos, seguidos 
de muito forró e comida. Nessas ocasiões também ocorre o levantamento do mastro, as danças típicas (masculinas e femininas) e as banquetes.
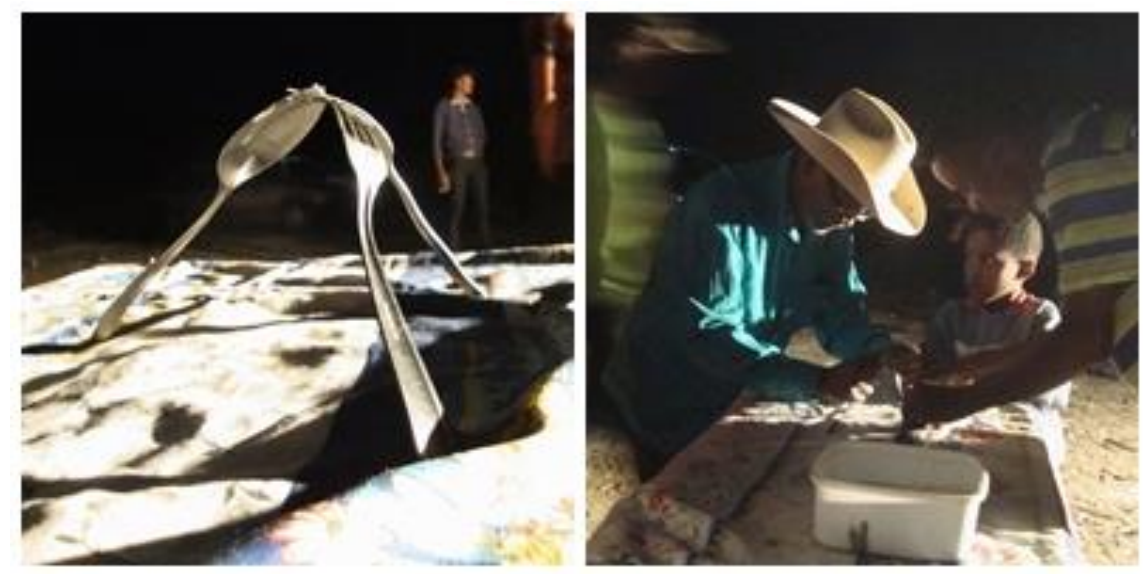

Figura 11 - Bendito de Mesa durante a Festa de Santo Antônio do Engenho II, 2014, onde o folião arruma dois garfos e uma colher sobre a mesa onde será realizada a cantoria de agradecimento (Fonte: Ivany Neiva)

A Boca da Noite é um culto santo que ocorre dentro do espaço domiciliar em escala familiar. Geralmente se dá na casa do casal mais velho descendente do ancestral do grupo, onde a família se reúne para louvar seus santos. Ele ocorre uma vez por ano, e não possui uma data fixa, ao contrário das Festas. A preparação para essa atividade começa com no mínimo quinze dias de antecedência e todos os moradores da casa tomam parte, inclusive as crianças (BAIOCCHI, 1999). A respeito das festas e sua importância na socialização da população Kalunga, Jatobá argumenta:

Interessante observar qual nível de solidariedade e identificação está sendo reforçado em cada festa. A área de abrangência aponta nessa direção. A "boca da noite" reforça a unidade da localidade, as folias unem os parentes, e as romarias reforçam a unidade da comunidade, pois a abrangência é a articulação das regiões (JATOBA, 2002).

Vários trabalhos foram escritos unicamente sobre as datas religiosas da comunidade Kalunga, alguns detalhando minuciosamente as idiossincrasias de cada festividade. Essas pesquisas ajudam a compreender o valor simbólico dessas datas para a comunidade, não só como espaço sagrado de louvação, mas como ambiente de integração entre diferentes núcleos familiares. É um espaço para demonstrações de fé e propagação de tradições, mas também é um espaço de reencontro entre famílias, de busca de parceiros e de entretenimento, como mostram Baiocchi (1999), Siqueira (2006), Jatobá (2002), Marinho 2008), Magalhães (2013), Lima (2012) e Rosa (2013) 
Tabela 4 - Calendário das Folias, Festas e atividades agrícolas da comunidade Kalunga (baseado em BAIOCCHI, 1999)

\begin{tabular}{|c|c|c|}
\hline Mês & Santo & Local \\
\hline Janeiro & Reis & $\begin{array}{l}\text { Riachão, Vão de Almas, Vão do Moleque e } \\
\text { Contenda }\end{array}$ \\
\hline Fevereiro & \multicolumn{2}{|c|}{ Limpeza e cuidados com as roças } \\
\hline Março & \multicolumn{2}{|c|}{ Limpeza e cuidados com as roças } \\
\hline Abril & \multicolumn{2}{|r|}{ Colheita } \\
\hline Maio & \multicolumn{2}{|r|}{ Colheita } \\
\hline Junho e Julho & $\begin{array}{l}\text { Divino } \\
\text { São João } \\
\text { Santo Antônio } \\
\text { São Sebastião }\end{array}$ & $\begin{array}{l}\text { Vão de Almas e Vão do Moleque } \\
\text { Sucurí, Vão de Almas e Vão do Moleque } \\
\text { Moleque, Contenda, Vão de Almas e Riachão } \\
\text { Riachão, Vão do Moleque e Vão de Almas }\end{array}$ \\
\hline Agosto & $\begin{array}{c}\text { Senhora das Neves } \\
\text { Nossa Senhora D’Abadia } \\
\text { Império }\end{array}$ & Vão de Almas \\
\hline Setembro & $\begin{array}{l}\text { Senhora do Livramento } \\
\text { Império de São Gonçalo } \\
\text { São Sebastião }\end{array}$ & Vão do Moleque \\
\hline Outubro & São Simão & Areias, Tinquizal e Kalunga \\
\hline Novembro & & Plantio \\
\hline Dezembro & & Plantio \\
\hline
\end{tabular}

Os Kalungas são guardiões de duas danças muito singulares, típicas do território quilombola do nordeste goiano. A primeira delas é a Curraleira, dançada unicamente pelos homens da comunidade, principalmente ao longo das folias, mas também durante as festas. O segundo estilo é a dança da Sussa (Figura 12), executada unicamente pelas mulheres, que rodam em tom de desafio umas com as outras, e que, em algumas ocasiões, equilibram garrafas de bebidas em cima da cabeça, demonstrando habilidade e concentração, onde os pés mal tocam o chão. A Sussa também é considerada uma dança de pagar promessa e deve ser tocada e dançada na hora certa, como no momento da subida do Mastro de Santo (BAIOCCHI, 1999). 

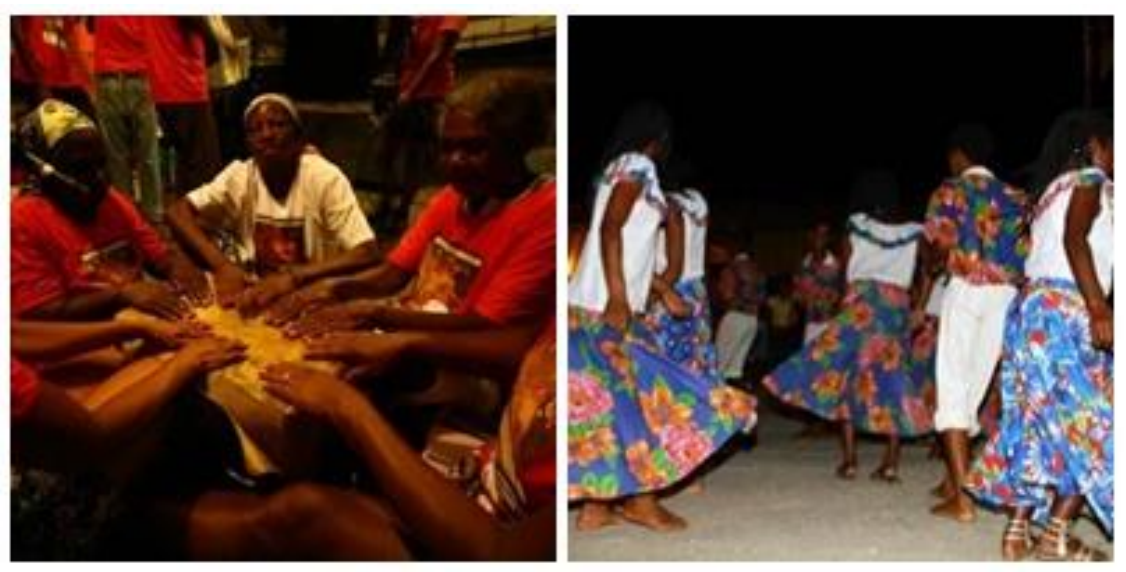

Figura 12 - Mulheres Kalungas batucando na "bruaca" (esquerda), e um grupo de dançarinas de Sussa (direita). Fotos de lon David. (Fonte: Marinho 2013)

Ambas as danças possuem um tom forte guiado por um batuque frenético, muitas vezes tocado nas "bruacas" (Figura 12) que são, literalmente, caixas de carregar mantimentos, feitas de pele de boi esticada sobre estruturas de madeira. Outro instrumento típico da região é o "onça", um tambor cilíndrico e comprido, com uma vara interna conectada a pele. Ele é tocado simultaneamente por duas pessoas, onde uma batuca na superfície da pele enquanto a outra passa um pano úmido e puxa a vara interna, como na cuíca. Essas e outras demonstrações artísticas marcam as dinâmicas das festas e alegram os participantes e observadores, como comenta Costa:

[...] o ato de beijar a bandeira, os "giros" da folia onde um grupo de foliões leva a bandeira em todas as casas da comunidade. As orações e a dança da curraleiras, sussa, o batuco e canto das rodas, são exemplos dos rituais que fazem parte das crenças e alegria das pessoas das nossa comunidade Kalunga (COSTA, 2013, p. 59).

\subsubsection{Moradias}

Fugindo das cidades coloniais e do seu sistema repressor, as populações negras que se refugiavam nos sertões brasileiros contavam apenas com aquilo que podiam retirar da natureza a fim de construir suas moradas. No princípio, o receio de serem capturadas novamente impunha às famílias quilombolas um estado de constante migração. Nesse período, as moradias tradicionais eram ranchos de parede e teto de palha, que podiam ser facilmente construídos e abandonados, dependendo de uma menor quantidade de recursos e de mão de obra. Conforme essas populações iam se estabelecendo e sentindo-se seguras para permanecerem em um mesmo lugar, os benefícios de se construírem casas mais elaborada aumentavam. Assim, começaram as casas com parede de madeira e parede de pau a pique, mas o telhado permaneceu sendo feito de palha. As amarrações dos tramados das casas eram feitas com embira, tipo de corda retirada da própria madeira. 
Segundo Jonatas Nunes Barreto (2006), as moradias Kalungas podem ser divididas em duas categorias distintas: as de tipologia tradicional e as de tipologia híbrida. As casas tradicionais são aquelas construídas empregando-se pessoas da comunidade com técnicas tradicionais assimiladas pela tradição oral e desenvolvidas ao longo dos séculos com materiais disponíveis na própria localidade. Já as moradias de tipologia híbrida são aquelas que empregam tecnologias mistas, que mesclam tecnologias tradicionais e modernas, com o emprego de materiais pré-fabricados comuns. As construções tradicionais ainda podem ser divididas em dois tipos diferentes: a)as casas com parede de taipa, madeira ou fibra vegetal, e b)as casas com parede de adobe.

As moradias geralmente apresentam um pé direito baixo, com poucas entradas de luz. Comumente cada casa abriga apenas um grupo familiar (Tabela 5), mas são famílias grandes, e a média de cômodos por casa é de e 2 a 6 . Em quase $40 \%$ dos domicílios avaliados, apenas um dos cômodos tinha como destinação dormitório (Tabela 6). As cozinhas geralmente são externas à casa, e algumas vezes possuem até módulo externo exclusivamente para elas, já que a fuligem do fogão á lenha causa transtorno para os moradores. As casas tradicionalmente não têm banheiros, uma vez que não existia sistema de esgoto ou fossa. Atualmente, alguns lares em comunidade com maior infraestrutura possuem sistema de fossa séptica.

Tabela 5 - Distribuição percentual dos domicílios, segundo o número de famílias, por município. Comunidade quilombola Kalunga. (Fonte SEPPIR-FUBRA, 2004)

\begin{tabular}{ccccc}
\hline $\begin{array}{c}\text { Número de } \\
\text { Famílias }\end{array}$ & Cavalcante & Teresina & Monte Alegre & Total \\
\hline $\mathbf{1}$ & $93,6 \%$ & $87,2 \%$ & $92,8 \%$ & $92,4 \%$ \\
$\mathbf{2}$ & $5,8 \%$ & $11,3 \%$ & $7,0 \%$ & $7,0 \%$ \\
$\mathbf{3}$ & $0,5 \%$ & $0,7 \%$ & - & $0,4 \%$ \\
$\mathbf{5}$ & - & $0,7 \%$ & - & $0,1 \%$ \\
\hline
\end{tabular}

A palha preferida para a construção dos telhados é a pindoba ou o buriti, que apesar de terem uma folha menor que a de outros cocos, é mais resistente para esse tipo de trabalho, durando em média de oito a dez anos. Entretanto, algumas comunidades não possuem abundância dessas palmeiras, como no caso do Vão de Almas, o que faz com que as famílias dessas localidades precisem trocar os telhados anualmente, ou fretarem carros para trazerem a palha de pindoba de outras partes do território. 
Tabela 6 - Porcentagem de cômodos nas casas e a porcentagem destinada exclusivamente para dormitório das famílias. Quilombo Kalunga. Dados da SEPPIR-Fubra 2004

\begin{tabular}{ccc}
\hline $\begin{array}{c}\text { Número de } \\
\text { Cômodos }\end{array}$ & Total na casa & $\begin{array}{c}\text { Utilizados } \\
\text { somente como } \\
\text { dormitórios }\end{array}$ \\
\hline $\mathbf{0}$ & $0,1 \%$ & $0,1 \%$ \\
$\mathbf{1}$ & $4,3 \%$ & $38,7 \%$ \\
$\mathbf{2}$ & $17,3 \%$ & $28,8 \%$ \\
$\mathbf{3}$ & $17,4 \%$ & $20,3 \%$ \\
$\mathbf{4}$ & $18,5 \%$ & $10,6 \%$ \\
$\mathbf{5}$ & $18,2 \%$ & $0,9 \%$ \\
$\mathbf{6}$ & $15,6 \%$ & $0,3 \%$ \\
$\mathbf{7}$ & $4,6 \%$ & - \\
$\mathbf{8}$ & $2,9 \%$ & - \\
$\mathbf{9}$ & $0,3 \%$ & - \\
$\mathbf{1 0}$ & $0,2 \%$ & - \\
\hline
\end{tabular}

Atualmente, algumas comunidades já possuem casas de alvenaria, principalmente aquelas onde políticas públicas habitacionais já chegaram, mas as construções com tijolos de adobe são ainda preferidas. Elas oferecem maior conforto térmico aos moradores e aproveitam o material local, o que é indispensável quando se trata de localidades de difícil acesso, onde o preço do frete de caminhões é abusivo. Outro fator, que também influencia os tipos de construções atuais, é a preocupação com a saúde, como explica Costa:

[...] Hoje na comunidade a realidade é bem melhor, mais da metade das famílias já tem uma casa em melhores condições para se morar, algumas famílias tem casa de telha mesmo tendo que carregar as vez no lombo do muar (burro), uma distância longe mais vale a pena ter todo esse esforço porque tem mais conforto e é menos sujeito aos insetos, como o barbeiro que um transmissor da doença de chagas. Mas ainda tem muitas pessoas que vive em má condições quando se falamos em moradias, porque tem muitas famílias de ate 10 pessoas que vive em uma casa de no máximo 2 cômodo e fechada de pau a pique (COSTA, 2013, p. 56).

Ainda hoje nos locais das festas fixas e nas áreas de roça, os ranchos de palha, as casas de pau-a-pique, adobe e de madeira estão presentes como uma demonstração viva das tecnologias da cultura quilombola e sertaneja. 

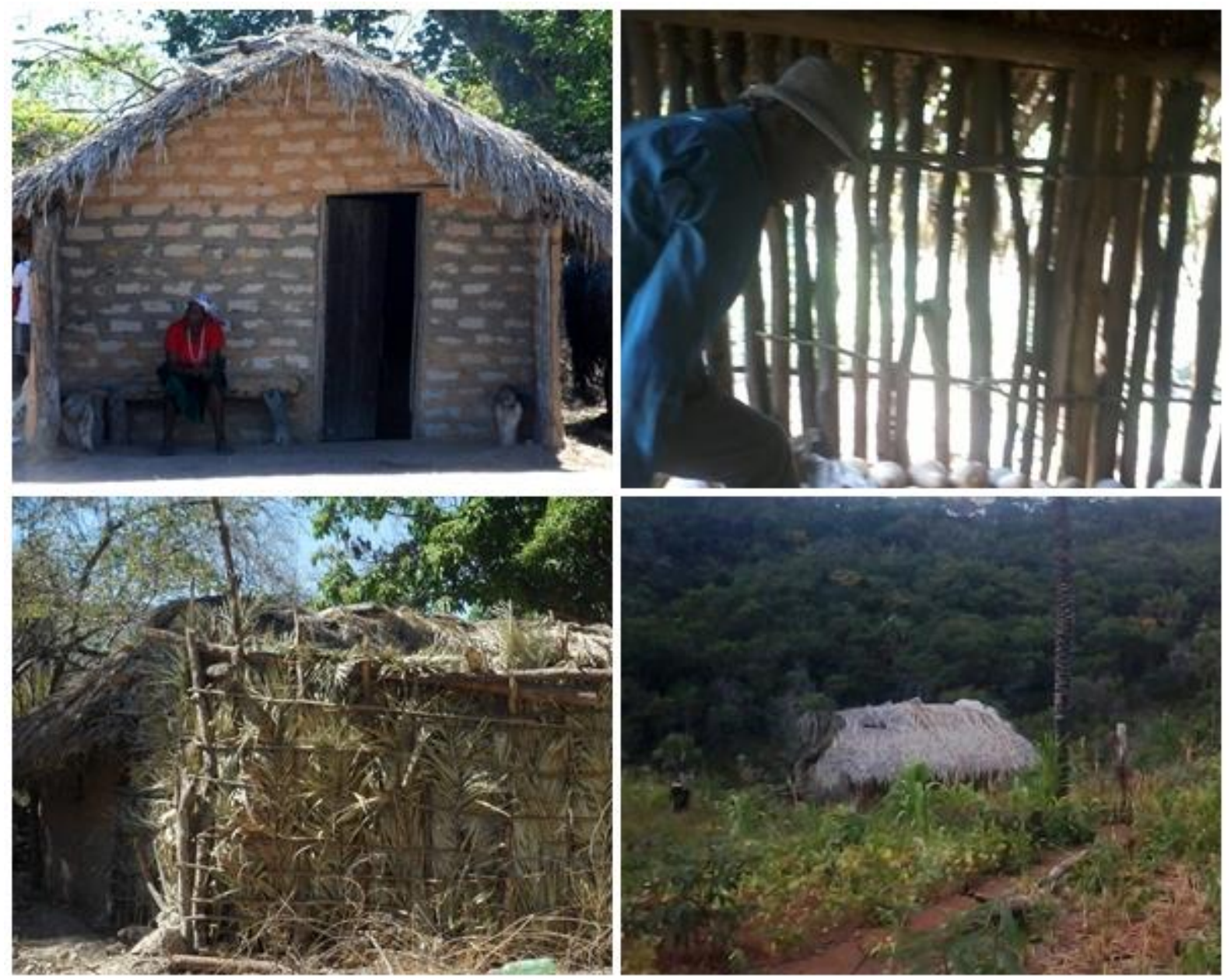

Figura 13 - Exemplos de casas Kalungas. No sentido horário, começando da parte superior esquerda: Casa de adobe da comunidade Capela, no Vão de Almas; Racho com parede de madeira, Engenho II; Vão de Almas; Rancho de taipa, Engenho II ; Palhoça com parede de palha. (Fotos: Cecilia Ricardo e Ludivine Eloy, 2014)

\subsection{ESTRUTURA POLÍTICA}

Após o estreitamento das relações entre os quilombolas e os "de fora", diversos conflitos territoriais e culturais, que já existiam de forma latente, se intensificaram, anunciando uma necessidade de organização politica por parte dos Kalungas, com o intuito de se defenderem e reivindicarem seus direitos. O primeiro passo nessa direção se deu no ano de 1999, com a criação da Associação Quilombo Kalunga (AQK). Essa organização comunitária, também conhecida como Associação Mãe, surgiu com a missão de defender e representar os quilombolas dos municípios de Cavalcante, Monte Alegre e Teresina, proporcionando unidade legal e administrativa à população do Sítio Histórico.

Paralelamente à AQK, existem outras três associações menores, responsáveis por representar as comunidades quilombolas de cada um dos municípios. São elas: a Associação Kalunga Cavalcante (AKC), a Associação Kalunga de Teresina de Goiás (AKT), 
e a Associação Kalunga de Monte Alegre (AKMA). Elas são organizações não governamentais sem fins lucrativos (ONGs), que possuem o objetivo de representar as comunidades junto à associação Mãe (AQK) e ir "trabalhado junto à melhoria continua das formas de ganho através do uso sustentável dos recursos naturais e culturais" (COSTA, 2013).

A localidade Engenho II também possui uma associação exclusiva para os seus moradores, chamada Associação Comunitária Kalunga Engenho II, criada no ano de 2009, que objetiva cuidar das questões especificas da comunidade, resolvendo conflitos internos e informando os moradores dos assuntos que envolvam o território e suas famílias.

Recentemente, em 2012, um grupo de alunos do curso de Licenciatura em Educação do Campo (LedoC) da Universidade de Brasília (UnB), apoiados por professores e pesquisadores, decidiram criar a Associação de Educação do Campo do Território Kalunga e Comunidades Rurais (EPOTECAMPO). O objetivo foi fortalecer a educação no campo a fim de diminuir o êxodo rural, além de lutar por novas políticas públicas voltadas para a educação. Nas palavras de um dos seus fundadores, a EPOTECAMPO está em:

[...] busca de conscientizar e apoiar fortalecer as necessidades de acompanhamento das atividades dentro do sitio histórico, em relevância a Educação, Cultura, Ambiente. $\mathrm{Na}$ comunidade kalunga, as reuniões acontece em alternância nos três município que abrange, Teresina Cavalcante e Monte Alegre de Goiás (COSTA, 2013, p. 47).

O que esta associação pretende: queremos buscar a colaboração e apoio de todos. "A sua colaboração! Apoie há esta luta!". Porque juntos podemos diminuídos o êxodo rural, para que nossos filhos não sejam obrigados a crescerem longe de nós, em busca de educação e sobrevivência, pois é possível permanecer em nosso habitat, desde que nos seja oferecido oportunidade para viver com dignidade no campo, no lugar onde nascemos, tanto quanto existe na cidade (COSTA, 2013, p. 48).

Com isso, se espera ter criado um panorama da atual conjuntura dos Kalunga, que passam por um processo acelerado de transformações e ressignificações, mas que permanecem unidos em busca de seus direitos territoriais e sociais. Um importante passo nessa direção se dá com a formação de jovens pesquisadores Kalungas, que têm a oportunidade de realizar essa troca entre meio acadêmico e meio rural de forma autêntica. Os trabalhos gerados por esses pesquisadores produzem um conhecimento da comunidade para a comunidade, e que por isso possui grande permeabilidade dentro da mesma, diminuindo os problemas oriundos da falta de feedback, tão comum nas pesquisas acadêmicas atuais. 


\section{CAPITULO 2 - ESCOLHAS PARA PERCORRER A TRILHA}

As etnometodologias, que ganharam força na metade do século $X X$, surgiram com o intuito de investigar o "outro" dentro de uma nova abordagem. Segundo Paul E. Little, elas propõem a "suspenção de valores e (pre)conceitos do pesquisador para poder chegar a uma compreensão profunda das lógicas e estruturas internas de uma sociedade determinada" (2010, p. 18). É comum que as sociedades escolhidas para tais pesquisas sejam grupos não ordinários, que se diferenciam da sociedade ocidental urbana atual. Dentro desses grupos, surge uma categoria chamada de comunidades ou populações tradicionais. Esse conceito chegou ao Brasil na década de 1990, e carregava duas bandeiras ideológicas distintas: a do movimento ambientalista e a dos direitos étnicos. O termo leva em si um conjunto de valores culturais coletivos, que, nacionalmente, fazem alusão à:

[...]grupos sociais que, conquanto culturalmente distintos no tecido da sociedade nacional e caracterizados por formas cultural e historicamente específicas de apossamento da terra e de apropriação dos recursos naturais, estão desprovidos de tratamento legal diferenciado que reconheça o seu direito às terras que tradicionalmente habitam, tais como índios e grupos remanescentes de quilombos (BARRETTO FILHO, 2006).

Os saberes locais e conhecimentos associados a essas populações se tornam, muitas vezes, o foco das etnopesquisas, como ocorre na etnobotânica, na etnobiologia e na etnoecologia. Esta última, utilizada como base metodológica da presente pesquisa, pode ser definida, segundo Little (2010), como o estudo etnográfico e comparativo dos sistemas específicos que um grupo humano utiliza na interação com seu meio biofísico e social. Esses sistemas são baseados em "conhecimentos tradicionais", que são definidos amplamente como:

Todos os conhecimentos pertencentes aos povos indígenas, às populações agroextrativistas, aos quilombolas, aos ribeirinhos e aos outros grupos sociais que se dizem tradicionais, que sejam utilizados para suas atividades de produção e reprodução nas suas respectivas sociedades (LITTLE, 2010, p. 11).

A pesquisa desenvolvida nesse trabalho se utiliza dos preceitos da "intercientifficidade" para nortear as interações entre o sistema de conhecimento tradicional dos Kalungas e o sistema da ciência moderna, compreendendo que esse relacionamento entre culturas cria inter-relações entre os diferentes sistemas de conhecimento que devem ser consideradas e observadas ao longo da etnopesquisa.

Para subsidiar as metodologias adotadas, parte-se da definição que Clinfford Geertz (2012) dá para cultura. Ele, baseando-se nos preceitos de Max Weber de que o homem é um animal amarrado a teias de significado que ele mesmo teceu, diz que cultura seria 
"essas teias e a sua análise; portanto, não como uma ciência experimental em busca de leis, mas como uma ciência interpretativa, à procura do significado" (GEERTZ, 2012, p. 4). E é na busca das teias Kalungas de produção e alimentação que o presente trabalho se insere.

\subsection{METODOLOGIA}

A primeira etapa da pesquisa foi pautada na pesquisa bibliográfica e na revisão da literatura. Elas se iniciaram a partir de buscas nas plataformas virtuais da Biblioteca da Universidade de Brasília (UnB), da Universidade Federal de Goiás (UFG) e no portal de periódicos da CAPES. A essa busca se sucederam visitas à Biblioteca da Fundação Cultural Palmares e à Biblioteca do Centro de Desenvolvimento Sustentável da UnB. Nessas buscas, além do termo Kalunga, também se inseriram temas mais, ou menos, familiares à pesquisadora, como segurança alimentar, soberania alimentar, métodos de investigação do consumo alimentar, quilombolas, comunidades tradicionais, chapada dos veadeiros, comunidades rurais negras, politicas agroambientais, sistemas agrícolas tradicionais, transferência condicionada de renda e politicas públicas compensatórias, entre outras.

As principais pesquisadoras utilizadas como referencial teórico no tocante da cultura Kalunga foram: a pioneira Mari Baiocchi (1996; 1999), Danielli Jatobá (2002), Alessandra Velloso (2007) e Daniella Ungarelli (2009). Entretanto, outras obras sobre essa comunidade foram de grande valia, como os estudos jurídicos de Franco (2012) e Siqueira (2012), a profunda abordagem de gênero da pesquisadora Tereza Godinho (2008), os estudos sociais de Thaís Marinho (2008), os levantamentos nutricionais de Mariana Cordeiro (2013), a visão espacial do Jonatas Barreto (2006) e a abordagem orgânica dos pesquisadores Kalungas Vimar Costa (2013) e Wanderleia Rosa (2013), entre outros não citados.

Optou-se, para dar continuidade à pesquisa, por um enfoque qualitativo. Dentro das metodologias oferecidas por essa perspectiva, as mais adotadas pelas etnopesquisas são a etnografia e a pesquisa-ação. Pensando que a primeira ensina como ir ao campo, e a segunda como lidar com as demandas que surgem a partir do campo (NAVES, 2006), a utilização conjunta das duas possibilita um trabalho mais completo e estruturado. Em vista disso, a presente pesquisa, que busca uma abordagem qualitativa da comunidade Kalunga, se baseia nos instrumentos desses dois métodos a fim de responder as perguntas fundamentais da presente dissertação.

Partindo das perguntas primordiais, de caráter mais genérico, que foram despertadas ao longo do período de revisão de literatura e das visitas exploratórias realizadas em dezembro de 2013, iniciou-se o primeiro ciclo de pesquisa, onde essas perguntas levaram a 
uma coleta de dados iniciais, que foram registrados e posteriormente analisados, levando a um novo nível de perguntas, essas mais específicas, sobre o campo analisado. As perguntas primordiais se baseavam em questionamentos a cerca dos sistemas alimentares da comunidade Kalunga, incluindo os seus processos produtivos e os significados agregados às atividades relacionadas. As questões levantadas foram diversas vezes modificadas e reavaliadas, conforme as visitas ao campo despertavam novas perguntas. Assim, ao longo de dez meses de pesquisa de campo, buscou-se transformar o exótico em familiar respondendo a um conjunto de perguntas que formavam os cinco objetivos específicos da pesquisa:

a. Como são os sistemas alimentares da comunidade (atuais e passados), incluindo espécies, procedimentos, preparos e dinâmicas culturais envolvidas?

b. Quais são as alterações e continuidades nos sistemas alimentares locais, a partir da comparação das características atuais e passadas?

c. Quais são as possíveis disposições e motivações relacionadas com as mudanças e permanências nos sistemas alimentares?

d. Qual é o nível atual de segurança alimentar da comunidade?

e. Quais são os fatores que dificultam a garantia da segurança alimentar da comunidade e a preservação da agrobiodiversidade local?

Em busca dessas respostas, ainda na fase etnográfica, a primeira ferramenta de pesquisa utilizada foi a observação participante, que segundo Spradley (1980), possui o objetivo de engajar o pesquisador nas atividades estudadas e possibilitar a observação das mesmas. Nessa etapa, a pesquisadora realizou diversas visitas à comunidade, onde participou de festividades e atividades cotidianas. Esses momentos de descobertas e entrosamento se prolongaram por todos os onze meses de pesquisa, e cada nova família apresentada, cada nova localidade, significava um novo ciclo de pesquisa, com novos dados, novas análises e novas perguntas.

Dentre as atividades realizadas dentro das observações participantes, pode-se citar a produção de farinha de mandioca, a recepção dos turistas no CAT, a preparação das "comidas de festa", as romarias e ladainhas religiosas, as palestras, reuniões e capacitações comunitárias, a coleta de frutos do cerrado, a produção de óleos, a colheita do feijão e do arroz, a venda da produção em feiras, entre outras. Essas atividades auxiliaram não só a pesquisadora a conhecer melhor a comunidade, mas principalmente a comunidade a conhecer melhor a pesquisadora. A confiança é um elemento fundamental para uma pesquisa que pretende conhecer a vida da comunidade Kalunga, já extremamente desgastada com projetos e pesquisas de todos os tipos. A falta de confiança de que a 
pesquisa sirva a algum propósito positivo para a comunidade leva, muitas vezes, a uma falta de colaboração generalizada, baseada em uma desconfiança e autopreservação típica de um grupo que foi obrigado a se refugiar durante quase três séculos.

As entrevistas semiestruturadas e abertas também foram utilizadas como instrumentos de coleta de dados e informações relevantes. Esse modelo de arguição garante um conjunto básico de informações sem limitar possíveis contribuições inesperadas, que comumente surgem em um diálogo não formal (UNGARELLI, 2009). As famílias foram escolhidas de acordo com a localização, experiência com o trabalho na roça, experiência na produção de produtos alimentares, terem nascido e vivido no território e disponibilidade de tempo para participarem da pesquisa. Como não foi possível a realização de uma palestra introdutória coletiva nas comunidades, os entrevistados foram, na maioria dos casos, indicados por outros pesquisadores e por membros da própria comunidade.

A falta de uma reunião comunitária em cada localidade, como havia sido proposto no plano de trabalho, se deveu ao, já citado, fato de a comunidade possuir um desgaste justificado em relação às visitas constantes de pesquisadores acadêmicos. As frequentes pesquisas estabelecidas no território Kalunga, são fracamente explicadas à população, que, não compreendendo o sentido das atividades, ou não corroborando da validade delas, acaba exaurida em relação a esse tipo de interação.

As entrevistas foram realizadas com seis famílias da comunidade Engenho II e com cinco famílias da região do Vão de Almas. Todas elas foram individualmente informadas a respeito dos objetivos e finalidades da pesquisa, sendo arguidas verbalmente a respeito do interesse em participar da pesquisa. As entrevistas, gravações e registros fotográficos foram, sempre, autorizados previamente. Os membros da família escolhidos foram o casal provedor principal (mais velho) dentro de cada moradia. A princípio, pensou-se em entrevistar prioritariamente as mulheres de cada núcleo familiar, mas as atividades produtivas e alimentares da comunidade Kalunga possuem, predominantemente, um caráter misto, envolvendo homens e mulheres em diferentes medidas.

Nenhuma das entrevistas foi realizada sem um período prévio de convívio com as famílias. Elas ocorreram, em média, depois de dois ou três encontros entre a pesquisadora e o núcleo familiar. O diálogo informal que se estabeleceu nessas visitas foi de fundamental importância para o elo de confiança entre pesquisadora e família, que permitiu aos entrevistados se sentirem mais a vontade ao longo dos relatos. Isso possibilitou uma maior liberdade nos diálogos, fornecendo informações relevantes sobre os hábitos de vida e dinâmicas sociais dos Kalungas. 
Em decorrência do sistema político local e de sua herança coronelista e personalista, uma das famílias entrevistadas pediu que seus nomes fossem mantidos em anonimato na pesquisa, por isso, visando não destaca-los dos demais, todos os nomes dos informantes foram omitidos, e substituídos por identificações apenas de gênero e localidade, uma vez que, apenas a abreviação dos nomes, em pequenas comunidades, não permite o real sigilo de identidade.

Além das observações participantes e das entrevistas, a pesquisa ainda contou com notas feitas nos diários de campo, diálogos informais, vinte e nove visitas às roças, onze visitas às casas, quintais e hortas, dez trilhas guiadas pelo cerrado, fotografias de pessoas, locais e atividade pertinentes, quinze mapeamentos sobre imagens de satélite e pequenas filmagens de processos específicos. Os mapeamentos, realizados sobre imagens de satélite da região do Sítio Histórico, foram trabalhados em alguns casos individualmente, mas na maioria das vezes, de forma coletiva, com mais de dois membros da família, incluindo as crianças, com enorme capacidade de abstração sobre as fotos. Essa atividade foi bem recebida, e representava uma forma de entretenimento para os participantes.

A experimentação dos produtos alimentares Kalungas, também foi uma ferramenta importante que possibilitou a ampliação do entendimento sobre o paladar identitário da comunidade, assim como foi sugerido por Ungarelli em seu trabalho de campo (2009). Essa experiência, que na maioria das vezes ocorreu dentro do espaço das cozinhas domiciliares, permitiu a observação dos hábitos ao longo das refeições e das dinâmicas familiares envolvidas.

O diário de campo, companheiro incansável de toda hora, foi um instrumento valioso ao longo da etapa de coleta e análise de dados. Ele permitiu a criação de um processo reflexivo constante que estimulou a avaliação das atividades já executadas. Ademais, a vivência de campo se revelou uma experiência extremamente educativa e valiosa, ampliando os horizontes acadêmicos e não acadêmicos da pesquisadora, que foi muito bem recebida em todas as comunidades e lares.

A pesquisa-ação foi utilizada ao longo do trabalho como ferramenta de reavaliação dos objetivos e no auxilio da construção das novas perguntas que foram surgindo ao longo dos meses. Pois a:

[...] pesquisa-ação, além de engajar o pesquisador na situação estudada, transformando-o em um observador participante, coloca a importante questão da ação planejada no campo em estudo. É necessário ressaltar que a ação é gerada no próprio processo de investigação (NAVES, 2006, p. $11)$. 
Nessa metodologia, ainda de acordo com Naves, os participantes deixam de ser vistos como meros informantes e são vistos como produtores ativos de conhecimento, como de fato o são. Dessa forma, muitas das respostas e soluções apresentadas aos questionamentos da pesquisa surgiram dos próprios entrevistados, que ao longo da pesquisa foram essenciais, não só como fonte de dados, mas principalmente como agentes questionadores da própria realidade.

A fase da análise de dados não foi realizada somente após a etapa de campo, como geralmente é recomendado numa análise de conteúdos. Ela ocorreu ao longo dos últimos seis meses de pesquisa, paralelamente à coleta de dados (que se estendeu até o último mês da pesquisa). Isso se deveu ao fato de que, com o intuito de não perturbar as atividades cotidianas das famílias, a pesquisadora permitiu que as mesmas escolhessem as datas das visitas, o que implicou em diversas remarcações e atrasos, causando uma delonga maior do que o esperado para a finalização da coleta de dados. Contudo, esses ocorridos só vieram enriquecer ainda mais a pesquisa, permitindo que nesse meio tempo várias outras informações valiosas fossem recolhidas.

Para mensurar quantitativamente o nível de segurança alimentar da população, escolheu-se utilizar a Escala Brasileira de Insegurança Alimentar (EBIA), que consiste na aplicação de um questionário com quinze perguntas que devem ser respondidas com sim ou não, a partir da situação alimentar da família nos últimos três meses. Após essa etapa, de acordo com o número de questões respondidas positivamente, indica-se em qual categoria a família se encontra. São elas a Segurança Alimentar (SA), a Insegurança Alimentar Leve (IAL), a Insegurança Alimentar Moderada (IAM) e a Insegurança Alimentar Grave (IAG).

Ainda a respeito da segurança alimentar, foi feita uma análise qualitativa sobre as perguntas do EBIA, a fim de se compreender a conjuntura que levava às respostas assinaladas mais frequentes. Essa etapa se deu por meio das entrevistas semi-estruturadas e estruturadas, já citadas anteriormente.

\subsection{ESTUDO DE CASO}

O Sítio Histórico e Cultural Kalunga é um território grande, que, com os seus 237 mil hectares, possui quatro vezes a área do Parque Nacional da Chapada dos Veadeiros. Essa enorme extensão, já em 2004, abrigava 62 povoados, onde mais da metade não passam de agrupamentos de no máximo dez casas (Tabela 7). Hoje em dia, o número de famílias por comunidade já cresceu bastante, mas os dados atualizados só existem para alguns agrupamentos, como os citados na Tabela 3. As localidades eram comumente distribuídas 
em cinco grandes regiões, que Baiocchi (1999) chamaou de municípios: o Kalunga, o Vão das Almas, O Vão do Moleque, O Ribeirão dos Bois e Contenda. Entretanto, essa divisão, atualmente, está se modificando para uma mais resumida, com apenas três grandes regiões: o Vão de Almas, o Vão do Moleque e o Vão da Contenda (Figura 14), como já aparece no trabalho de Magalhães (2013).

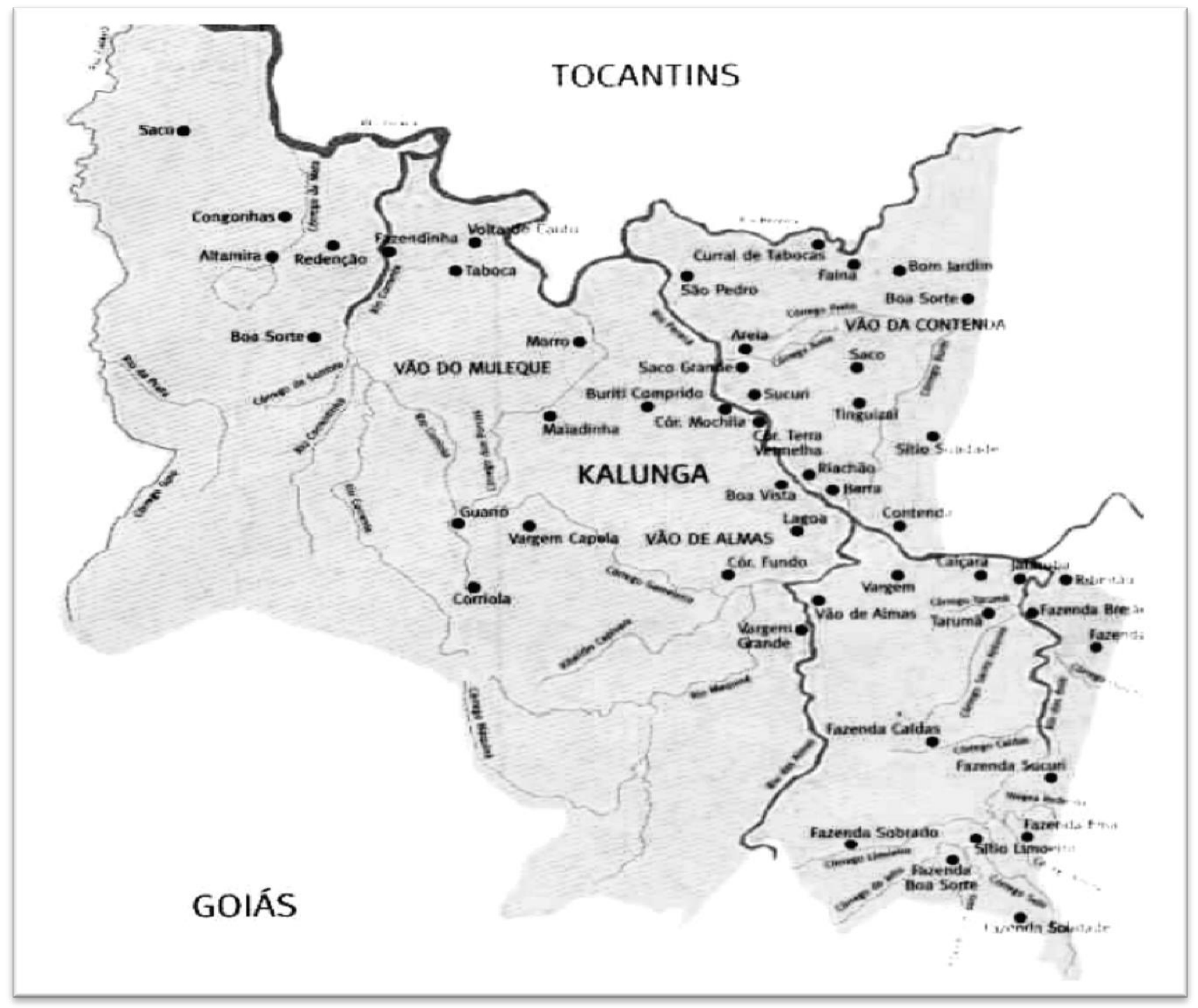

Figura 14 - Regiões do Território Kalunga, por município (Fonte: Secretaria de Educação Fundamental BRASIL, 2001).

Os povoados do quilombo Kalunga apresentam diferentes estados de desenvolvimento de suas infraestruturas, o que acarreta diferenciados padrões de consumo e hábitos produtivos. Partindo desse pressuposto, verificado em campo, o presente trabalho buscou dois núcleos que representassem essa diversidade, de forma a criar um retrato mais amplo e comparativo dos sistemas alimentares Kalungas. Desse modo, foram eleitos dois 
povoados que retratassem diferentes realidades da comunidade: o Engenho II e o de Vão de Almas. Apesar da segunda localidade não ser um único povoado propriamente dito, ela representa um estilo de distribuição geográfica típico desse quilombo, mas que hoje está lentamente sendo substituído pelas pequenas aglomerações familiares, similares a vilarejos.

A ocupação territorial no Vão de Almas (e na maior parte do território) segue um formato, adotado durante os anos de fuga da escravidão, que dificulta a localização das casas para aqueles que passam nas estradas. Essa estratégia estava ligada à sobrevivência das comunidades, que dependiam do isolamento e invisibilidade para resistirem às investidas de recaptura por parte dos senhores de terras. Esse modelo de distribuição espacial chamou a atenção de outros pesquisadores (BAIOCCHI, 1999; BARRETO, 2006; JATOBÁ, 2002), como demonstra Jatobá em sua dissertação:

Observei, com surpresa, que não enxergava as casas da estrada que vai de Monte Alegre ao Riachão, e que também não as enxerguei quando naveguei o Rio Paranã, que corta a comunidade. Não há qualquer aldeamento ou vila em toda a extensão da área ocupada pela comunidade. As residências mantêm-se com um significativo afastamento e ficam invisíveis em meio ao cerrado. Revela-se pra mim, então, o segundo traço da estratégia social historicamente adotado por essa comunidade: a invisibilização (JATOBA, 2002).

Entretanto, esse modelo está, ao poucos, sendo substituído por pequenas aglomerações de casas ao redor de regiões que ofereçam melhorias mínimas nas condições de vida da comunidade, como escolas, estradas, posto de saúde ou energia elétrica. O professor Jaime Almeida, em um artigo de 2005 a respeito dos Kalungas, já antevia que isso ocorreria inevitavelmente:

Com a introdução dos equipamentos de educação formal e de saúde, construções prediais, e as estradas de rodagem pelo Estado haverá naturalmente modificação substantiva naquela configuração espacial (ALMEIDA, 2005).

Assim, a pesquisa conta com uma comunidade com distribuição espacial tradicional (Vão de Almas), e um povoado com agrupamento espacial moderno, em forma de povoado (Engenho II). Com o objetivo de melhor contextualizar cada uma das localidades, segue abaixo uma breve descrição de cada um dos dois núcleos estudados. 
Tabela 7 - Distribuição dos domicílios, segundo o povoado. Comunidade quilombola Kalunga. "VA" indica as comunidades pertencentes ao Vão de Almas (Adaptado de SEPPIR/Fubra, 2004)

\begin{tabular}{|c|c|c|}
\hline Obs. & Povoado & Número de Domicílio \\
\hline 1 & Engenho II & 77 \\
\hline 2 & Maiadinha & 63 \\
\hline 3 & Diadema & 50 \\
\hline 4 & Sucuri & 45 \\
\hline 5 & Ribeirão & 41 \\
\hline 6 & Tinguisal & 37 \\
\hline 7 & Riachão & 35 \\
\hline 8 & Limoeiro & 25 \\
\hline 9 & São Pedro & 25 \\
\hline 10 & Taboca & 25 \\
\hline 11 & Barra & 24 \\
\hline 12 & Vargem Grande (VA) & 23 \\
\hline 13 & Buritisinho (VA) & 19 \\
\hline 14 & Capela (VA) & 19 \\
\hline 15 & Prata & 19 \\
\hline 16 & Areia (VA) & 18 \\
\hline 17 & Ema & 18 \\
\hline 18 & Congonha & 15 \\
\hline 19 & Curriola & 15 \\
\hline 20 & Gameleira (VA) & 14 \\
\hline 21 & Boa Sorte (VA) & 13 \\
\hline 22 & Buriti (VA) & 13 \\
\hline 23 & Côco (VA) & 13 \\
\hline 24 & Lagoa (VA) & 12 \\
\hline 25 & Vasantão (VA) & 12 \\
\hline 26 & Volta do Canto & 12 \\
\hline 27 & Carolina & 11 \\
\hline 28 & Córrego da Serra (VA) & 11 \\
\hline 29 & Altamira & 10 \\
\hline 30 & Bom Jardim & 10 \\
\hline 31 & Córrego fundo (VA) & 10 \\
\hline 32 & Pedra Preta (VA) & 10 \\
\hline 33 & Vão das Almas (VA) & 10 \\
\hline 34 & Contenda & 9 \\
\hline 35 & Gonçalo Vão de Almas (VA) & 9 \\
\hline 36 & Parida (VA) & 9 \\
\hline 37 & Capivara (VA) & 8 \\
\hline 38 & Mochila (VA) & 8 \\
\hline 39 & Terra Vermelha (VA) & 8 \\
\hline 40 & Buriti Velho (VA) & 7 \\
\hline 41 & Curral da Taboca & 7 \\
\hline 42 & Barrinha & 6 \\
\hline 43 & Bonito & 6 \\
\hline 44 & Fazendinha & 5 \\
\hline 45 & Jurema (VA) & 5 \\
\hline 46 & Redenção & 5 \\
\hline 47 & Salinas & 5 \\
\hline 48 & Capim Puro/Puba (VA) & 4 \\
\hline 49 & Paiol de Roda (VA) & 4 \\
\hline 50 & Pé de Morro & 4 \\
\hline 51 & Ursa & 4 \\
\hline 52 & Taboquinha (VA) & 3 \\
\hline 53 & Boa esperança & 2 \\
\hline
\end{tabular}




\begin{tabular}{lcc}
\hline 54 & Calda & 2 \\
55 & Córrego do Forte (VA) & 2 \\
56 & Faina & 2 \\
57 & Chapadinha & 1 \\
58 & Córrego de Areia (VA) & 1 \\
59 & Fazenda Gerais & 1 \\
60 & Mato Grosso & 1 \\
61 & Pequizeiro (VA) & 1 \\
62 & Sussuarana & 1 \\
\hline
\end{tabular}

\subsubsection{Engenho II}

A comunidade Engenho II, está localizada a menos de $30 \mathrm{~km}$ de cede do município de Cavalcante. Apesar de não pavimentada, a estrada que leva ao povoado é de fácil acesso, e a distância pode ser vencida em aproximadamente 40 minutos. Em 2004, a comunidade contava com 77 famílias (Tabela 7). Atualmente esse número quase dobrou, chegando em 2013, segundo Costa (2013), à soma de 125 agrupamentos familiares, totalizando aproximadamente 630 habitantes (Tabela 3, p.43). Apesar da maioria dos moradores serem nascidos na própria região, é comum que uma parcela da população (aproximadamente $30 \%$, de acordo com dados de Velloso, 2007) seja oriunda de outras regiões do território, como demonstra a Figura 15.

\section{NÚMERO DE FAMÍLIAS SEGUNDO A LOCALIDADE}

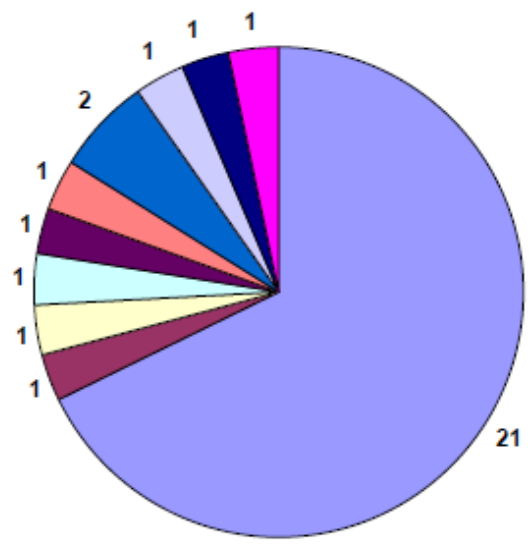

$$
\begin{aligned}
& \square \text { Engenho } 2 \\
& \square \text { Água Fria } \\
& \square \text { Chapada Piteira } \\
& \square \text { Formosa } \\
& \square \text { Cavalcante } \\
& \square \text { Vão do Muleque } \\
& \square \text { Vão de Almas } \\
& \square \text { Vão dos Órfãos } \\
& \square \text { São Domingos } \\
& \square \text { Não respondeu }
\end{aligned}
$$

Figura 15 - Número de famílias segundo a localidade de nascimento. Engenho II. Total de 31 entrevistados. (Fonte: VELLOSO, 2007)

A aglomeração de casas que atualmente formam o núcleo da comunidade possui origens recentes. Até pouco tempo, antes da década de 1980, a casas estavam distribuídas ao longo das margens dos principais rios da região. Os mapeamentos realizados por Velloso 
(2007) mostram que algumas famílias habitavam a região que hoje é destinada ao centro da comunidade, mas que a maior parte dos núcleos familiares se encontrava dispersa por outras áreas.

Essa dinâmica foi gradativamente alterada, no final da década de 1990, com a chegada da estrada que liga a região à Cavalcante, mas outros fatores, como a escola Joselina Francisco Maia (em 1985) e a especulação ilegal de terras, também tiveram forte influência sobre essa mudança. A expulsão de várias famílias de suas terras, por meio de violentas investidas dos posseiros, resultou em um número significativo de famílias destituídas de suas áreas de roçado (Baiocchi, 1999). Banidas de suas áreas produtivas, e sobre constantes ameaças, essas pessoas foram obrigadas a migrar para áreas mais seguras, mas que nem sempre ofereciam terras férteis.

Assim surgiu o agrupamento de famílias que, hoje, é chamado de Engenho II. Entretanto, existem aqueles que tendem a considerar essa comunidade como não original do quilombo Kalunga, dizendo se tratar apenas de famílias novas e recém-chegadas. Essa informação não se comprova, como mostram os dados levantados em 2007 por Velloso (2007). A pesquisadora mapeia as construções, cemitérios e ranchos da antiga distribuição espacial da comunidade, demonstrando a existência prévia dessas famílias na região. Ela mostra que, apesar da distribuição geográfica ter se alterado ao longo dos anos, os grupos familiares permanecem os mesmos.

Ainda de acordo com Velloso, no ano da sua pesquisa de campo, persistiam treze fazendas dentro do território do Engenho II, o que limitava de forma considerável as áreas livres para plantio. São elas a fazenda Choco, Paciência, Chapinha, Segredo, Bucaina, Fundão, Engenho Santo Antônio, Nova Aurora, Ave Maria, Piteira, João Rodrigues, Pequi e Maquiné. Segundo os moradores, cada fazenda teve sua origem em momentos distintos, mas as atividades de desterritorialização se concentraram, principalmente, a partir da década de 1980, com os estudos de reconhecimento da comunidade Kalunga, expansão da fronteira agrícola e turística da região.

Algumas pesquisas se aprofundaram nas questões legais e fundiárias no território Kalunga, como é o caso dos trabalhos de Siqueira (2012) e Franco (2012). O primeiro trata dos instrumentos jurídicos que estão envolvidos na questão agrária da comunidade, e o segundo trabalho aborda mais especificamente a regularização fundiária do grupo, enfocando a desapropriação das propriedades ditas particulares, que se localizam sobrepostas às terras quilombolas, abordando os atos legais que regem essas atividades. 
Ambos são frutos da Faculdade de Direito da UFG, e realizam debates atuais e pertinentes aos problemas jurídicos que a comunidade viveu e ainda vive.

De 2007 para cá, algumas das fazendas já foram indenizadas, e voltaram a ser utilizadas pelas famílias nativas. Segundo relato de um dos moradores da região, nos últimos anos as ameaças e intimidações relacionadas à questão fundiária cessaram, e mesmo as terras que ainda não foram legalmente restituídas aos Kalungas, já estão informalmente abandonadas. Uma dessas áreas que voltou a integrar os sistemas produtivos da comunidade é a Bucaina (Figura 16), que atualmente é cultivada, entre outros, pelo seu Joaquim Francisco Maia e filhos. Em seus relatos, ele contou que a área ficou muitos anos parada, devido aos "paulistas" (forma como a comunidade se refere aos posseiros), apesar de ser uma das dezessete áreas de roça com boa terra de cultura localizadas na região do Engenho II.

Entretanto, durante os anos em que as terras estiveram griladas, alguns dos agricultores optaram por trabalhar como meeiros em suas próprias terras, como alternativa à escassez de terras produtivas. Dessa forma, uma parte de tudo que produziam era destinada ao pagamento da "meia" para os fazendeiros, que haviam tomado suas terras. Outros moradores procuraram novas terras de plantio, mais longe e menos férteis, mas que não impunham relações produtivas com os "paulistas".

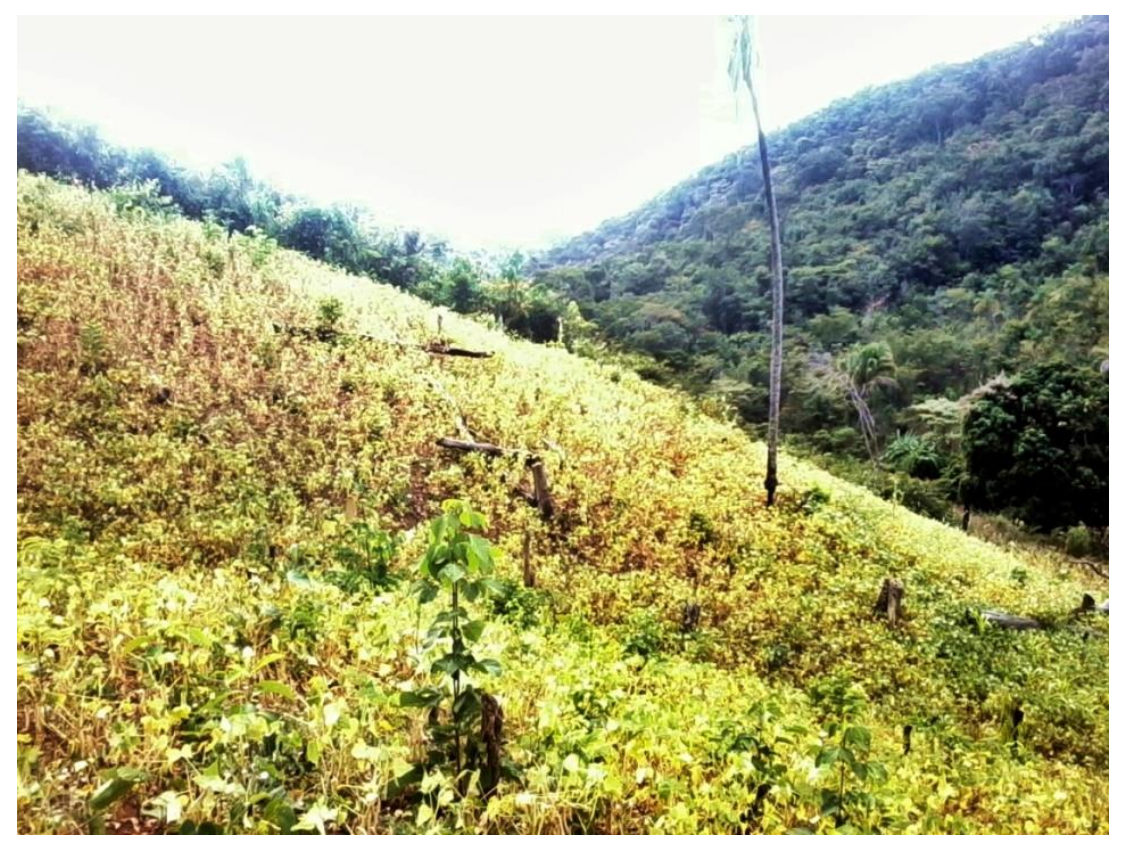

Figura 16 - Roça de toco com plantio de feijão, na Bucaina -Engenho II. (Fonte: Trabalho de campo. Maio de 2014).

Esses acontecimentos fundiários que marcaram a comunidade também deixaram seu legado na dinâmica produtiva da comunidade. O hábito adotado, antes da especulação 
fundiária na região, era de moradias relativamente próximas às áreas de roçados, e distantes das estradas. Com a aglomeração das casas que se sucedeu a isso, atualmente a moradia principal de cada família está localizada, em média, a mais de $7 \mathrm{~km}$ das roças.

No Engenho, esse percurso, da moradia à plantação, ainda é dificultado pelas serras, que tornam o escoamento da produção até as casas mais difícil. Isso se dá devido à necessidade de boas terras, terras de cultura, que geralmente estão nos vãos, áreas de depressões características das montanhas e próximas à cursos d’água, como no caso da Bucaina.

A comunidade também se localiza em uma região estratégica para o território, pois dá acesso ao Vão de Almas e ao Vão do Moleque. Os moradores dessas áreas encurtam os caminhos até as cidades, vindo a cavalo ou a pé até o Engenho, por isso Cesariano Paulino da Silva explica:

[...] Ou eles vem aqui e param porque aqui é ponto estratégico de toda a parte, não é. Aqui vem do Vão de Almas, é para aqui que vem a cavalo, é para aqui que vem do Vão do Moleque a cavalo, tem que ser aqui, queira ou não queira tem que ser por aqui. Então, aqui é o ponto aonde, tanto é que eles mesmo exigiram que a sede da Associação tem que ser aqui. O próprio Vão de Almas, o próprio Vão do Moleque aceitaram que a sede tinha que ser aqui, porque aqui é o ponto estratégico de encontro locais (VELLOSO, 2007, p. 119).

Essa comunidade também é palco de diversas pesquisas acadêmicas e projetos governamentais, e é difícil que se faça uma visita ao povoado sem que se encontre outra atividade sendo realizada, como oficinas de confecção de sabonetes, curso de panificação, curso de condutor turístico, oficinas de bordados, tecelagem ou cerâmica, projeto de hortas medicinais, hortas nos quintais, levantamento de potencial turístico, cursinhos preparatórios para o ENEM, além das pesquisas sendo desenvolvidas em diversas áreas, como ecologia, botânica, antropologia, geografia e turismo.

A constância dessas atividades desenvolvidas a partir de demandas externas, torna os seus moradores habituados a tais dinâmicas, mas também desconfiados em relação aos seus resultados. É comum observar a chegada de ônibus de instituições universitárias que descarregam grandes grupos de graduandos que, em um ritmo frenético, adentram casas e abordam moradores em busca de dados e informações para alguma nova pesquisa.

Em busca de um modelo diferente de trabalho, a presente pesquisa seguiu um tempo bem distinto de coleta de dados, agendando previamente as entrevistas, sempre depois de um período de convivência informal com as famílias, e levando em consideração os horários e dinâmicas das atividades particulares de cada família. Dessa forma, mesmo com um gasto maior de tempo e um número menor de dados, a pesquisadora acredita ter se aproximado 
de forma mais eficiente dos moradores e, assim, obtido um conjunto mais real de respostas aos questionamentos levantados ao longo do trabalho.

\subsubsection{Vão de Almas}

O Vão de Almas, diferentemente do Engenho II, não é uma vila, ou um agrupamento de casas próximas. Ele representa uma grande extensão de terra entre os municípios de Cavalcante e Teresina, que se espalha ao longo dos dois lados do Rio das Almas. Atualmente, os moradores da região rebatizaram o rio de Rio Branco, na crença de diminuir as mortes por afogamento que acorriam todos os anos no período chuvoso. Do lado oeste da Serra da Boa Vista, se encontram as comunidades do Vão do Moleque e a região do Engenho II. Ao norte, do outro lado do Rio Paranã, está a região do Vão da Contenda, no município de Monte Alegre.

Segundo dados de 2013, a comunidade (região)do Vão de Almas é composta por 215 famílias, que somadas representam 1.075 habitantes espalhados ao longo de vinte e sete localidades (destacadas na Tabela 7), na maioria das vezes representadas por pequenos agrupamentos familiares (Figura 17). Entretanto, é comum que a comunidade Capela seja identificada em alguns mapas e trabalhos como Vão de Almas, uma vez que é lá que ocorre o maior festejo da região, a Festa de Nossa Senhora D’Abadia, durante o início do mês de setembro. Para os fins da presente pesquisa, a terminologia "Vão de Almas" está sendo empregada para a região, e não para o local do festejo.

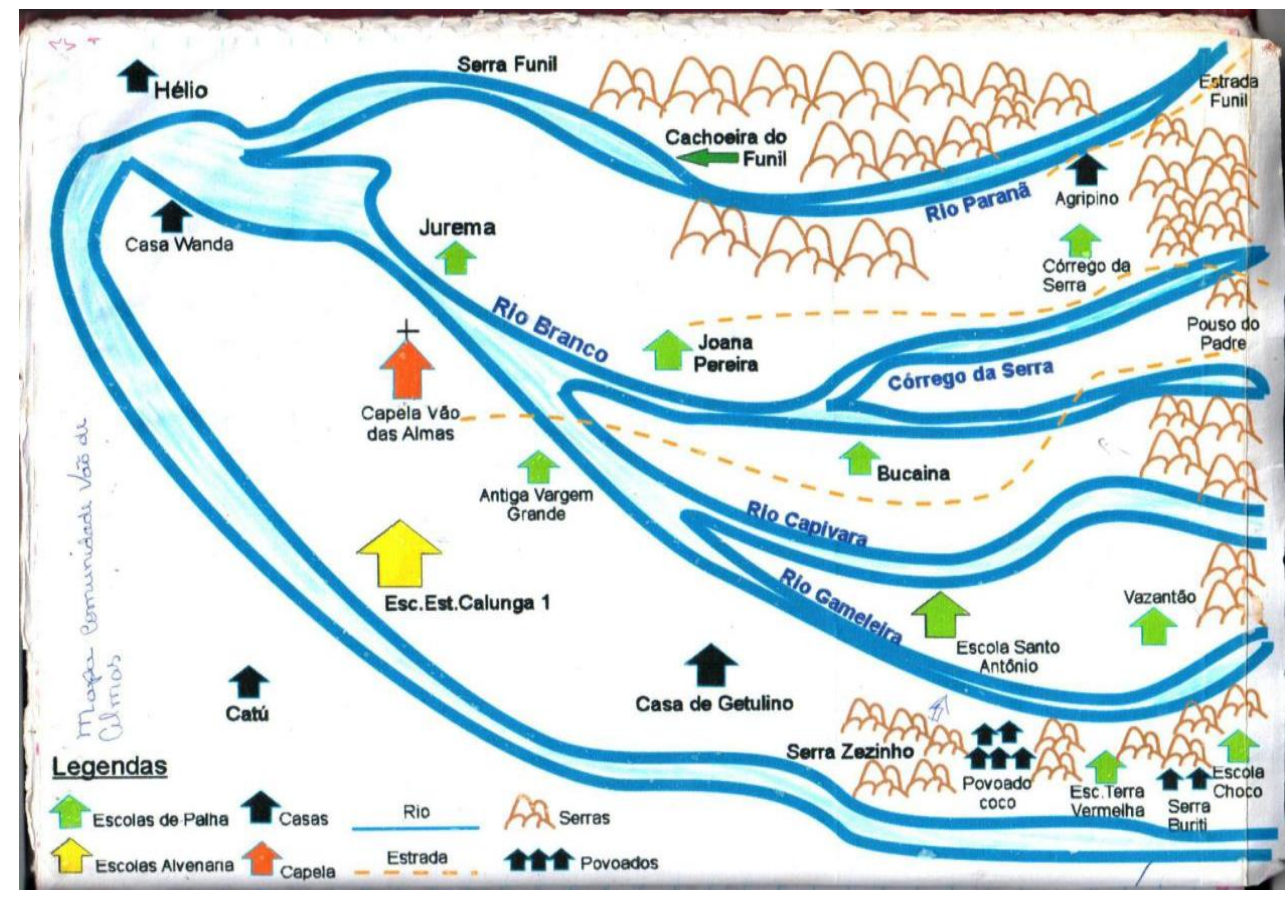

Figura 17 - Mapa da região do Vão de Almas indicando as escolas, a capela e algumas casas. Desenhado pela pesquisadora Kalunga, Wanderleia dos Santos Rosa, no ano de 2010. (Fonte: ROSA, 2013) 
Como já citado, a distribuição espacial dessa comunidade preserva o antigo padrão desenvolvido pelos quilombolas ao longo dos anos de escravidão. As casas e roças estão espalhadas ao longo do território, de forma a se tornarem invisíveis aos que transitam pelas estradas. A preservação desse modelo também possibilita aos habitantes da região manterem suas casas próximas as áreas de roçado, facilitando o escoamento da produção, que não precisa ser transportada por serras e morros até o local onde será processada ou armazenada, como no caso do Engenho II.

Assim como a maior parte das comunidades do território Kalunga, a região do Vão de Almas também não possui energia elétrica, água encanada ou rede de esgoto, com exceção de algumas aglomerações familiares próximas a rodovia GO-118. O vão conta com sete escolas de ensino fundamental, sendo seis municipais e uma estadual (Figura 17) (ROSA, 2013). São elas a Escola Vazantão, Bucaina, Kalunga I, Jurema, Joana Pereira, Terra Vermelha e Córrego da Serra.

Entretanto, a região não foi contemplada com nenhum colégio de ensino médio, o que acarreta diversas complicações sociais e logísticas para a comunidade, como a migração temporária ou permanente das famílias para as cidades mais próximas ou a concessão da tutela informal e temporária das crianças em idade escolar para familiares ou compadres que vivam nos centros urbanos, como já citado. Fazem parte do corpo docente da região dezesseis professores, sendo que quatro possuem segundo grau completo, dois completaram a graduação e dez estão cursando Licenciatura em Educação do Campo (dados de 2013). A situação do ensino é mais bem explicitada pela pesquisadora, e secretaria de Igualdade Racial de Cavalcante, Wanderleia dos Santos Rosa, que relata:

[...]Em Vão de Almas o ensino é ofertado de forma multisseriada em praticamente todas as escolas do $1^{\circ}$ ao $5^{\circ}$ ano do ensino fundamental. $\mathrm{O}$ ensino regular é ofertado pelo Estado em parceria com o município e compreende do $6^{\circ}$ ao $9^{\circ}$ ano do Ensino Fundamental. Concluídas essas fases de ensino a maioria dos jovens não tem a menor condição para continuar os estudos, pois ali não é ofertado o ensino médio. [...] Impedidos de dar continuidade à vida escolar alguns jovens costumam sair para trabalhar nas fazendas ou lavouras mais próximas, outros migram para Brasília e Goiânia com expectativas de estudar e arranjar outro tipo de trabalho. Isso é um prejuízo para esses jovens, pois muitas vezes se tornam presas fáceis para o mundo das drogas nas grandes capitais do Brasil (ROSA, 2013, p. 22).

A região também não conta com nenhuma infraestrutura relacionada ao sistema de saúde, e todas as demandas hospitalares precisam ser resolvidas em Cavalcante, Teresina ou Campos Belos. Para se tratarem, os moradores do Vão de Almas necessitam caminhar longas distâncias até as vias principais, e depois pagarem de vinte a trinta reais pelo "carro de linha" (caminhão adaptado para transportar pessoas na caçamba) que os leva para as 
cidades próximas. Contudo, a estrada que dá acesso ao vão é uma das mais perigosas da região (

Figura 18), e mesmo com as melhorias recentes, continua sendo ideal apenas para carros com tração $4 \times 4$, o que gera acidentes quase todos os anos. É raro encontrar um morador da região que não tenha sofrido com isso, como conta Percília dos Santos Rosa:

\begin{abstract}
A gente fretou um caminhão pra levar a gente em Cavalcante, reuniu muitas pessoas, eram 56 pessoas. Quando eu vi o caminhão, falei que não ia aguentar, mas o pessoal falou: "não, vai aguentar." E ai nós pegávamos vinte reais de passagem para ele. Aí, quando foi pra vencer o topinho da serra, o caminhão voltou de ré, mas Deus passou a mão na cabeça do povo que todo mundo silenciou. Ele bateu a traseira num pé de pau e virou atravessado na estrada, e aí virou uma confusão danada! Tinha mulher buchuda, tudo tinha dentro desse caminhão. A mulher buchuda estendeu a mão pra mim, então eu segurei a mão dela. Quando o caminhão virou, eu estava segurando na mão dela e ela na minha; aí também foi rapidinho, passou e virou só o poeirão. [...] Essa estrada é muito perigosa, muito perigosa, agora já está mais ou menos, melhorou um pouco. A gente tem que viajar com muito cuidado, muita atenção. Antes nós vínhamos de burro, um por aqui, um por lá, um dia, dois dias, três dias andando a pé, andando a cavalo. Hoje não, hoje mesmo perigosa já favorece um bocado as pessoas que sai cedo e de tarde já está aqui de volta; sai de tarde e de manhã cedo está aqui de novo, mesmo pagando (MAGALHÃES, 2013, p. 25).
\end{abstract}

Mesmo assim, problemas mais sérios de saúde são encaminhados pelo município para Brasília ou Goiânia, o que demanda das famílias dinheiro de passagem e hospedagem durante todo o tratamento do enfermo. Além disso, na época das águas, os rios sobem de nível, deixando seus moradores isolados por vários dias, a depender da frequência das chuvas. A ausência de pontes e manutenção nas estradas é uma das mais recorrentes reclamações dos Kalungas da região, sendo constante pauta política em períodos eleitorais, mas nada tem sido efetivamente feito em relação a isso nos últimos anos.

Os moradores da região têm por hábito tomar banho nos rios próximos às casas, uma vez que a água é levada até as residências em baldes e bacias. Mesmo as famílias que conseguiram adquirir motores a gasolina para bombear a água até os quintais, ainda mantem o costume, já que assim podem economizar em combustível. A dinâmica de "descer" até os cursos d'água também é empregada para a lavagem de utensílios domésticos e roupas, ao final de cada dia de atividades domésticas. Nos festejos, com grande número de participantes, o comportamento habitual é o mesmo (

Figura 19).

Os dados coletados para este trabalho foram obtidos a partir de entrevistas realizadas com famílias da região norte do vão, logo abaixo do Rio Paranã, entre os rios Capivara, 
Pedra Preta e Gameleira. As visitas de campo, a essas comunidades, ocorreram entre os meses de agosto e novembro de 2014. As visitas foram feitas durante o período da seca, a fim de se evitar a estrada quando da chegada das chuvas. O transporte até as moradias ocorreu de diferentes formas ao longo dos meses, alternando-se entre caronas com a prefeitura, pesquisadores e turistas, "carro de linha" e frete de carro $4 \times 4$ no período das festividades e das primeiras chuvas.

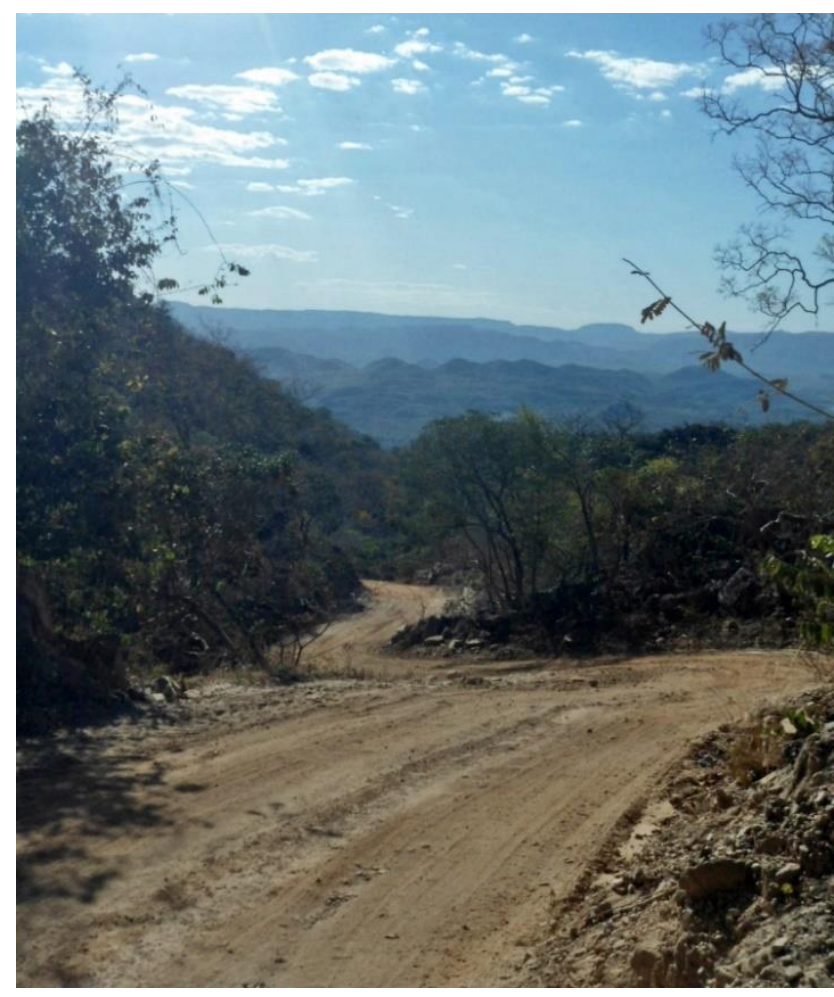

Figura 18 - Estrada que dá acesso às comunidades do Vão de Almas (Fonte: Trabalho de campo. Agosto de 2014)

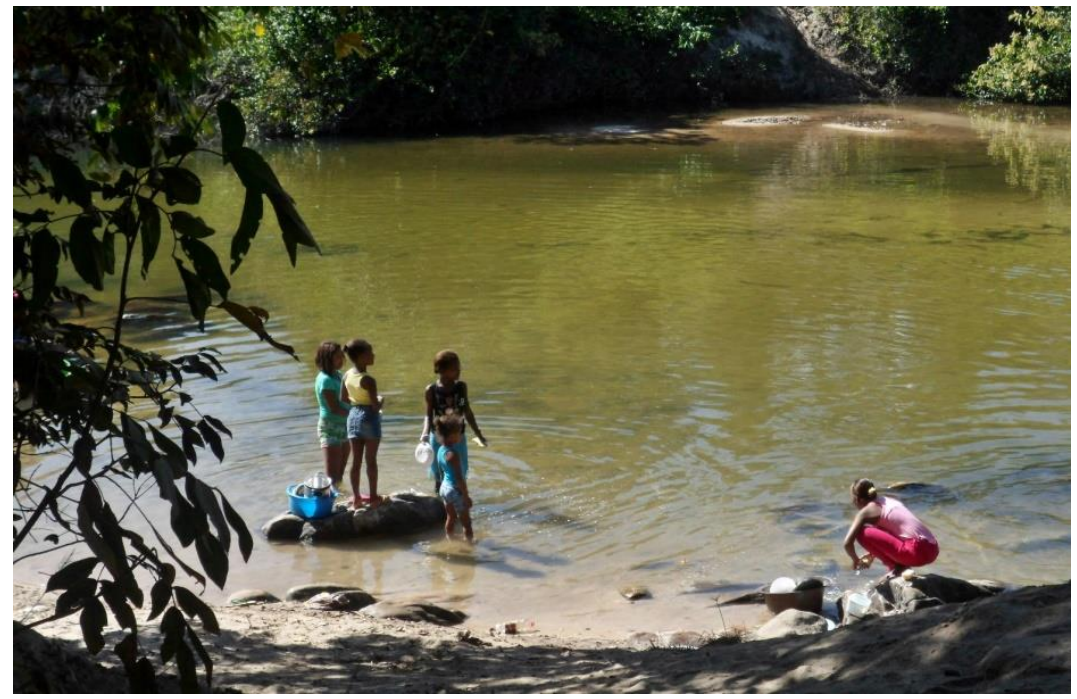


Figura 19 - Mulheres e crianças tomando banho e lavando utensílios domésticos no rio, durante o festejo de Nossa Senhora D’Abadia, no Vão de Almas. (Fonte: Trabalho de campo. Agosto de 2014)

Infelizmente, o Vão de Almas é uma região pouco contemplada com estudos acadêmicos e levantamentos estatísticos, gerando uma carência de dados socioeconômicos se comparada com a comunidade Engenho II. A região também carece da criação de mapas mais detalhados, que realmente indiquem as diferentes comunidades, uma vez que os existentes não mostram nem metade das localidades que compõem o vão.

Dito isso, espera-se ter criado um retrato adequado das duas localidades estudadas, a fim de que se possa prosseguir com os dados de campo e as reflexões que esses possibilitaram. A seguir, tentar-se-á descrever a complexa cadeia produtiva que forma os sistemas alimentares da comunidade quilombola Kalunga, dividindo-a nos processos e atividades que ocorrem: a) nas roças, b) nas hortas e pomares, c) nas matas/Cerrado e d) nas cozinhas. 


\section{CAPÍTULO 3 - SISTEMA ALIMENTAR DA COMUNIDADE KALUNGA}

É nas atividades mais diretamente relacionadas com a sobrevivência da espécie humana, como a reprodução e a alimentação, que a natureza e a cultura se encontram de maneira mais forte. Por intermédio da alimentação, comum a todos os seres vivos, os humanos não só satisfazem as suas necessidades mais básicas, mas também expressam a sua cultura. Ela se revela no cultivo de espécies alimentícias, nas formas de cozimento, preparação, corte e tempero.

"Muito mais do que um ato biológico, a alimentação humana é um ato social e cultural" (MACIEL, 2004) ela envolve escolhas, símbolos, gestos e combinação de ingredientes. Cozinhar é o espaço compartilhado entre memória e identidade (PETRINI, 2009), e como tal define não só o que se come, mas aquele que come. É um identificador de grupos e pode se transformar em marcador identitário, símbolo de uma identidade reivindicada (MACIEL, 2005)

Seja por meio da agricultura ou do extrativismo, espécies alimentícias e medicinais foram selecionadas durante milhares de anos, em um delicado esquema de protocooperação entre homem e natureza. Estima-se que na atualidade sejam cultivadas menos de 2,5\% das espécies antes conhecidas no mundo. Junto com esse desaparecimento da agrobiodiversidade ocorre a perda de um patrimônio valioso de saberes.

A recomendação da Organização das Nações Unidas para Alimentação e Agricultura (FAO) para que as pessoas prestassem mais atenção em todos os níveis dos sistemas alimentares mundial, regional e local, visa garantir a segurança alimentar e nutricional das comunidades, evitando desequilíbrios que surgem da invisibilidade dos atores que se espalham ao longo de suas redes. Dessa forma, pode-se partir da seguinte definição, que ajuda a compreender o que compõem esses sistemas:

Sistemas Alimentares são o meio ambiente, as pessoas, as instituições e os processos pelos quais os produtos agrícolas são produzidos, processados e levados aos consumidores (FAO, 2013).

A nível mundial, essas cadeias de relações estabelecidas a partir do consumo de alimentos possuem dimensões globais, interconectando uma grande gama de países e culturas em um mesmo produto. Quando se ajusta o foco para a escala local, percebe-se que uma menor quantidade de atores estão envolvidos, mas a complexidade dessas redes de relações não são menores. 
As seções seguintes tentarão tratar dos diferentes elementos que compõem o sistema alimentar Kalunga, aqui separado por locais dentro da comunidade. Essa divisão é arbitrária e teve por finalidade facilitar a descrição dos elementos físicos e simbólicos, e não constitui barreiras reais entre os atores envolvidos nesses sistemas. As categorias criadas foram: as roças; os quintais, hortas e pomares; o Cerrado; e a cozinha.

\subsection{AS ROÇAS}

A pesquisa realizada pela SEPPIR e pala Fubra, no ano de 2004, apontou a manutenção da base econômica Kalunga, que já havia sido descrita por Baiocchi (1999). Esses dados apontam que $73 \%$ das famílias ainda obtém parte dos seus recursos das roças (SEPPIR/Fubra, 2004), uma vez que a comunidade tem como característica fundamental a agricultura de subsistência, a criação de bovinos, suínos e aves, o extrativismo de frutos do cerrado, e o cultivo de frutas e verduras nas hortas e pomares (UNGARELLI. 2009). O modo de produção predominante é o de subsistência, baseado na agricultura em pequenas áreas, sem a utilização de maquinário ou de insumos químicos.

Assim como outras populações tradicionais brasileiras, os Kalungas se utilizam de áreas com terras mais férteis, muitas vezes próximas a cursos d'água, para produzirem alimentos básicos para seus sistemas alimentares. Esse tipo de solo, chamado por eles de "terra de cultura" varia de localidade para localidade, contudo as áreas próprias para cultivo não ultrapassam mais que $35 \%$ do seu território (BAIOCCHI, 1996). Além disso, o relevo extremamente acidentado, escolhido outrora como refúgio, torna a logística agrícola uma atividade elaborada, que envolve também a localização das moradias e a forma de transporte dos produtos.

\subsubsection{Localização}

Como já foi citado, a dinâmica tradicional de distribuição espacial da comunidade se caracteriza por amplos espaços desertos e a invisibilidade das habitações. Esse modo de viver permitia que cada família escolhesse uma determinada área fértil e se instalasse junto a ela. Algumas vezes, as casa eram construídas junto aos roçados, outras, a uma distância segura da água a fim de evitar transtornos típicos da estação das chuvas. Entretanto, essas distâncias entre roças e casas sempre foram marcadamente curtas, o que proporcionava uma interação prática é simples com os produtos agrícolas cultivados. 
Dessa forma, permitia-se que as famílias produzissem e processassem seus alimentos a uma distância relativamente curta de suas casas, facilitando o transporte e estocagem dos mesmos. Ainda hoje, esse é o padrão espacial encontrado na região do Vão de Almas, onde cada família mora junto a sua área de roça, mantendo distâncias de no máximo $2 \mathrm{~km}$. Essa escolha também implica em uma maior proximidade com os rios, córregos e grotas, mas por estarem localizados em um vão, os declives são comumente menores, possibilitando que as moradias se instalem de forma segura.

A dinâmica que se impôs aos moradores do Engenho II difere da citada, uma vez que a grilagem de suas terras, ao longo de quase trinta anos, os forçou a uma aglomeração espacial destoante do modelo adotado à época. Mesmo com a devolução das terras griladas as mãos dos antigos donos, o padrão urbanístico não retornou a sua antiga forma, criando uma distância, entre moradias e roças, de em média $7 \mathrm{~km}$, muito maior que a habitual, como demonstrado no mapa da pesquisadora Velloso, de 2007 (Figura 20).

Outro fator geográfico a se levar em consideração é o relevo tipicamente acidentado das regiões de terras de cultura na área do Engenho. Ao contrário das roças do Vão de Almas, que são de fácil acesso uma vez que se chegue ás casas, no Engenho elas estão localizadas em meio as serras que circundam a comunidade, tornando o acesso complicado e cansativo. Entretanto, a permanência desse novo modelo não pode ser atribuída unicamente aos acontecimentos passados, uma vez que atualmente existem outros motivos sociais que levam as famílias a optarem pelo "vilarejo", como a chegada da escola, da energia elétrica, do turismo e do posto de saúde.

A disposição espacial das roças influi sobre as escolhas produtivas, tanto quanto o tipo de solo da região. O que poderia não ser uma razão aparente para agricultores equipados com tratores, estradas e caminhões, é um forte determinante sobre os padrões agrícolas Kalungas. A farinha de mandioca, produto símbolo do escambo Kalunga, tem tido sua produção gradativamente reduzida na comunidade Engenho II, como relata uma senhora local:

Aqui é assim, às vezes tem às vezes não tem, mais a gente produz a farinha (de mandioca), mas tem feito menos, não é. O Vão (de Almas) é melhor pra isso, não é bom pra arroz, mas bom pra farinha. Aqui é difícil de mais trazer a mandioca, só no lombo do animal ou nas costa mesmo. Ai o povo não quê, não é mesmo. Quando tem animal traz, se não tem às vezes estraga na roça. Eu mesmo compro deles lá, lá do vão. É farinha boa, boa mesmo (Moradora do Engenho II).

O povo lá não quer é subir com as raiz nas costa, mas lá dá mandioca bem, lá no engenho o que planta dá. Lá é ruim por que eles planta nuns meio de serra que pra chegar é difícil, mas se coloca um forno lá no rancho da roça até dá, não dá (Morador do Vão de Almas). 


\section{ENGENHO || TERRाTORIO KALUNGA}

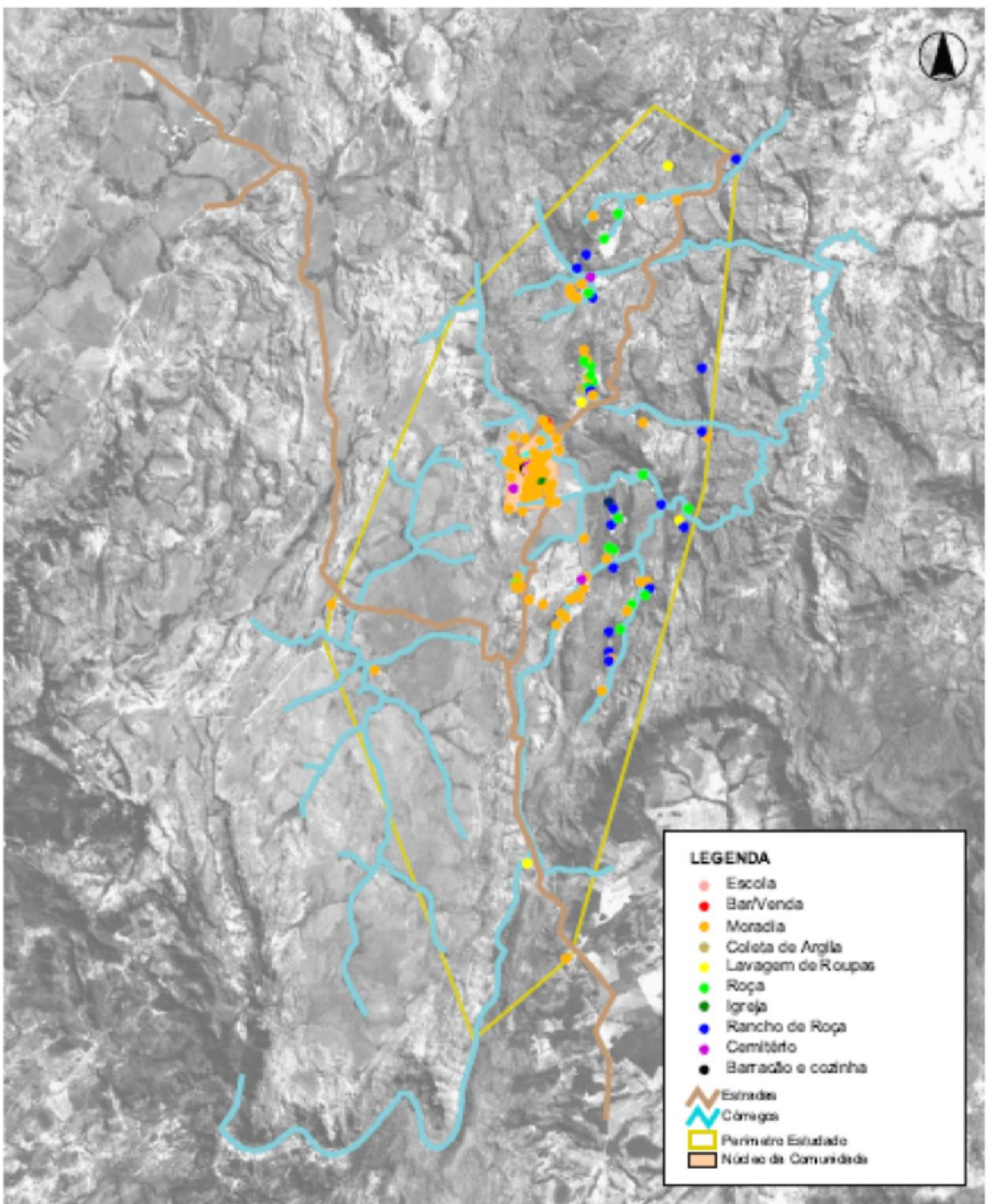

Mapa 3.8 - Uso e Ooupaģăo do Terribrio

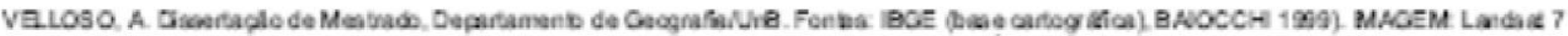

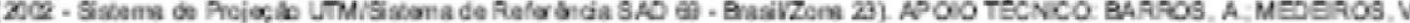

\begin{tabular}{llll}
\hline 3 & 3 & $\mathrm{Km}$ & $1: 150.000$
\end{tabular}

Figura 20 - Uso e ocupação do território na comunidade do Engenho II, mostrando a localização das áreas de roça em relação ao núcleo atual da comunidade (Fonte: VELLOSO, 2007). 
Cabe ressaltar que a comunidade do Engenho segue produzindo a farinha de mandioca para autoconsumo, e continua se utilizando da mandioca na alimentação diária. Entretanto, o volume da produção foi drasticamente reduzido, fazendo que exista pouco excedente produtivo para ser vendido ou trocado nas cidades, além de, algumas vezes, faltar para o próprio uso doméstico das famílias. Observa-se nessa situação, que a dinâmica espacial da comunidade é mais significativa na hora da escolha da cultura da mandioca, do que o tipo de solo ou das condições climáticas locais. Ou seja, a alteração da disposição geográfica das famílias também gerou uma alteração do padrão alimentar e econômico da comunidade.

Essa alteração ocorre especificamente com a colheita da mandioca, uma vez que a raiz bruta, antes de ser processada, é difícil de ser escoada para a casa de farinha por conta de seu peso e volume. Algumas soluções podem ser propostas para esse novo modelo, mas a alternativa que vem sendo adotada pelos moradores do Engenho II, tem sido a abertura de estradas próximas ás áreas de cultura, a fim de facilitar o escoamento da produção sem a necessidade de animais de carga.

\subsubsection{Técnicas, Manejo e Equipamentos}

A tecnologia agrícola empregada nas roças Kalungas das duas localidades é a agricultura itinerante de corte e queima, regionalmente conhecida como roça de toco, pousio ou coivara. Essa técnica remete a um conhecimento indígena milenar, que foi assimilado pelas populações remanescentes durante o período da colonização (ADAMS, 2000). Ele consiste na derrubada e queima da vegetação, seguido de um período de cultivo que acarreta no declínio da fertilidade do solo, seguido de um período de pousio para a recuperação da fertilidade (SIMINSKI e FANTINI, 2007). O trecho a seguir explica, nas palavras de um dos moradores do Engenho II, essa técnica:

Roça de toco, toda vida foi roça de toco aqui nunca num teve roça arada, não! Ou é na boca da enxada, na foice, no machado. Nóis faz um acero em volta pro fogo não sair, porque não pode. Ai nóis faz a roça, planta ela com três ano, quatro, cinco, até seis ano planta, larga essa e faz outra, com pouco tempo aquela que largou já ta capoeirão, já ta de volta. Volta de novo, por que às vezes tem um estirão de mata, aí vai roçando, vai rompendo, vai rompendo, aí vai deixando pra traz as capoeiras, quando termina, lá na frente já pode volta cá em baixo que já tá no ponto de começá de novo (UNGARELLI, 2009).

O período de uso das áreas varia em cada região do território nacional, de acordo com o tipo de solo, vegetação e cultura. Nas comunidades estudadas esse tempo não é muito diferente de outras regiões (SIMINSKI e FANTINI, 2007), sendo em média de duas ou quatro colheitas de mandioca, o que equivale dizer de quatro a oito anos. O período de pousio, contudo, pode variar bastante de acordo com necessidade de terras. O tempo 
mínimo citado ao longo das entrevistas foi de doze anos em regiões com maior pressão populacional, até cinquenta anos ou mais, em áreas com abundancia de terras produtivas. Entretanto, todos os entrevistados estimaram que o tempo mínimo de descanso da terra era algo entre 12 e 20 anos, a depender do tipo de solo.

A queima das parcelas de terra é precedida pela confecção dos aceiros, que tradicionalmente são realizados a partir da retirada da vegetação circundante com o auxilio de enxadas. Essa atividade é habitualmente realizada pelos membros do núcleo familiar do agricultor, e ocorre nos dias que antecedem a queima. As regras e procedimentos empregados na colocação do fogo não foram bem compreendidas pela pesquisadora, uma vez que a diversidade de discursos a respeito dos mesmo apresentavam informações conflitantes. Esse conflito entre os relatos acerca do fogo pode estar relacionado com as atuais politicas públicas relacionadas ao tema, e carece de uma pesquisa mais aprofundada.

Percebe-se que a visão negativa acerca do fogo já está embutida em algumas falas, principalmente nas dos moradores da comunidade do Engenho, que recentemente adquiriu seu próprio corpo de brigadistas. Opondo-se a isso, encontramos no Vão de Almas, falas que indicam um uso completamente diverso do fogo, e que parece remeter às técnicas tradicionais do grupo. Seguem-se alguns trechos desses discursos:

\begin{abstract}
Assim, pra mim devia de ter menos queimada, antes tinha muito fogo descontrolado, que o povo botava e não dava conta de segurar. [...] $O$ que tem mais é a queimada de pasto, pra fazer pasto. Acho que devia ter menos. [...] Meu pai me ensinou que até julho ainda dá pra botar fogo sem medo. Ele bota, mas na brigada a gente aprende que deve ser só até junho (Morador do Engenho II).
\end{abstract}

A gente queima no final de agosto (pra fazer roça), início de setembro. A agua ta pouca agora, só ta molhando em novembro, ai tem que queimar no final de agosto. Antes chovia antes, ai nos podia queimar antes.[...] A gente vigia o céu, quando começava a nublar sabe que pode limpar tudo (queimar) (Morador do Vão de Almas).

É possível que essas contradições sejam oriundas de diferenças culturais recentes, estabelecidas entre essas duas comunidades, mas também podem refletir diferenças climáticas e pedológicas das duas regiões. Carecendo de dados que possam elucidar essas questões, a presente pesquisa não se aprofundará das dinâmicas da gestão do uso do fogo da comunidade.

Os equipamentos tipicamente utilizados nas roças são a enxada, a foice e o machado. Uma inovação que tem sido adotada pelos agricultores, em relação as ferramenta, é a chamada "matraca" ou plantadeira, utilizada no plantio do arroz e do milho para a introdução das sementes de forma dosada no solo. Essa novidade, muito simples e barata, tem 
proporcionado benefícios e facilidades para os agricultores Kalungas, que puderam otimizar a etapa do plantio, sem a descaracterização do seu plantio artesanal.

Com a finalidade de vigiar as roças contra os pássaros, próximo aos meses de colheita, os membros das famílias se revezam na utilização dos estilingues, bodoques (similar a um arco-e-flecha com pedras) e fundas (atiradeira de couro), a fim de espantar os animais. Esses equipamentos, também utilizados como brinquedo pelas crianças, são manejados por toda a família, como relata o morador do Vão de Almas:

No final dos três meses pra quatro meses nós começa a vigiar. Lá é nós tudo que vigia (a roça). Na casa é todo mundo, é mulher, é menino, é todo mundo. Um tem que sair pra ali o outro tem que ficar lá na roça. [...] Nós fica lá tangendo os passarinhos pra num comer. (Usa) estilingo, bodoque, funda... nós usa tudo pra defender (Morador do Vão de Almas).

Entretanto, em duas das roças visitadas na localidade do Engenho II, observou-se a presença de rojões e fogos de artificio nos ranchos, que possuem a mesma finalidade das ferramentas citadas anteriormente. Entretanto, a utilização desses artefatos com a finalidade de espantar os pássaros, causa grande estresse a esses animais, que muitas vezes morrem só pelo barulho gerado, como foi relatado pelo informante presente.

\subsubsection{Cultivos e Variedades}

Os principais cultivos das roças Kalungas foram listados por diversas pesquisas (BAIOCCHI, 1999; VELLOSO, 2007; UNGARELLI, 2009), e sempre apontam para a tríade, tipicamente americana, de mandioca, feijão e milho (KATZ, 2009). Contudo, essa dinâmica vem se alterando, com a presença crescente do arroz, que já surge, predominantemente, em todas as listagens. Essa mudança pode ser confirmada pelo relato de uma matriarca da localidade de Engenho II:

Antes, com eu ainda menina, nós comia mais milho do que arroz, era todo mundo desse jeito. Também tinha mais tipo, variedade muita. Um branco do caroço grande, outro vermelho. Diferente desse ai (Moradora do Engenho II).

Os cultivos mais citados são a mandioca, o feijão, o arroz, o milho, a abóbora, o gergelim e a cana, mas dados de 2004, que mostrando a porcentagem de cada variedade principal, já indicam algumas mudanças. A mandioca fica em primeiro lugar, como em todas as referências, estando presente em $91,34 \%$ das roças. Em seguida vêm o arroz, a abóbora e o milho, como indicado abaixo: 
Tabela 8 - Distribuição percentual dos domicílios, segundo a cultura de subsistência. Comunidade Quilombola Kalunga. (Fonte: SEPPIR/Fubra, 2004)

\begin{tabular}{cc}
\hline Cultura & Porcentagem que possui \\
\hline Mandioca & $91,34 \%$ \\
Arroz & $90,63 \%$ \\
Abóbora & $89,32 \%$ \\
Milho & $87,17 \%$ \\
Banana & $73,19 \%$ \\
Batata doce & $72,12 \%$ \\
Cana & $65,24 \%$ \\
Feijão & $53,26 \%$ \\
Horta & $19,48 \%$ \\
\hline
\end{tabular}

A diversidade de variedades agrícolas, conhecida como agrobiodiversidade ou biodiversidade agrícola, é aquela da qual o ser humano depende para "obter alimentos, combustíveis e fibras, incluindo plantas, animais e outros organismos" (CANCl, 2006) e que se caracteriza pelo intenso manejo (CROMWELL e COOPER, 2003). Na comunidade Kalunga ela se faz extremamente perceptível em todas as roças. Abaixo segue uma lista com as principais espécies cultivadas (Tabela 9), averiguadas em campo, e suas diversidades intraespecíficas.

Tabela 9 - Espécies e variedades mais encontradas nas 29 roças visitadas (Fonte: Trabalho de campo. Jan/Out de 2014)

\begin{tabular}{|c|c|c|}
\hline Espécie & $\mathrm{n}^{\circ}$ de Variedades & Nome das variedades observadas \\
\hline Mandioca & 8 & $\begin{array}{l}\text { Marelinha, Manteiga, Castelo branco, Castelo preto, Aipim } \\
\text { branco, Vindoura, de Fritar, Brava }\end{array}$ \\
\hline Cana & 3 & Cuba, Rajada, Caiana, \\
\hline Banana & 15 & $\begin{array}{l}\text { Naniquinha, Nanicona, Maça, Tera, Roxona, Maraínha, Angola, } \\
\text { São Tomé, Farta Família, Roxa, Pratanã, Maranhão, Prata, } \\
\text { Moça, Três Quinas }\end{array}$ \\
\hline Feijão & 14 & $\begin{array}{l}\text { De corda, Marelão (Amarelão), Feijão } 60 \text { dias, Leite, Roxinho, } \\
\text { Amarelinho, Momoninho, Manteiga, Fava, Catador, Pequeno, } \\
\text { Mucunjá, Fedegoso, Andu }\end{array}$ \\
\hline Arroz & 10 & $\begin{array}{l}\text { Milharim, Taquari, Capivara, Maranhão, Trigo, Beira Campo, } \\
\text { Marabá, Novato, Arroz de Três meses, Arroz de Quatro Meses }\end{array}$ \\
\hline Abobora & 4 & Jacarezinho, Moranga, Coração de Boi, Pescoço \\
\hline Milho & 3 & Grossélio, Sabugo Fino, Sabugo Grosso, Hibrido Vermelho \\
\hline Inhame & 2 & Pedanta, Lebança \\
\hline
\end{tabular}


Além das espécies acima citadas, ainda foram encontradas, junto às áreas de roças, as seguintes variedades mescladas às culturas principais: berinjela, mamão, algodão, fumo, quiabo, pimenta, jiló, melancia, maxixe, batata, batata-doce, amendoim e cabaça.

Apesar do grande número de variedades observadas, sabe-se que muitas outras acabaram perdendo-se ao longo dos anos. A falta de um levantamento etnobotânico detalhado torna impossível, no momento, precisar quantas, mas a partir de uma comparação com os levantamentos de campo realizados pela pesquisadora Baiocchi, na década de 1980 (mas só publicados em forma de livro em 1999), já se podem estimar algumas perdas.

No caso da mandioca, não foi possível localizar, nas vinte e nove roças visitadas, as variedades Roxinha, Castelo Cipó, Doidona Preta, Doidona Branca, Sutinga Branca, Sutinga Vermelha, Cacho de Burro, Guiado e Cacau. Em relação ao arroz, as variedades Garpa, Pratão também não foram observadas em campo, assim como as variedades de feijão Costela de Vaca, Barrigudo, Ródia de Corda e Fradinho. É possível que a ausência de algumas dessas variedades não seja real, ocorrendo apenas devido a alterações na nomenclatura popular ou devido ao número de roças visitadas, entretanto, devido a relatos dos moradores, como o que se segue, acredita-se que essa redução (ou alteração) esteja realmente ocorrendo.

Hoje nós planta um hibrido vermelho (milho), os tipos antigos não tem mais. Tinha antes um branco grande, um branco miúdo, e um vermelho e preto. Agora nós ta tentando pegar de volta essas sementes com o povo lá da feira (Feira de Troca de Sementes do Cerrado), mas é divagar (Morador do Vão de Almas).

A fala acima, juntamente com a presença de algumas sementes não crioulas (ver Tabela 9) levantam questionamentos sobre agrobiodiversidade local. O patrimônio genético presente nas variedades locais, crioulas ou etnovariedades, é a chave adaptativa que confere resiliência aos agricultores tradicionais de todo o mundo. Sua redução, ou desaparecimento, gerada pelo uso crescente das sementes selecionadas entregues pelos programas governamentais, de assistência técnica ou de apoio ao pequeno agricultor, são motivos de alerta a nível global, como já colocado por diversos autores (PELWING, FRANK e BARROS, 2008; PEREIRA, 2008; SANTILLI, 2009; PETRINI, 2009).

O sinal de alerta que se levanta com o desaparecimento de algumas variedades, não torna menor a riqueza da agrobiodiversidade averiguada nas roças Kalungas (Figura 21). Contudo, é necessário que algumas ações preventivas e paliativas sejam tomadas nesse sentido, como a criação de um banco de sementes e o estabelecimento de feiras anuais de 
troca de sementes. Iniciativas nessa direção têm sido observadas, mas ainda carecem de apoio governamental para se tornarem amplas e disseminadas no território quilombola. Um exemplo desses esforços é a Feira de Troca de Sementes e Mudas da Chapada dos Veadeiros, que vem integrando pequenos produtores, agricultores familiares, assentados da reforma agrária, agricultores tradicionais e representantes do poder público, ONGs, estudantes e pesquisadores em busca de intercâmbio de experiências e saberes.
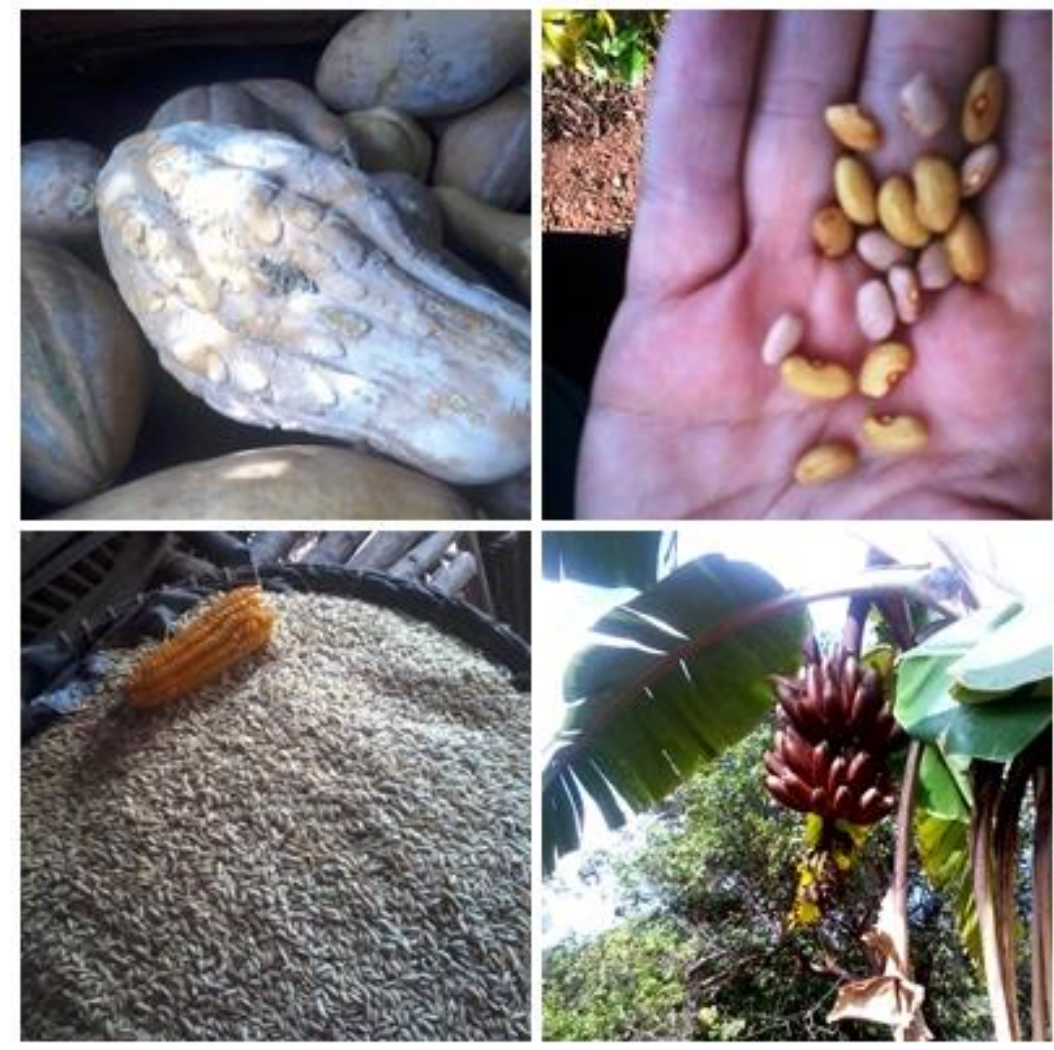

Figura 21 - Algumas das variedades de cultivos encontradas na comunidade Kalunga. Abóbora Jacarezinho; Feijão Amarelinho e Leite; Arroz Milharim, Taquari e Capivara (misturados); Banana Roxona (Fotos de Ludivine Eloy. Trabalho de Campo, maio de 2014).

A falta de projetos governamentais que salvaguardem as sementes crioulas na região, não significa que a própria comunidade não possua seus meios de trocas e conservação das variedades. Nas entrevistas realizadas foi observada uma unanimidade entre os agricultores no que diz respeito ao intercambio de variedades entre moradores da mesma região. O comportamento predominante, quando se necessita de sementes ou mudas, é a busca das mesmas junto a vizinhos e parentes próximos.

Quando nós precisa busca com vizinho daqui mesmo. O normal é guardar um tanto de um ano pro outro, mas se não tem, ou tem é quer uma diferente, ai busca aqui mesmo com um ou com outro (Morador do Vão de Almas). 
Existe uma seleção diferenciada para os grãos que servirão de sementes. Cada espécie possui o seu cuidado particular, mas citar-se-á os referentes a duas espécies fundamentais para a alimentação Kalunga: a do arroz e a do milho.

Os primeiro (cachos de arroz) a madurarem na roça, e os maiores, nós tira e separa antes de bater pra fazer semente pro outro ano. Se tem aqueles que tá forte, bonito, sem bicho, é esse mesmo que nós pega. Ai guarda direitinho no litro (garrafa PET). Não entra ar e não dá bicho. Esse nós usa pra plantar no outro ano, e se o vizinho não tem, a gente dá também (Moradora do Engenho II).

De antigamente o que nós fazia era assim: aquele milho que não bichava e que era bom, nós depois dobra, deixava na roça até depois dá uma chuva. Ai esse milho, levava pra casa e separava pra plantar no outro ano. De antes era assim que fazia. Ai tem gente que fala que se colocar no litro de coca (garrafa PET) não brota depois por que não tem ar, mas nasce sim. Eu sempre guardo assim. Mas também tem que esperar pra colher na lua boa, que não caruncha [...] Bom é na lua minguante, colhe nela que não dá bichinho nenhum, não nasce nada se guardar no litro direitinho (Morador do Vão de Almas).

Nesses dois trechos percebem-se alguns dos cuidados empregados na tarefa de escolha e preparação das sementes, essenciais à manutenção das etnovariedades e de seu patrimônio genético. Outra dinâmica Kalunga, que pode ser notada no segundo trecho, é a observação do ciclo lunar nas atividades agrícolas da comunidade. Apesar não haver uma validação científica a respeito da efetividade desses hábitos, as práticas de observação e empirismo desenvolvidas ao longo dos séculos pela comunidade, levaram a desenvolvimento desse saber que é transmitido ao longo das gerações, e ainda hoje mantido pelos agricultores mais novos.

Tem a lua certa pra colher, a lua certa pra plantar, a lua certa pra queimar. Num sei como funciona, sei que dá certo e por isso nós continua fazendo, igual ensinaram pra gente, igual os avôs faziam (Morador do Engenho II).

Agora, tratar-se-á brevemente das práticas específicas de cinco das principais culturas agrícolas Kalungas: a mandioca, o milho, o feijão, o arroz e o gergelim. Seus ciclos produtivos anuais aparecem comparativamente na Tabela 10, levando-se em consideração o período de um ano. $\mathrm{O}$ detalhamento das atividades será discutido abaixo. 
Tabela 10 - Ciclo produtivo anual de algumas variedades cultivadas no território Kalunga.

\begin{tabular}{|l|l|l|l|l|l|l|l|l|l|l|l|l|}
\hline & Jan & Fev & Mar & Abr & Mai & Jun & Jul & Ago & Set & Out & Nov & Dez \\
\hline Mandioca & & & & & & & & & & & & \\
\hline Milho & & & & & & & & & & & & \\
\hline Feijão & & & & & & & & & & & & \\
\hline Arroz & & & & & & & & & & & & \\
\hline Gergelim & & & & & & & & & & & & \\
\hline
\end{tabular}

Plantio

Colheita

\subsubsection{Mandioca}

Presente em mais de $90 \%$ das roças do território, a mandioca é um dos alimentos chave do sistema alimentar da comunidade, sendo a base da alimentação quilombola em diversas momentos. É empregada in natura nos preparos diários (como será tratado mais adiante), mas seu principal emprego é na confecção da farinha de mandioca, um símbolo do comércio e do escambo da cultura Kalunga, que remete à cultura milenar dos índios sulamericanos (KATZ, 2009).

A distinção principal, que se faz entre os tipos de mandioca, se resume a duas categorias: Brava (ou amargosa) e a Mansa (ou doce). Quando repetidamente questionados sobre os tipos dentro de cada categoria, alguns agricultores citavam algumas variedades, mas que geralmente não ultrapassavam a média de três por roça. Além disso, a maioria dos nomes citados diziam respeito a categoria das mandiocas doces, quase não havendo, atualmente, distinção entre as variedades bravas.

Como esperado, a maioria dos relatos detalhados sobre os nomes e tipos de mandiocas, estava associados aos informantes mais velhos, que demostraram grande conhecimento acerca das diferentes variedades, mesmo quando essas não estavam presentes em suas roças. As origens dessa aparente erosão do conhecimento associado às variedades de mandioca não ficaram claras ao longo da pesquisa, e carecem de maiores investigações. Contudo, supõe-se que o fato esteja relacionado à origem das manivas, que será comentado abaixo.

O processo de aquisição das manivas, outrora realizado por trocas internas às famílias e localidades, está atualmente em declínio. Apesar das novas manivas serem anualmente 
fornecidas por vizinhos ou retiradas dos quintais dos próprios moradores, elas não são mais aquelas exclusivamente quilombolas. Um dos relatos obtidos no Vão de Almas aponta que certo tempo atrás, as mandiocas "nativas" começaram a enfraquecer, levando os moradores a buscarem manivas nas cidades próximas. Não se sabe se esse processo ocorreu em todo o território, mas o fato foi confirmado pelas famílias entrevistadas no Vão de Almas, comprovando a ocorrência pelo menos nessa localidade.

O plantio da mandioca é comumente simultâneo ao do milho. Esse processo é conhecido como plantio casado ou combinado. Para os Kalungas, o momento ideal para o estacamento das manivas é logo após o início das chuvas. Contudo, os moradores da região que o período chuvoso está diminuindo, reduzindo a fartura de água no território. Por isso, relatam que antes o plantio se iniciava no final do mês de setembro, início de outubro, mas que atualmente só tem sido possível levar as manivas para as roças no mês de novembro.

Ao contrário dos outros produtos agrícolas da comunidade, a mandioca possui um ciclo longo, e está pronta para ser colhida, idealmente, de um a dois anos após o plantio. Assim, passado esse período, as raízes devem ser retiradas da terra antes do início das chuvas, á partir do mês de junho, a fim de garantir uma boa qualidade de farinha. $\mathrm{O}$ processo de produção da farinha, segundo Vizolli e colaboradores (2012), pode ser dividido em doze etapas: a preparação do solo, o plantio, a colheita, a raspagem, a lavagem, a ralação, a lavagem da massa, a prensagem, a peneiração da massa, a torração, a peneiração da farinha e o acondicionamento da farinha.

Em todas as famílias entrevistadas no Vão de Almas, essa etapas eram realizadas de forma artesanal, utilizando-se três instrumentos principais: o ralo de casca de angico (ou o ralador de metal), o tapiti (ou tipiti) e o forno de barro típico. Entretanto, na comunidade do Engenho II, é mais comum que se utilize, atualmente, um ralador à gasolina. Nessa localidade apenas duas famílias entrevistadas ainda ralavam a mandioca de forma manual.

No último ano, a produção dos entrevistados foi em média de 19 sacas no Vão de Almas, e de 6 sacas no Engenho II. Esses valores variam muito, indo de 25 sacas em famílias que visam o comercio, até 3 sacas em famílias que produzem apenas para o autoconsumo. As famílias que confeccionam a farinha em maior quantidade, para a venda nas cidades, costumam estocar um saco de farinha para o consumo familiar, e produzem mais, caso aquilo não seja suficiente para o ano. O consumo médio de farinha é de quinze litros por mês, para uma família de duas a três pessoas. 
A venda da farinha é realizada no varejo, por meio da venda de porta em porta, ou nas feiras que ocorrem esporadicamente da região. Alguns compradores pagam por saca, mas o comum é a comercialização por litro de farinha, o qual é vendido por valores entre dois e seis reais. Entretanto, o valor considerado justo pelos produtores seria sempre superior a cinco reais.

\subsubsection{Milho}

Apesar de no passado ter sido um dos três principais produtos das roças Kalungas, atualmente o milho vem perdendo espaço conforme o arroz cresce em importância devido à preferencia para novas variedades, mais resistentes e menos dependentes de água. Entretanto, mais de $80 \%$ das famílias ainda mantem sua produção que é tipicamente associada ao plantio da mandioca, e muitas vezes ao do feijão, além de outras culturas menores, como a abóbora, o quiabo e a melancia.

As variedades atualmente encontradas são o milho Grossélio, o Sabugo Fino, o Sabugo Grosso e o Hibrido Vermelho, quase todas oriundas das cidades, seja por meio de compra ou distribuição da CONAB por meio da Associação. As espécies crioulas foram aparentemente perdidas, como o caso do milho branco grande, o milho branco pequeno e o milho vermelho e preto, mas alguns moradores têm participado de iniciativas para resgatarem algumas dessas, com o auxilio de pesquisadores e de Alto Paraíso.

O plantio do milho também tem início após as primeiras chuvas, que ocorriam tipicamente entre setembro e outubro. Entretanto, nos últimos anos o período chuvoso só tem começado a partir de novembro, atrasando o início de suas atividades produtivas . De quatro a cinco meses após o plantio, ocorre a dobra do milho que permite que no mês de abril ele já esteja seco no campo, mas a colheita só costuma ocorrer entre junho e julho.

Para os moradores do Vão de Alma, a melhor lua para colher o milho e evitar o caruncho, é a lua minguante. A seleção dos grãos que serão utilizados como sementes no ano seguinte já foi explicitada anteriormente (item 4.1.2, pagina 76), mas elas também podem ser adquiridas com vizinhos. As sementes vendidas nos centros urbanos são consideradas de má qualidade: "as [sementes] da cidade não presta" (morador do Vão de Almas). As sementes oriundas da CONAB e distribuídas pela Associação Mãe também não são bem vistas pela comunidade, que prefere manter a sua própria reserva de um ano para ou outro.

$\mathrm{Na}$ comunidade do Engenho II o milho foi predominantemente observado junto ao feijão. Já na comunidade do Vão de Almas, o padrão adotado e a combinação de milho e mandioca, uma vez que nessa localidade não se costuma plantar o feijão comum, só o de 
corda. De forma geral, a produção do milho não é voltada para o comércio dentro do território, e possui caráter unicamente de subsistência. Ele pode ser utilizado como ração para os animais, na produção do fubá ou para o beiju.

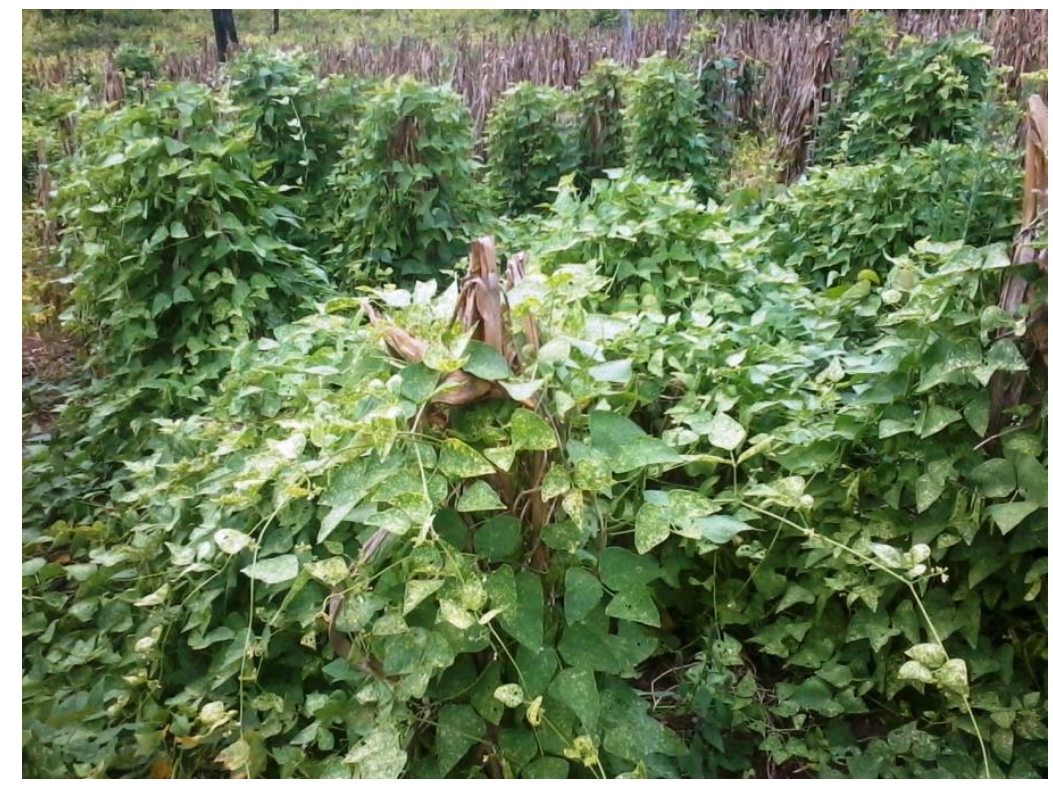

Figura 22 - Feijão associado ao milho (já seco e dobrado), na comunidade do Engenho II (Fonte: Trabalho de campo. Maio de 2014)

\subsubsection{Feijão}

O feijão, de acordo com os moradores da região, não produz bem no solo do Vão de Almas, que é mais arenoso e geologicamente desgastado. Dessa forma, todas as roças com feijão que foram visitadas faziam parte da região do Engenho. As observações ocorreram pouco antes da colheita dessa espécie, o que permitiu a averiguação de quatorze variedades distintas, como o feijão de Corda, Marelão (Amarelão), Feijão 60 dias, Leite, Roxinho, Amarelinho, Momoninho, Manteiga, Fava, Catador, Pequeno, Mucunjá, Fedegoso e o Andu.

Seu plantio é tipicamente associado ao milho, mas pode ser cultivado de forma isolada, sendo assim chamado de "feijão solteiro". A sua produção é considerada menos trabalhosa, e por isso muitas vezes adotada pelos jovens agricultores ou por aqueles que não possuem tempo suficiente durante aquele ano para investir em outras culturas mais intensivas em trabalho (como o arroz), além de não necessitar de vigília durante a maturação e ser de rápido retorno. O feijão é plantado ao longo dos meses de janeiro, fevereiro e março, a depender das chuvas, e é colhido de maio a junho.

As variedades de feijão são plantadas todas juntas, e foi possível observar em uma mesma roça, lado a lado, cinco variedades distintas. Essa dinâmica também foi observada com a cultura do arroz, e o consumo desses produtos agrícolas, em muitos casos, ocorre 
também de forma mista. Esse hábito da comunidade aumenta a diversidade nutricional do alimento "feijão" que chega às mesas, além de suprir o paladar identitário da população, como será tratado mais adiante.

No Engenho, mesmo com boa terra de cultura, e a produção farta de feijão, a quantidade produzida não abastece as famílias por todo o ano. Dessa forma, por períodos de três a seis meses ao ano, é necessário adquirir feijão de outras regiões. Assim sendo, não existe excedente de feijão a ser vendido pelas famílias, uma vez que a escolha dominante é pelo consumo integral desse produto.

Nos meses de escassez de feijão local, as famílias possuem três opções: aceitarem o feijão oferecido na cesta básica distribuída pela Associação mãe, comprar pacotes de feijão industrializado nos mercados das cidades próximas, ou adquirir sacas de feijão de outros produtores de regiões próximas, como os de Alto Paraíso. A primeira opção é a menos aceita pela população, que se queixa constantemente da qualidade do feijão que é oferecido. Esse produto é de tal forma rejeitado que chega a ser, muitas vezes, ofertado como ração para os animais domésticos, mas, aparentemente, nem mesmos esses o apreciam.

A segunda opção, referente a aquisição nos comércios locais extrapola a questão do sabor preferencial, e adentra o aspecto econômico. O feijão vendido nas cidades é caro, que torna pequenas porções acima do poder aquisitivo das famílias. Isso as leva a terceira opção, a de adquirir grandes quantidades de feijão por preços mais acessíveis, junto a outros produtores. Essa alternativa, predominante entre as famílias do Vão de Almas, também é utilizada por moradores do Engenho, mas nessa comunidade é comum a aquisição do feijão "ensacado" vindo do comercio local, que já está presente no vilarejo, em forma de pequenos mercadinhos e mercearias.

[...] se faz um ano que num chove quase nada e dá muito sol, ai nois tem que ir na cidade e comprar arroz e feijão, por que ai não dá pro ano todo. Mas é caro e ruim, num tem o mesmo gosto do daqui. É melhor usar o nosso mesmo (Moradora do Engenho II).

Apesar do Vão de Almas não produzir o feijão convencional, seus moradores plantam o feijão de corda ao longo do ano, mas sem associação com outras espécies, uma vez que ele "se engancha" nas outras plantas e atrapalha o desenvolvimento dessas. Esse tipo de feijão é preferido em sua forma fresca, por isso a estocagem para consumo contínuo não é uma opção muito adotada na região. 


\subsubsection{Arroz}

O arroz é uma cultura que vem ganhando mais espaço na alimentação Kalunga. Apesar de estar junto com as comunidades negras desde as fugas do período da escravidão, a sua relevância dentro da dinâmica nutricional era menor. Um fator que pode estar ligado a esse crescente aumento, é a aquisição de variedades menos dependentes de terrenos alagados e de rápido crescimento, como o arroz "Três meses" e Milharim, adquiridos nas cidades.

Aqui cabem dois comentários em relação a essas observações de campo. O primeiro é referente ao abandono de espécies crioulas em prol das espécies selecionadas. segundo é o abandono de um paladar típico em prol de uma produtividade maior nas colheitas anuais. Ambas as questões estão relacionados, e levam a alterações nutricionais e gastronômicas, além de vulnerabilizarem o grupo às fragilidades inerentes das espécies artificiais criadas em laboratórios, uma vez que geram a redução da variabilidade genética regional. Aqui, como no caso das variedades de mandioca, sugere-se uma investigação mais profunda, auxiliada por projetos voltados para manutenção e resgate de etnovariedades.

O plantio do arroz demanda maior investimento de tempo e mão de obra por parte dos agricultores Kalungas, se comparado com produtos anteriormente citados. Seu plantio iniciase no final de novembro e dura até janeiro, quando os solos já estão úmidos e as chuvas regulares. Após o primeiro mês, é necessário que se retorne as roças para a limpa do terreno, o que se repetirá após mais dois meses. No terceiro mês, após o plantio, é preciso que se quebrem as ramas mais altas da vegetação que se desenvolve entre o arroz. Isso evita a aproximação dos pássaros que predam a plantação. Entre o terceiro e o quarto mês é preciso que se mantenha alguém diariamente nas roças, a fim de vigia-la. Essa atividade é realizada por o grupo familiar, que é auxiliado por instrumentos como o bodoque, o estilingue e as fundas, como já foi citado.

A colheita ocorre entre fevereiro e março. Nessa etapa são envolvidos familiares e vizinhos, que ajudam a "bater e abanar o arroz", só depois disso ele é levado para secar nos quintais das casas e, posteriormente, ensacado. As sacas de arroz podem ser armazenadas nos ranchos, que são construídos junto às roças, ou nas moradias. A prática mais comum é a estocagem nos ranchos, onde o morador busca o produto conforme a necessidade (Figura 23).

A colheita a gente faz um barro lá na roça, fecha tudo direitinho, destelha de palha de arroz mesmo, ou de palha de indaiá, e ai faz uma cama lá e ai bate o arroz. Vai todo mundo. Um vai cortar, o outro vai carregar, o outro vai bater. Depois a gente vai tirar o arroz da banca pra secar, ai já é pra ir pro 
saco. Bana todinho lá na roça e trás cá pra casa. Ai cá em casa a gente vai ter uma lona pra espalhar no solo pra secar (Morador do Vão de Almas).

A cultura desse grão necessita de terras úmidas e com alto teor de matéria orgânica, encontradas próximas aos cursos d'água. Geralmente é o plantio pioneiro após o pousio do solo. A sua lavoura raramente se repete na mesma área, devido à quantidade de espécies "invasoras" que se estabelecem a partir do segundo ano de exposição do solo. Esse mato que cresce junto às culturas, chamado de "imundice", quando fica muito denso, dificulta as atividades agrícolas e pode até inviabilizar o desenvolvimento das variedades delicadas, como o arroz. Afim, de evitar desperdício de mão de obra, os Kalungas investem esforços nos dois primeiros anos, onde o solo está menos suscetível a essas ervas daninhas, inserindo outras culturas a partir dos anos seguintes.

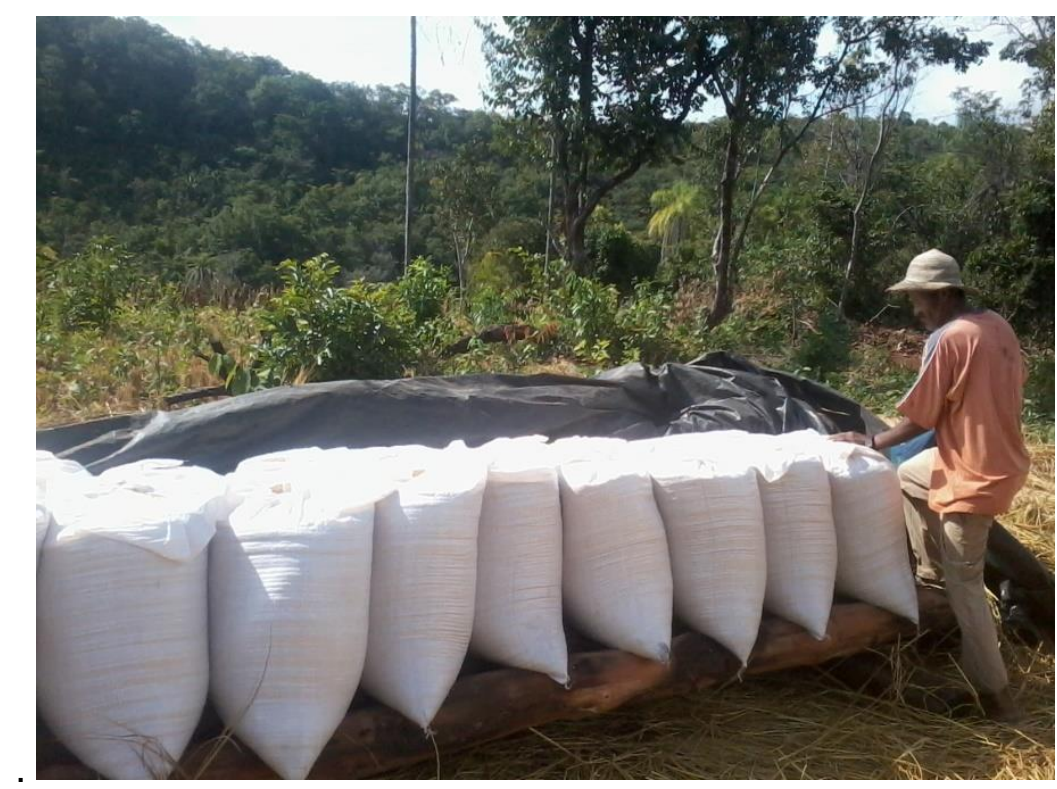

Figura 23 - Sacas de arroz ainda na roça. Engenho II. (Foto: Ludivine Eloy, trabalho de campo. Maio de 2014)

A quantidade média de arroz produzida pelas famílias é suficiente para até três anos de consumo familiar, podendo ainda gerar excedentes que serão vendidos nas cidades próximas. Todavia, essa atividade vem diminuindo gradativamente. Alguns moradores atribuem isso a diminuição das chuvas, mas outros fatores sociais tem ajudado nessa alteração, e serão tratados em outro tópico.

Algum tempo nós vendia, hoje não ta compensando, o povo muito ta falando que o povo é preguiçoso, mas não é preguiça não. É que ta preguiçoso é de trabalhar perdido. Que a chuva não chove (Morador do Vão de Almas).

Faz dezoito anos que eu mudei pra aqui, pra li eu plantei uma roça ali que deu, pequena a roça, deu 52 saco de arroz, deu de comer três anos. Dá ultima vez eu prantei e colhi 10 sacos, dá pra um ano, que eu tava com um 
bucado de filho lá em casa. Dava pra um ano. Hoje eu to comendo comprado (não plantou no ano anterior). Eu preferi comer o meu que eu plantei lá, por que esse arroz que vem de fora ai, além de ele não ter vitamina nenhuma, é tudo plantado com veneno, e o nosso lá é plantado sem veneno. Melhor. Esse ano eu vou plantar (Morador do Vão de Almas).

A troca de serviços nas roças por parte da produção é uma dinâmica que ainda não foi comentada, mas que ocorre não só na cultura do arroz. Essa troca de mão-de-obra por uma porcentagem do que é colhido no campo, sempre foi comum entre membros da família. Entretanto, no Engenho foram entrevistados dois moradores que estavam trabalhando em roças não relacionadas às suas famílias. Aparentemente essa dinâmica ocorre com agricultores de diversas comunidades dentro do território, onde os moradores ofertam sua mão-de-obra, ou por carência de recursos para iniciarem uma nova área de cultura em suas terras, ou por terem perdido as suas produções devido a fatores climáticos desfavoráveis.

Essas famílias, que não estão cultivando nas suas próprias roças, ou que não produzem arroz suficiente, precisam adquiri-lo "ensacado" (industrializado) ao longo da estação seca. A aquisição desse tipo de arroz é cara, e, seu sabor e capacidade nutricional são questionados pelos Kalungas, que também não apreciam o fato dele ser produzido com o auxílio de "venenos" (insumos agrícolas), como observado trecho de entrevista já transcrito acima.

A soca do arroz, atividade realizada para retirar a casaca do grão, já não é realizada manualmente nas localidades onde as máquinas que realizam essa atividade já foram adquiridas. Entretanto, nenhuma delas é de propriedade do governo, ou foi adquirida a partir de projetos institucionais, e por isso os moradores pagam por esse processo. $\mathrm{Na}$ comunidade do Engenho, cinco das seis famílias entrevistadas descascavam o arroz em uma das máquinas presentes no local.

No Vão de Almas a realidade é outra, e o custo do deslocamento até um desses equipamentos encareceria muito os custos da produção, por isso, nessa região, ainda observa-se a soca manual do arroz em todas as famílias visitadas. Entretanto, essa atividade ocorre ao longo do ano, conforme necessidade de uso, mas quando existe a possibilidade, sempre se prefere transportar o arroz até localidades onde exista energia elétrica e máquinas que realizem esse processo.

\subsubsection{Gergelim}

O gergelim é uma planta originária do oriente, mas que está presente nas roças Kalungas desde que eles chegaram à região. Ela é cultivada de forma associada com o arroz, mas o momento do plantio é diferenciado, como se explica abaixo: 
Planta tudo junto misturado, o arroz, o gergelim, a melancia, a abóbora, o quiabo a gente planta tudo junto. O gergelim é assim, depois que a gente planta que o arroz já ta anelado a gente joga o gergelim, se não ele come o arroz. [..] Anelar é querendo perfiar, perfiar é o seguinte, só um grãozinho nasceu um grão, quando vai perfiando ao redor (nascendo outros brotos ao redor) ai que a gente joga o gergelim. Ai você ta olhando de longe ai, e ele já ta tampando a terra, depois de limpar ele você olha de longe e vê que ele já ta tampando a terra. Ai a gente joga o gergelim, por que o gergelim é rápido. Rápido ele cresce, mais que o arroz (Morador do Vão de Almas).

Esse cultivo é preferencialmente plantado no mês de dezembro, mas a época pode variar de acordo com a frequência das chuvas, que determina a época do plantio do arroz, uma vez que um produto está associado ao outro. A colheita é realizada a partir de junho, depois da corta do arroz. O único cuidado especial que se deve ter com essa pequena erva é a expulsão esporádica dos pássaros, após a retirada do arroz, momento em que geralmente as roças ficam "abandonadas".

Após o gergelim ser cortado das roças, ele é colocado em pé, junto à estruturas similares a paredes de palha, para secar ao sol. Só após esse processo ele é batido sobre a lona, e passado pelas quibanas, a fim de separar a casca das sementes, e por fim é ensacado. A produção anual no Vão de Almas é de dois a seis sacos por família, que são vendidos na cidade a dez reais o litro.

Entretanto esse produto é muito apreciado na alimentação Kalunga, seja na forma de paçocas ou como óleos, extraídos artesanalmente pelas mulheres da comunidade. Essa semente, muito rica em gordura, rende em média $50 \%$ do seu peso em óleo, muito mais que a média dos demais produtos utilizados nesse tipo de produção, e por isso é considerado um produto que "rende bem".

O óleo de gergelim é muito apreciado na culinária local, mas a demanda por esse produto nas cidades próximas, e o seu elevado valor de venda, tem feito com que quase todo ele seja comercializado, com valores que variam de trinta a quarenta reais por litro. Contudo a produção é pequena, não ultrapassando mais que quatro litros por ano em nenhuma das famílias entrevistadas. Mesmo assim, ainda são encontradas pequenas garrafinhas de óleo em quase todas as casas Kalungas visitadas.

O gergelim in natura também é muito procurado pelos comerciantes da região, e por isso facilmente vendido nas cidades de Alto Paraíso e de Cavalcante. Os moradores contam que algumas vezes a safra já era negociada antes de ser colhida, mas o não comprimento dos preços acordados, por parte dos compradores, tem levado os produtores a desistir dessa prática. Mesmo sendo um ótimo produto comercial, as famílias costumam guardar 
uma média de oito a dez litros de gergelim para o autoconsumo e para que sirva de semente no ano seguinte.

\subsection{4. Áreas de Cultivo}

As terras de cultura estão distribuídas de forma não homogenia ao longo do território Kalunga, uma vez que apenas 35\% dele estão aptos para atividades agropecuárias. Essa disposição espacial é influenciada pelos tipos de solo, relevo, vegetação e acesso de cada região, mas a questão da regularização fundiária é, sem sombra de dúvida, determinante nesse processo. Essa influência é mais facilmente percebida nas áreas de cultivo da comunidade Engenho II, onde as roças já foram griladas e devolvidas à comunidade.

Nesse povoado, a incerteza relacionada ao direito fundiário, levou vários produtores a interromperem suas atividades produtivas, ou a migrarem para outras áreas mais seguras. Com a devolução das terras, antigas capoeiras estão sendo reativadas, diminuindo a pressão, antes existente, sobre as poucas áreas propícias de roçado.

A região do Engenho II é abundante em terra de cultura, e é conhecido por ser um lugar em que "tudo que planta dá". Mas como já foi debatido anteriormente, essas roças hoje se encontram longe das moradias, causando algumas complicações relacionadas ao transporte e processamento dos produtos, já que estão localizadas em meio as serras do povoado. A pesquisadora Velloso (2007) realizou um levantamento com todas essas áreas, conhecidas como roças, que estavam associadas às famílias moradoras do Engenho, que totalizaram 17 localidades listadas na

Cada uma dessas regiões agrícolas é cultivada por pequenos agrupamentos familiares, geralmente com antepassados em comum. Isso cria um cenário onde irmãos, e seus filhos, produzem lado a lado. Dessa forma, as dezessete localidades se transformam em mais de cinquenta roças efetivas, desconsiderando as capoeiras.

Os nomes dados a essas regiões, outrora foram os nomes das "fazendas" ocupadas pelas famílias quilombolas. Essa dinâmica ainda se apresenta na região do Vão de Almas, onde cada "fazenda" representa uma região geográfica ocupada por moradores aparentados, de forma próxima ou distante. Como explicado na metodologia, a região do Vão perfaz uma grande extensão de áreas, o que limitou a pesquisa a parte oeste, inferir ao rio Paranã e acima do rio Capivara, e na região do Morro da Bucaina. 


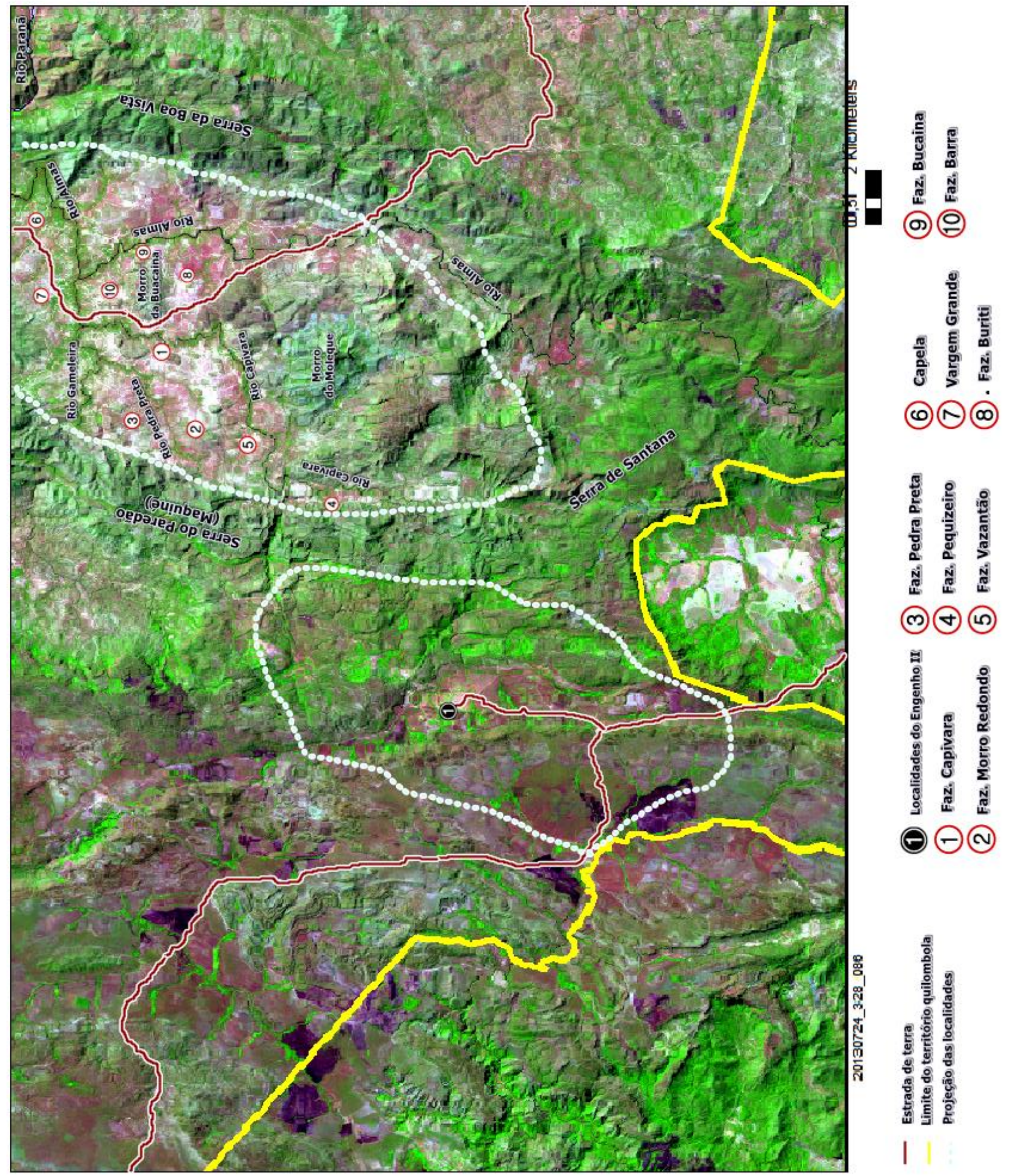

Figura 24 - Projeção da área do Engenho Il e do Vão de Almas, com destaque para suas áreas produtivas. 
Tabela 11 - Roças da comunidade Engenho II. (Fonte: VELLOSO, 2007)

\begin{tabular}{|c|c|}
\hline \multicolumn{2}{|c|}{ Roças da Comunidade Engenho II } \\
\hline Nome das áreas de roça & Famílias produtoras \\
\hline Tamanduá e Chapadinha & José Francisco; Joaquim Francisco; Ubiraci \\
\hline Paciência & Antônio dos Santos \\
\hline Bom Jesus & $\begin{array}{l}\text { Bartolomeu Bueno do Santos; Leonardo dos Santos; } \\
\text { Leocádio; Domingos dos Santos; Gustavo dos Santos; } \\
\text { Manoel Rodrigo }\end{array}$ \\
\hline Chambá & Augusto; Insulina dos Santos ; João dos Santos \\
\hline Choco & $\begin{array}{l}\text { Agripino dos Santos; Valdo; Quincas; Regino; } \\
\text { Genésio, José Neri ; Francisco }\end{array}$ \\
\hline Candarú & Geraldo Francisco; Joaquim; Cirilo; Bernadino Paulino \\
\hline Segredo & Ubirací Francisco Maia; Salomão Francisco Maia \\
\hline Chapadinha & Ubirací Francisco Maia \\
\hline Mato Seco & $\begin{array}{l}\text { Marco Antônio Cezário de Torres; João Neto; } \\
\text { Joaquim; Emivaldo Felipe de Souza }\end{array}$ \\
\hline Palmeira & $\begin{array}{l}\text { Elói Francisco Maia; Elias Francisco Maia; Bernardino } \\
\text { Paulino }\end{array}$ \\
\hline Broccotó & $\begin{array}{l}\text { Emiliano dos Santos Ferreira; José Neri; Elói } \\
\text { Francisco Maia }\end{array}$ \\
\hline Marça & $\begin{array}{l}\text { Roberto; Geraldo; Agripino dos Santos Maia; } \\
\text { Bernardino Paulino }\end{array}$ \\
\hline Marçazinho & Valdo dos Santos; Bernardino Paulino \\
\hline Terra Vermelha & Cazário Paulino da Silva \\
\hline Cercado & Basília Pereira José dos Anjos; Bernardino Paulino \\
\hline Bucaina & $\begin{array}{l}\text { Joaquim Francisco Maia; Simão dos Santos Rosa; } \\
\text { Edmundo Paulino da Silva; Jacinto Paulino da Silva; } \\
\text { Benedito; João dos Santos Rosa; Francisco dos } \\
\text { Santos Rosa; Jenuíno; Ubiraci Francisco Maia }\end{array}$ \\
\hline Fundão & Ranulfo dos Santos Rosa; Jilo Rodrigo da Conceição; \\
\hline
\end{tabular}

As roças da região do Engenho II estão detalhadas na Figura 20, também produzida pela pesquisadora Velloso, no ano de 2007. Já a localização de cada fazenda da região oeste do Vão Almas, assim como seus posicionamentos relativos ao Engenho, podem ser vistas na Figura 24. 
Tabela 12 - Áreas (fazendas) da parcela oeste da região do Vão de Almas, com as respectivas famílias produtoras (Fonte: Trabalho de campo. Jan/Out de 2014).

\begin{tabular}{lll}
\hline \multicolumn{2}{c}{ Roças da Comunidade Vão de Almas (parcela Oeste - 8 localidades) } \\
\hline $\mathbf{N}^{\circ}$ & Nome das áreas (fazendas) & Famílias produtoras \\
\hline 1 & Capivara & Calixto; Zé Mariso; Quelemento; Essílio; Adão; Jesíno; \\
& & Alvino; Maneu; Avilino; João \\
5 & Vazantão & Pulú; Dominga Preta; Joaquim; Decí; Elena; \\
2 & Morro Redondo & Joventino; Zé Merenda; \\
3 & Pedra Preta & Valdomiro; Neco (Santana); Altina; Tonho; Natalino; Osvaldo; \\
& & Ambrósio \\
4 & Pequizeiro & Meria; Ziamar \\
10 & Barra & João; Tuta; Valdeci; Juvenal; Valdinei; Dico; Licono; Jetúlia; \\
& & Oneis \\
8 & Buriti & Tosinho; Janda; Tiana; Dominga; Santo \\
9 & Bucaina & Vanderli; Diana; Doro; Basílio \\
\hline
\end{tabular}

\subsection{PASTOS}

Outra forma de diversificação da alimentação e da renda Kalunga é a criação de gado solto, em pastagens naturais a partir da gestão do fogo nessas áreas. Essa atividade, comum em comunidades camponesas, fornece proteína animal (na forma de carne, leite e derivados), adubação para as hortas, auxílio no transporte de cargas e tração, além de constituir uma forma de poupança para eventos imprevistos (ELOY, CARVALHO e FIGUEIREDO, no prelo 2014).

A raça que trazida pelos quilombolas para a região é o gado Curraleiro, como é conhecida no Goiás e no Tocantins, ou Pé-Duro, como é chamada em algumas regiões do nordeste do país (NEIVA, SERENO e FIORAVANTE, 2011). Ele foi trazido da península ibérica para o Brasil, pelos portugueses, e passou por diversas adaptações decorrente do processo de seleção natural (meio ambiente) e artificial (cultural). Recentemente essa raça havia desaparecido das criações Kalungas, mas em 2006 foi reintroduzido graças ao programa "Estabelecimento e Manutenção de Núcleos de Criação de Gado Curraleiro", desenvolvido pela EMBRAPA, UFG, UnB, SEBRAE e UEG (FIORAVANTE et al., 2008).

As fitofisionomias típicas do Cerrado, como o campo limpo, o campo sujo, o campo rupestre e cerrado ralo, são chamadas "pastagens naturais", e necessitam de um manejo de queima em mosaicos para permitirem o pastoreio do gado ao longo da maior parte do ano, inclusive durante a estação seca. Devido às abordagens adotadas pelas atuais políticas públicas agroambientais relacionadas ao fogo, o discurso da comunidade em relação ao fogo vem se alterando, mas não se sabe se isso realmente reflete ações práticas da população. Essa questão carece de maiores estudos, que acompanhem as atividades 
relacionadas à pecuária na comunidade, a fim de se entender como essas ações governamentais têm impactado sobre as práticas pastoris dessa população.

\subsection{O QUINTAL, A HORTA E O POMAR}

O quintal, a horta e o pomar, são ambientes de cultivo, em pequena escala, de espécies alimentícias como frutas, verduras e legumes, que se distinguem pela finalidade e localização dentro da propriedade familiar. A horta é a dinâmica mais rara, e recentemente adotada da comunidade, consistindo em uma caixa de terra suspensa sobre um giral de madeira, geralmente localizado no quinta das residências principais. Ela está presente em aproximadamente $20 \%$ das casas Kalungas (SEPPIR/Fubra, 2004), mas essa porcentagem tem crescido, principalmente na comunidade Engenho II, após projetos sociais de hortas comunitárias e o Giral do Saber ${ }^{1}$, realizado por pesquisadores da UFG.

Nesse espaço alimentar foram encontradas as seguintes variedades: tomates, cenoura, alface, coentro, beterraba, rabanete, nabo, rúcula, couve, salsa, cebolinha, cebola e alho. Os produtos são mantidos na terra até serem requisitados para algum preparo culinário, dessa forma estão sempre frescos. É perceptível que muitos deles, como a alface, a rúcula e os rabanetes foram recentemente introduzidos, e ainda não fazem parte dos hábitos alimentares da comunidade, mas são constantemente oferecidos aos turistas que procuram refeições no Engenho II.

Nas famílias visitadas no Vão de Almas, essas variedades foram reduzidas a um número menor de espécies, sendo realmente popular nas hortas suspensas só os temperos, como salsa, cebolinha, alho e cebola, e a couve. O espaço nomeado de quintal, que envolve as casas da zona rural Kalunga, foi recentemente objeto de pesquisa de Pereira e Almeida (2011), da UFG.

Nesta pesquisa o quintal Kalunga é definido como um lugar e espaço de saberes, geralmente situado ao fundo das casas, onde se encontram plantas, distribuídas de em padrões semelhantes (plantas maiores ao fundo, e as menores próximas as casas), onde se localiza também a horta. Geralmente este é um espaço administrado pelas mulheres, onde essas reproduzem saberes adquiridos por gerações (PEREIRA e ALMEIDA, 2011).

É nesses espaços que se encontram as ervas medicinais mais utilizadas no dia-a-dia das famílias, assim como algumas variedade alimentícias e utilitárias de uso frequente,

${ }^{1}$ O Giral do Saber é um projeto de extensão da Faculdade de Artes Visuais da UFG que atua dentro da comunidade Kalunga. Ele tem parceria com a Secretaria do Estado de Políticas para Mulheres e Promoção da Igualdade Racial (Semira), Prefeitura Municipal de Cavalcanti e com a AQK. 
como a mandioca doce, a cana, milho, jiló, a cabaça, o timbó, o algodão e as pimentas entre outras (Tabela 13). Além disso, o quintal kalunga muitas vezes abriga pequenos pomares, assim como aqueles observados junto às roças.

O quintal Kalunga é mantido e administrado por suas mulheres, que o criam logo após o seus casamentos, pois esses tinham papel fundamental na saúde e na alimentação de suas famílias. Hoje, com os alimentos e medicamentos industrializados, é comum escutar reclamações das matriarcas a respeito da falta de interesse das mais novas em aprenderem sobre os conhecimentos tradicionais da comunidade. Entretanto, por mais reduzido que ele possa apresentar-se, o quintal foi verificado em todas as famílias visitadas, e sempre contado com representantes de espécies vegetais associadas as três categorias; alimentícias, medicinais e de uso tecnológico (confecção de utensílios e outros).

Tabela 13 - Plantas identificadas nos quintais Kalungas. (Fonte: PEREIRA e ALMEIDA, 2011)

\begin{tabular}{|c|c|c|c|c|}
\hline \multicolumn{2}{|c|}{ Medicinais } & \multicolumn{2}{|c|}{ Alimentícios } & \multirow{2}{*}{$\begin{array}{l}\text { Utensílios/outros } \\
\text { Cabaça }\end{array}$} \\
\hline Mastruz & Algodão & Mandioca & Banana & \\
\hline Fedegoso & Cidreira & Manga & Abóbora & Jacaré* \\
\hline Vassourinha & Velame & Cana & Batata & São Gonçalo* \\
\hline Ventre Livre & Babosa & Pimenta & Mutamba & Pinhão Roxo \\
\hline Capim Reis & Dipirona & Cagaita* & Tomate & Burere \\
\hline Capim de Cheiro & Vic & Abacaxi & Mostarda & Timbó \\
\hline Alfavaca de Horta & Folha de Cravo & Feijão Andu & Lima & Tinguí \\
\hline Alfavaca de Gado & Manjericão & Caju* & Laranja & Pão-terra* \\
\hline Carrapicho & Folha Santa & Pequi* & Quiabo & Álcool Branco* \\
\hline Gota do Zeca & Pimenta Jaborandi & Mangaba* & Feijão de Corda & Polista \\
\hline Hortelã Grosso & Arnica & Vinagreira & Jambo & \\
\hline Cabaça & Xioio & Coentro & Jamerão & \\
\hline Capim Santo & Jervão & Tamarindo & Adestragem & \\
\hline Chapada* & Boldinho & Maracujá & & \\
\hline Geivão* & Canafiche & Siriguela & & \\
\hline Caiba* & Unha-de-gato* & Goiaba & & \\
\hline Sucupira* & Poejo & Romã & & \\
\hline Sambaiba* & Astimije & Acerola & & \\
\hline Mamona & & Jiló & & \\
\hline
\end{tabular}

Os pomares da comunidade podem ser encontrados junto às casas, ou junto às roças. Quando localizados próximos às casas integram o, já mencionado, quintal (Figura 25). Ele é composto principalmente por espécies exóticas ao cerrado, como a mangueiras, amoreiras, laranjeiras, jaqueiras e limoeiros, mas nele também se observam as espécies alimentícias 
nativas mais apreciadas, como o pequi, a mangaba, o cajuí, a cagaita e bacupari. Algumas dessas espécies nativas são plantadas, mas a maioria brota naturalmente a partir dos restos de fruto jogados no entorno das casas.

$\mathrm{Na}$ comunidade do Engenho II, onde as roças são distantes das casas, os pomares também estão presentes junto as áreas de plantio, com uma diversidade tão grande quanto a encontrada junto as casas, a exceção das plantas nativas, que não são propositalmente cultivadas nesses locais, mas são intencionalmente selecionadas, quando da feitura das queimadas. Esse é o caso das palmeiras, como o Buriti e o coco Xodô, que são poupados durante a abertura das roças e posteriormente se beneficiam com a redução da vegetação circundante, havendo um significativo acréscimo no número de novos indivíduos (Figura 25).
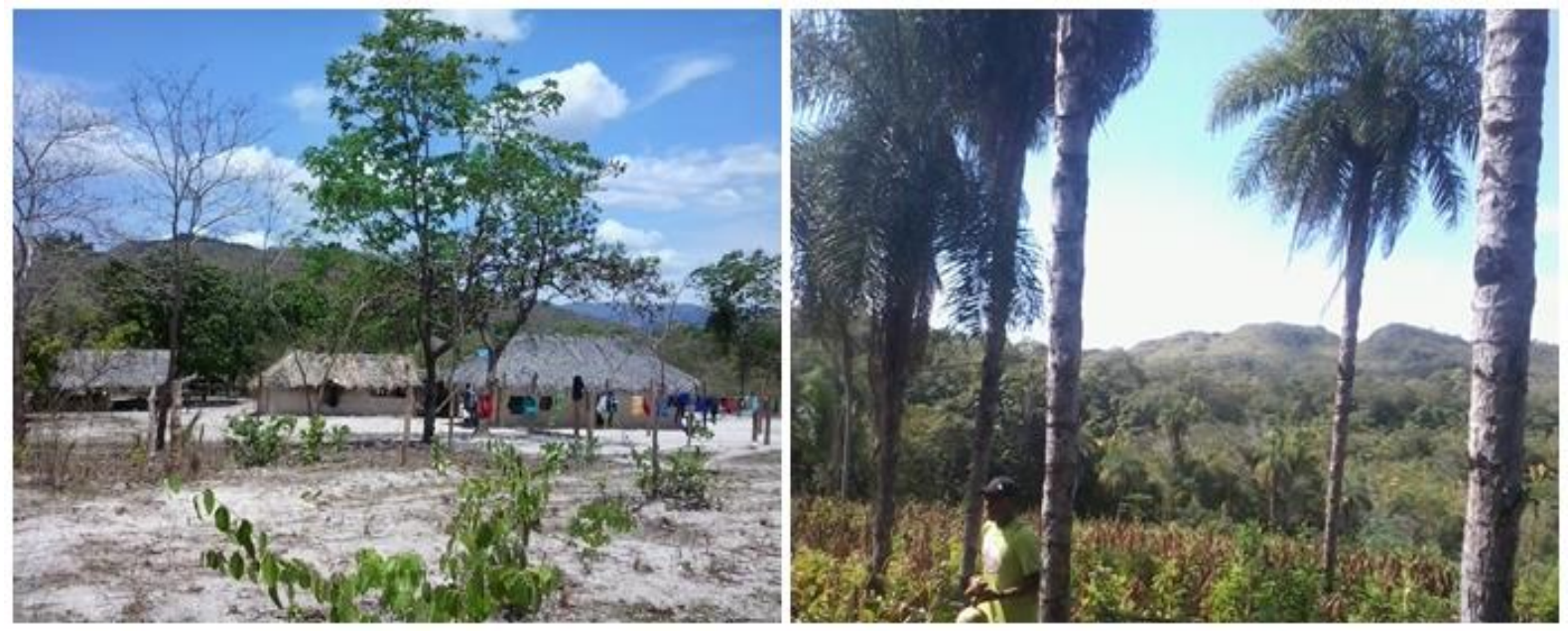

Figura 25 -(Esq) Casa Kalunga do Vão de Almas. Ao fundo é possível ver o pequeno pomar que se estabelece a partir das árvores nativas e exóticas que são cultivadas.(Dir) Roça do Engenho, onde é possível ver as palmeiras selecionadas (Fonte: Trabalho de campo. Jan/Out de 2014).

Os pomares estão constantemente povoados pelas crianças, que também são suas grandes beneficiadas, uma vez que realizam todas as "entre refeições" (ou lanches) de forma autônoma, em meio aos pomares e quintais. Ao contrário das cozinhas, espaço rigidamente controlado pelas mães Kalungas, os pomares e matas oferecem fartura de frutas sem supervisão régia, que faz a alegria das crianças, principalmente durante a estação chuvosa na qual abundam as frutas nativas e exóticas. Se pode-se dizer que as cozinhas são espaços controlado pelas mulheres, talvez possamos dizer que os pomares são o domínio das crianças quilombolas.

Esses três tipos de espaço são essenciais para a segurança alimentar Kalunga, uma vez que complementam aquilo que as áreas de roça não podem fornecer, como as frutas, os legumes e as folhagens. $\mathrm{Na}$ realidade, mesmo nas cidades próximas, essas variedades dificilmente são encontradas, devido à péssima qualidade das estradas, que encarecem o 
preço dos fretes e desmotivam os comerciantes locais. Ou seja, é indispensável que haja esses espaços alimentares junto às casas ou as roças, uma vez que não é possível obter essas variedades nem quando se pode pagar por elas.

\subsection{O EXTRATIVISMO}

O extrativismo é um termo geralmente utilizado para designar uma atividade econômica baseada na coleta ou extração de recursos naturais, diretamente do ambiente. Aqui empregar-se-á ele de forma mais ampla, sem ligação direta com a comercialização de produtos, uma vez que são poucos os produtos dessa atividade cuja finalidade é monetária, dentro do território.

Assim como já foi demonstrado para alguns cultivos, a economia Kalunga possui o caráter peculiar de, manter forte parcela de suas atividades fora da esfera monetária (UNGARELLI, 2009; BAIOCCHI, 1999), Da mesma forma que a maior parte dos produtos das roças não está destinada à transações financeiras, os produtos oriundos do extrativismos também visam outras finalidades. Entretanto, tem crescido o número de moradores que percebe na comercialização de seus produtos uma nova alternativa de renda para as famílias.

A relação do povo Kalunga com a biodiversidade cerratence sempre foi fundamental para a subsistência desse grupo, que conhece sua dependência e por isso respeita seu ambiente, compreendendo os ciclos naturais e limites impostos por eles. Dessa forma, o conhecimento associado a esse bioma é intrínseco à cultura aqui estudada, e permeia todas as informações coletadas, mas abordaremos aqui neste tópico, especificamente os conhecimentos relacionados às plantas alimentícias do cerrado, deixando as variedades medicinais e destinadas a confecção de utensílios fora do escopo desta pesquisa. $O$ extrativismo vegetal associado a fins medicinais foi amplamente abordado no trabalho da pesquisadora Massarotto (2009) da Universidade de Brasília.

Tendo dito isso, abordar-se-á nos próximos parágrafos as principais espécies nativas extraídas do cerrado e sua destinação dentro do sistema alimentar dessa comunidade. As destinações não alimentares serão brevemente citadas, mas não aprofundadas, como no caso das tinturas, artesanatos e medicamentos.

O Cerrado é o segundo bioma mais antigo do Brasil, e guarda $5 \%$ da fauna e da flora mundial e $30 \%$ da biodiversidade brasileira dentro das suas matas, campo e cerradões. Estima-se que ele possua mais de 10.000 espécies vegetais, valiosas em si, mas também importantes pelas suas utilizações. Algumas dessas espécies, destinadas apenas para 
alimentação, foram levantadas por Ungarelli (2009), e conferem e enriquecem a lista já levantada ao longo das trilhas guiadas no período da pesquisa de campo. São elas:

Tabela 14 - Listagem das espécies alimentícias extraídas do cerrado, na região do Engenho II e de Vão de Almas(conferidas em campo) (Fonte: UNGARELLI, 2009)

\begin{tabular}{ll}
\hline 1. Jatobá & 2. Curriola \\
3. Pequi & 4. Cajuí \\
5. Gueroba Verdadeira & 6. Coco Indaia (Pindoba) \\
7. Baru & 8. Coco Buriti \\
9. Cagaita & 10. Coco Licuri \\
11. Mangaba & 12. Coco Xodó (Macaúba) \\
13. Baquarí & 14. Coco Catulé \\
15. Puxa-puxa & 16. Coco Araçá \\
\hline 17. Mama-cadela & 18. Gueroba \\
\hline 19. Muricí & 20. Gabiroba \\
\hline
\end{tabular}

Nesta lista foram omitidas as subespécies, que só no caso dos palmitos, chegam a quatro. Sete dessas espécies são frutas, destinadas para o consumo in natura, confecção de polpas, geleias e doces, como é o caso da cagaita, mangaba, mama-cadela, muricí, cajuí, puxa-puxa e gabiroba (tipo de goiaba rasteira). Quando a comunidade possui energia elétrica, como é o caso do Engenho II, as famílias podem congelar as frutas in natura, ou as suas polpas. O uso mais comum é para sucos, mas algumas famílias fazem doces, como é o caso do cajuí, que pode virar, geleia, compota ou doce cristalizado, além de polpa para suco.

A mangaba e a cagaita são citadas predominantemente para o consumo in natura e na forma de sucos. Já a mama-cadela, o puxa-puxa, a gabiroba e o baquari são frutas preferencialmente consumidas in natura. No início das chuvas, época de abundância dessas espécies no cerrado, é comum encontrar famílias que juntam pequenas quantidades de frutas e levam para as cidades, onde vendem de porta em porta ou para amigos e conhecidos. Esse período dura cerca de um mês, e as vendas subsequentes são unicamente de polpas congeladas. 
Os palmitos, conhecidos popularmente como gueroba, gueiroba ou gaririba, estão divididos nas variedades Verdadeiro, Catulé, Falsa e Palmito Soldado. Eles são considerados iguarias e são retirados em ocasiões significativas, como visita de "gente da cidade", festas e aniversários.

Os "cocos", ou palmeiras, são espécies muito respeitadas entre as populações quilombolas. Eles oferecerem uma gama grande de produtos e por isso são poupados, mesmo quando se limpam os terrenos das roças. Alguns deles são aproveitados de tal modo que se costuma dizer que "se aproveita tudo", como no caso do Buriti. As variedades Indaiá (Pindoba) e Macaúba (Xodó) são usadas não só para a confecção de óleos, mas também para a produção do leite, extração da castanha e raspagem do dendê (polpa). Babaçu também pode ser usado para a extração do óleo de coco, muito apreciado na cultura Kalunga, tanto para a culinária quanto para fins medicinais e estéticos.

O jatobá é uma espécie emblemática do cerrado, e vem ganhando espaço nos espaços gastronômicos das cidades, mas o seu sabor e valor nutritivo veem sendo apreciado pela comunidade quilombola há alguns séculos. Sua polpa, de textura farinácea e odor marcante, é ressecada ao sol e pilada para a criação de uma farinha, extremamente nutritiva, aplicada na confecção de bolos e vitaminas. Sua casca é reaproveitada como carvão, e também pode ser utilizada como remédio, quando transformada em pó.

Por último falar-se-á do pequi, fruto símbolo do cerrado goiano, sendo nacionalmente conhecido pelos seus usos culinários. A sua popularidade regional só é igualada pela grande gama de produtos usados localmente. Do pequi são preparadas a polpa desidratada, o caroço descascado, as conservas, a farinha, o óleo e o doce, além de vários pratos. Uma das vantagens que essa fruta apresenta para as famílias que a coleta, é que pode ser descascada onde estiver e levada para casa já na etapa de caroço. Os sacos de pequi sem casca são vendidos in natura, mas também congelados (quando existe energia) para serem vendidos após o período de frutificação.

A próxima etapa do seu processamento é a retirada da polpa, para ser estocada ou vendida desidratada, ou em forma de farinha. Para isso os frutos (já sem casca) são fervidos com água e sal em grandes panelas no quintal das casas. São escorridos e resfriados, após o que são delicadamente raspados com o auxílio de uma colher e colocados sobre o giral ${ }^{2}$, no sol, para secarem (Figura 26).

\footnotetext{
${ }^{2}$ Girau ou Jirau é uma espécie de prateleira alta construída com varas sobre esteios fixados no chão. Serve para estender roupas, guardar caixas, panelas e alimentos. Também é utilizado para secar alimentos ao sol.
} 
O que sobra do pequi, ainda pode ser utilizado para a produção de óleo. Para isso, os caroços sem polpa, são colocados em água fervente para amolecerem, e depois são esmagados, nesse mesmo recipiente, com o auxilio de garrafas de vidro ${ }^{3}$. Voltam ao fogo, onde começam a soltar a sua gordura característica, que é coletada com o auxílio de colheres, e separada em outro vasilhame. Esse processo será repetido após se adicionar mais agua à mistura já reservada, que volta ao fogo, separando-se, assim, o óleo da água. Da borra, que sobra após a retirada do óleo, é produzido o sabão. O litro do óleo é vendido em média a cinquenta reais e a polpa desidratada a vinte e cinco reais o litro
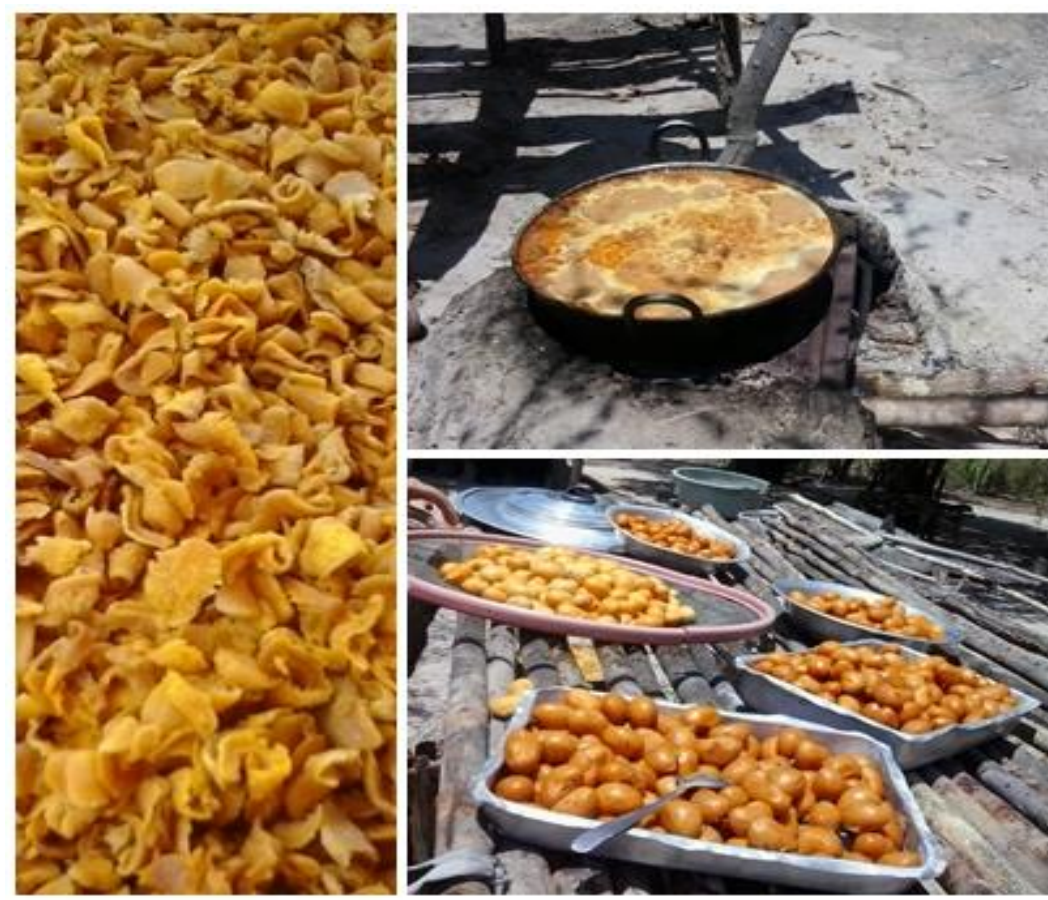

Figura 26 - Pequi em diversos estados de processamento. Vão de Almas, quilombo Kalunga (Fonte: Trabalho de campo. Outubro de 2014).

\subsection{A COZINHA E O PALADAR IDENTITÁRIO}

A alimentação humana extrapola a esfera biológica e adentra o campo social e cultural das populações. Por conta disso,

[...] comida não é apenas uma substância alimentar, mas também um modo, um estilo e um jeito de alimentar-se. $E$ o jeito de comer define, não só aquilo que é ingerido, como também aquele que o ingere. (DA MATTA, 1986, p. 56)

\footnotetext{
${ }^{3}$ As garrafas de vidro são utilizadas como bastões que auxiliam no momento de se esmagar os caroços amolecidos do pequi. Funcionam como pilões ou bastões que ajudam a imprimir força ao processo.
} 
Pensando a partir desse ponto Maciel (2004) propõe que se fale em "cozinhas" como formações culturais estabelecidas e codificadas, que se inserem dentro de um sistema alimentar. Esse sistema alimentar estaria representado por um conjunto de elementos, produtos, técnicas, hábitos e comportamentos relativos ao ato de se alimentar, onde a culinária (o modo de se fazer o alimento) seria mais um. Entretanto, essas maneiras não se limitariam às técnicas, mas englobaria também os significados atribuídos aos alimentos e ao ato de se alimentar.

Até o momento, o presente trabalho tentou mapear esse conjunto de produtos, técnicas e hábitos a fim de criar um perfil do sistema alimentar Kalunga, mas sem tratar das questões simbólicas associadas à alimentação não será possível se falar em "cozinha Kalunga" como um conjunto de significados representativos dessa cultura. Por conta disso, os próximos subtópicos envolveram dados, percepções e relatos no intento de se aproximar de uma descrição mais densa da cozinha desse povo singular.

Da mesma forma que a cultura de um povo passa por constantes transformações e ressignificações, as cozinhas também estão sujeitas a esses processos de continua recriação, por isso nenhum inventário dos alimentos produzidos, por mais detalhado que seja, pode substituir a rede de significados inerente a esses produtos. Transpõem-se as palavras de Brillat-Savarin "Diz-me o que comes e eu te direi quem és", para se chegar na afirmação de Sophie Bessis de que " Diz-me o que comes e te direi qual Deus adoras, sob qual latitude vives, de qual cultura nasceste e em qual grupo social te incluis" (apud MACIEL, 2004; p.27).

Assim, as dinâmicas típicas relacionadas ao sustento da comunidade, influenciaram, ao longo dos anos, os seus hábitos alimentares, criando um paladar identitário, que remete os moradores da comunidade às variedades e comidas consideradas boas. Revela-se ai, uma conexão entre o saber e o sabor (UNGARELLI, 2009), que distingue essa comunidade das outras, ao mesmo tempo em que une seus integrantes. Um dos espaços de convivência destinados ao estabelecimento dessas conexões é a cozinha (estrutura física).

Essa área destinada ao preparo dos alimentos nas casas Kalungas, era originalmente externa à moradia principal. O cômodo à parte estava sempre equipado de um fogão a lenha, pequenas prateleiras e alguns bancos de tronco corrido ou escavados na parede de adobe das casas. Essa disposição também tornava a cozinha mais iluminada, além de impedir que a fumaça do fogão adentrasse nas outras partes da casa. Ainda hoje, nas comunidades mais afastadas, ou sem energia, como a região do Vão de Almas, a construção das casas ainda segue essa mesma dinâmica. 
Entretanto, a cozinha, espaço físico, tem passado por alterações resultantes das novas tecnológicas que hoje chegam até o território, mas que até trinta anos atrás eram completamente distantes da realidade Kalunga. A primeira dessas mudanças está relacionada com a chegada da energia elétrica a algumas localidades, nas quais os moradores podem adquirir eletrodomésticos, como geladeira. A simples presença da lâmpada dentro das casas já torna possível visualizar, de forma satisfatória, os alimentos durante seu cozimento.

A segunda inovação que modificou a estrutura da cozinha Kalunga é o fogão a gás. Esse equipamento, que independe de eletricidade, desassociou o preparo dos alimentos da lenha e da fumaça, o que permitiu uma aproximação da cozinha com os outros cômodos da casa. A combinação dessas duas inovações tecnológicas, junto com a água encanada de algumas localidades, permitiu a cozinha kalunga instalar-se dentro das moradias. Hoje os tipos de cozinha observados são diversos, mas seguem certos padrões conforme a localidade observada.

No engenho II, as cozinhas são dominantemente localizadas dentro das moradias principais, mas nem sempre possuem pias e fogão a gás. Essa inovação, por mais acessível que seja, não conquistou todas as famílias da região, onde $59,1 \%$ dos domicílios possuem fogão a lenha contra 40,9\% com fogão à gás. Embora muitas casas possuam e utilizem ambos os modelos energéticos de preparo, o fogão a lenha ainda é preferido, pois, segundo a comunidade, torna o alimento mais saboroso (ECHEVERRY, 2014).

No Vão de Almas as cozinhas permanecem majoritariamente externas às casas, com fogão a lenha presente em todas as moradias visitadas. Três das cinco famílias entrevistadas possuíam o fogão a gás dentro de suas casas, mas não faziam uso do mesmo, e algumas vezes nem sabiam ligá-lo. Ao redor desse espaço, dominado pela mulher Kalunga, são observados girais, onde panelas e ingredientes ficam expostos à espera de uso.

O chão da cozinha, seja ela interna ou externa, também é um espaço destinado à permanência das crianças pequenas, que devem ficar sempre a vistas de suas mães, enquanto preparam as refeições. A cozinha também está sempre rodeada pelo quintal, que fornece matéria prima fresca durante os preparos. Caso algum ingrediente se encontre distante, as crianças mais velhas são solicitadas a ajudarem:

Se precisa busca um ovo, um tomate. Ou pega uma lenha no monte. Se ta na escola ta na escola, mas na casa nós tem necessitado de ajuda. Numas vezes é fruta que cata, noutras é tempero. Ai traz na hora, ajuda nós, ajuda a família e aprende um tiquim, se quiser. Se quiser aprender aprende. (Moradora do Vão de Almas) 
Até os 12 anos, os meninos e meninas ajudam nas atividades domésticas de forma bem parecida; buscam água, separam o arroz, varrem o terreiro, ascendem o fogo, cuidam dos irmãos menores. Contudo, existe uma exigência maior das meninas, que aos seis anos de idade, muitas vezes já sabem realizar atividades domésticas com qualidade de um adulto (GODINHO, 2008).

A cozinha Kalunga é comandada por mulheres, que fazem desse espaço o coração das suas casas. É nele que se recebem as visitas, se conversa sobre o dia, ou se realiza uma reunião. Os homens realizam atividades nesse território apenas quando solicitados, como transportar panelas pesadas, descascar alimentos, bater algum ingrediente no pilão e mexer panelas grandes demais. Entretanto, os homens sempre estão presentes no ambiente das cozinhas, mas quase como convidados, que devem pedir permissão antes de tocarem em algo.

O papel da mulher dentro da sociedade kalunga foi tema do trabalho da pesquisadora Godinho, que, no ano de 2008, buscou entender as questões de gênero que permeavam a vida do quilombo. Deste trabalho pode-se inferir que as principais funções da mulher, ao longo do dia, dizem respeito a cuidar da casa e dos filhos, transportar a água até a moradia, cuidar das roupas e elaborar as refeições familiares. Fora de casa, a mulher ainda exerce importante papel durante a época do plantio, dividindo o trabalho nas roças com o marido e os filhos.

A mulher é a guardiã da "cozinha Kalunga", detentora dos saberes associados no preparo dos alimentos. Ela é a responsável por transformar o alimento em comida, em transformar uma longa lista de ingredientes em um sabor típico. É ela que prepara o óleo, que limpa a galinha, que rala a mandioca, pila a paçoca, prepara o café, ascende o fogo e colhe os frutos. Por conta disso, as informações relatadas aqui são, predominantemente, oriundos das mulheres da comunidade, que enquanto preparavam o almoço na beira do fogão à lenha, também respondiam a perguntas, aparentemente triviais do seu dia-a-dia, como "o que é uma mentirinha kalunga? Como se prepara ela?", "o que se come em dia de festa?", "como se tira a polpa do pequi?" e "o que vocês comem pela manhã?".

Dessa forma foi possível criar um perfil dos principais itens culinários da cultura Kalunga, que serão apresentados e discutidos abaixo. Quando se revelarem grandes diferenças ou contrastes entre as duas comunidades, os mesmos serão detalhados no corpo do texto, caso contrário, as informações fazem referência aos grupos familiares de ambas as localidades. 
As refeições, nas casas com cozinha externa, acontecem sempre à beira do fogão de lenha, que tanto fornece alimento quanto espanta o frio da madrugada. Nas casas com cozinhas embutidas, as refeições podem ser feitas no cômodo de entrada (sala) ou também junto ao fogão. A primeira refeição do dia é servida cedo, às vezes tão cedo que é apenas substituída por um copo de café. Ela costuma ser leve e acompanhada de café ou chá, composta apenas de um "prato", seja ele o cuscuz, a tapioca ou a mentirinha ${ }^{4}$. Os principais alimentos ingeridos no café da manhã estão listados na

Tabela 15, mas também são os mesmos comumente ingeridos entre as refeições, em forma de lanche, juntamente com as frutas da estação.

Tabela 15 - Alimentos consumidos pela manhã na comunidade Kalunga (Fonte: Trabalho de campo. Jan/Out de 2014).

\begin{tabular}{l}
\hline \multicolumn{1}{c}{ Alimentação Matinal Kalunga } \\
\hline Café ou chá (adoçado) \\
Mentirinha \\
Enroladinho de tapioca (assado) \\
Bijú \\
Cuscuz \\
Mingau de milho (fubá) \\
Paçoca de gergelim \\
Paçoca de coco \\
Rosca de fubá \\
\hline
\end{tabular}

O Almoço é a principal refeição do dia. Seus pratos, característicos da culinária sertaneja e goiana, são, na maioria dos casos, de fácil e rápido preparo, baseados na dupla "feijão com arroz", tão popular ao longo do território nacional. Os principais ingredientes são o arroz, o feijão, a abóbora, o quiabo, o maxixe, jiló e a mandioca (Tabela 16). Entretanto, alguns produtos industrializados vêm ganhando força dentro dessa refeição, como é o caso do macarrão e o do óleo de soja, substituto barato e prático da banha e dos óleos artesanais.

Principalmente durante a época da seca, onde os quintais recebem menos atenção devido à falta de água de fácil acesso (chega apenas a partir de baldes e latas carregadas na cabeça), alguns vegetais são adquiridos nas compras feitas na cidade, como é o caso da

\footnotetext{
${ }^{4}$ Biscoito frito a base de tapioca, ovo, sal e açúcar. É preparado tipicamente no fogão a lenha em forma de espiral ou de bolinhas. Enquanto são servidos ou preparados é comum que se brinque dizendo "Já mentiu hoje, cumadi?".
} 
cenoura, da beterraba e da batatinha. As carnes bovinas possuem procedências diversas, podendo ser adquiridas nos açougues das cidades, nos açougues improvisados que se estabelecem durante as festividades, com vizinhos e parentes ou a partir do abate de algum dos próprios animais. Entretanto, faz parte do paladar local, uma preferência pela carne seca.

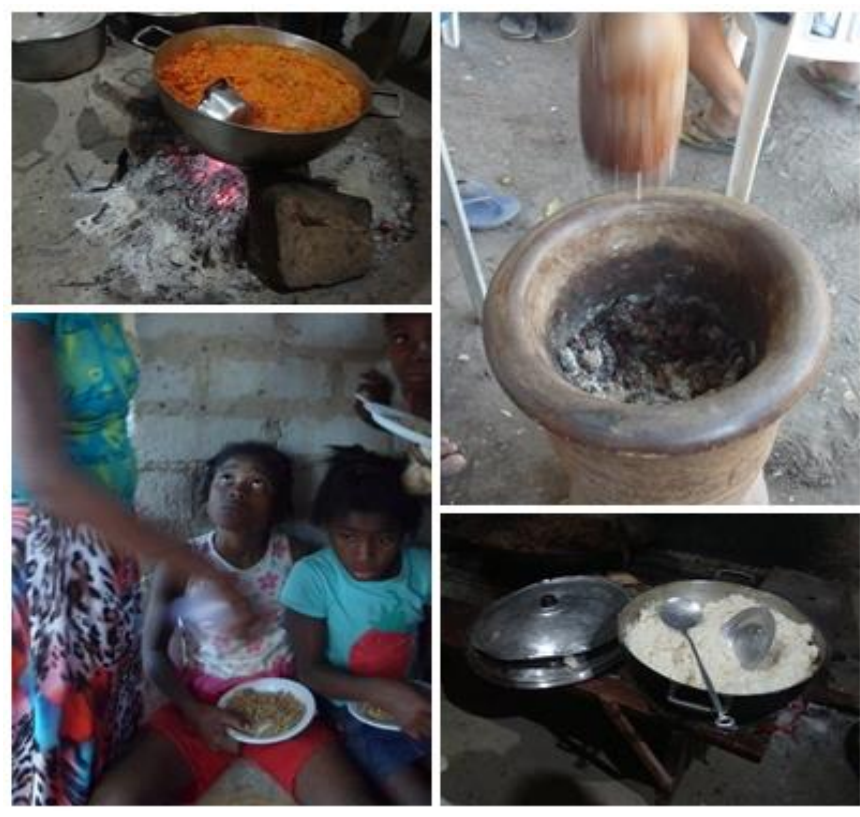

Figura 27 - Comida Kalunga e atividades relacionadas (panela de quibebe de abóbora; paçoca de carne sendo socada no pilão; crianças comendo paçoca; panela de arroz).

A carne de frango é adquirida a partir da criação doméstica desses animais, que ciscam soltos pelos quintais das casas. O frango de granja, vendido congelado nos centros urbanos não é apreciado na comunidade, que evita compra-los. Os ovos consumidos na comunidades também provem das aves que a família possui. Contudo, é comum que tanto o frango quanto os ovos que são oferecidos aos turistas nas refeições encomendadas no povoado do engenho II sejam oriundos dos mercados de Cavalcante, uma vez que a demanda é grande demais para ser suprida por produtos locais.

O peixe, consumido fresco ou seco, é uma comida muito apreciada nas comunidades do Vão de Almas. Nessas localidades existe o hábito recorrente da pesca, em decorrência dos grandes rios que banham a área. Essa preferência, desenvolvida pela abundância local do produto, leva os moradores a, também, adquirirem peixe das compras feitas nos centros urbanos (quando a pesca não é farta).

O jantar tradicional Kalunga é uma repetição do almoço, tanto em quantidade quando nas variedades ofertadas. Algumas vezes, ainda se realiza uma refeição tardia, pós jantar, muito similar ao café da manhã, mas em menor quantidade. 
Tabela 16 - Principais ingredientes do almoço e do jantar nas comunidades Kalungas (Fonte: Trabalho de campo. Jan/Out de 2014).

\begin{tabular}{|c|c|c|c|}
\hline \multicolumn{4}{|c|}{ Almoço/Janta Kalunga } \\
\hline Ingredientes & Carnes & Gorduras & Bebidas \\
\hline Arroz $^{\circ}$ & Peixe fresco ${ }^{\circ}$ & Óleo de Coco & Suco de tamarindo \\
\hline Feijão $^{\circ}$ & Peixe seco & Óleo de Pequi & Suco de manga \\
\hline Abóbora & Carne Seca ${ }^{\circ}$ & Óleo de Gergelim & Suco de mangaba \\
\hline Quiabo & Galinha caipira & Óleo de soja* & Suco de cagaita \\
\hline Maxixe & Carne bovina ${ }^{\circ}$ & Banha de porco ${ }^{\circ}$ & Refrigerante* \\
\hline \multicolumn{4}{|l|}{ Gariroba } \\
\hline \multicolumn{4}{|l|}{ Macarrão* } \\
\hline \multicolumn{4}{|l|}{ Berinjela } \\
\hline \multicolumn{4}{|l|}{ Batatinha* } \\
\hline \multicolumn{4}{|l|}{ Beterraba* } \\
\hline \multicolumn{4}{|l|}{ Cenoura* } \\
\hline \multicolumn{4}{|l|}{ Mandioca } \\
\hline \multicolumn{4}{|c|}{ Farinha de Mandioca } \\
\hline \multicolumn{4}{|l|}{ Pequi } \\
\hline *in & & & idide \\
\hline
\end{tabular}

A comida Kalunga possui um tempero marcante que é fornecido, principalmente, por ingredientes como alho, cebola, açafrão (cúrcuma), cheiro verde e pimenta (Tabela 17). Com exceção do sal, todos os outros condimentos são produzidos na própria comunidade, podendo ser esporadicamente adquiridos na cidade, durante a estação da seca.

Tabela 17 - Temperos típicos da culinária Kalunga (Fonte: Trabalho de campo. Jan/Out de 2014).

\begin{tabular}{l}
\hline Temperos Típicos da Culinária Kalunga \\
\hline Alfavaca \\
Alho \\
Pimenta \\
Açafrão (cúrcuma) \\
Cebolinha \\
Cheiro verde \\
Cebola \\
Sal \\
\hline
\end{tabular}

Apesar de a gastronomia Kalunga ser predominantemente composta de pratos simples e comuns ao paladar nacional, como o arroz e o feijão, existem alguns preparos que 
marcam o paladar desse grupo, funcionando como identificadores frente a outros grupos culturais da região. Alguns desses pratos "símbolos" estão listados na Tabela 18, assim como uma breve explicação dos seus ingredientes e preparos.

Tabela 18 - Pratos típicos da culinária Kalunga (Fonte: Trabalho de campo. Jan/Out de 2014).

\section{Pratos da Cozinha Kalunga}

\begin{tabular}{|c|c|}
\hline Prato & O que é? \\
\hline Banqueto & $\begin{array}{l}\text { Carne cozida, durante todo um dia, temperada } \\
\text { com sal, pimenta, óleo, cebola. Caso a festa seja } \\
\text { grande, pode-se adicionar farinha de mandioca } \\
\text { junto a carne. }\end{array}$ \\
\hline Quibebe de Mandioca & $\begin{array}{l}\text { Mandioca cozida até o ponto de desmanchar. } \\
\text { Pode ser preparada com carne ou sem. }\end{array}$ \\
\hline Quibebe de Inhame & $\begin{array}{l}\text { Inhame cozido até o ponto de desmanchar. Pode } \\
\text { ser preparado com carne ou sem. }\end{array}$ \\
\hline Galinha caipira & Galinha caipira cozida no molho de açafrão. \\
\hline Arroz com Pequi & Arroz com caroço de pequi cozidos juntos. \\
\hline Peixe Frito (VA) & $\begin{array}{l}\text { Peixes de pequeno porte, cozidos inteiros e } \\
\text { picados na gordura, até atingir ficar crocante. }\end{array}$ \\
\hline Peixe ao Molho (VA) & Postas de peixe cozidas no molho. \\
\hline Paçoca de Carne Seca & $\begin{array}{l}\text { Carne seca e farinha de mandioca socadas no } \\
\text { pilão. }\end{array}$ \\
\hline \multicolumn{2}{|l|}{ Banana Frita } \\
\hline Feijoada & $\begin{array}{l}\text { Feijão ao molho preparada com pedaços de } \\
\text { legumes (e as vezes de carne) dentro. }\end{array}$ \\
\hline Arroz Muncuza & $\begin{array}{l}\text { Arroz, feijão e carne cozidos juntos em uma } \\
\text { mesma panela. }\end{array}$ \\
\hline Arroz Sirigado & $\begin{array}{l}\text { Arroz, feijão e abóbora cozidos juntos em uma } \\
\text { mesma panela. }\end{array}$ \\
\hline Pirão & $\begin{array}{l}\text { Farinha de mandioca cozida com caldo de peixe } \\
\text { ou de carne. }\end{array}$ \\
\hline Mentira Kalunga & Biscoito frito a base de tapioca, ovo, sal e açúcar \\
\hline Mentirinha & Biscoito de tapioca \\
\hline Enrroladinho & Massa de tapioca com ovo assada no forno \\
\hline Paçoca doce & $\begin{array}{l}\text { Farinha de mandioca, gergelim e rapadura } \\
\text { socados no pilão }\end{array}$ \\
\hline
\end{tabular}

Os doces comuns a essa cultura são diversos, e na maioria das vezes à base de frutas nativas do cerrado, mas também podem se apresentar na forma de bolos, biscoitos e 
rosca, como é o caso do enroladinho de tapioca, do biscoito de ovo, da mentira kalunga e da mentirinha. A paçoca doce também é uma comida muito presente no dia-a-dia das famílias Kalungas. Ela pode ser preparada com gergelim ou com as castanhas de cocos nativos, que são misturados à farinha de mandioca e rapadura, e socados no pilão.

Apesar da incrível diversidade de base local, o consumo de produtos alimentares industrializados vem crescendo ao longo dos últimos trinta anos, junto com a monetarização da economia kalunga. As possíveis causas dessa alteração são tratadas no próximo capitulo, mas podemos citar as principais como o turismo, os programas de transferência condicionada de renda, as aposentadorias, empregos públicos locais e prestação de serviços nas cidades próximas.

Todas essas atividades são fonte de entrada de dinheiro para a comunidade, além daquele que é adquirido a partir da venda de seus produtos agrícolas e extrativistas, dinâmica que já existe desde o final da escravidão. Segundo Ungarelli (2009), muito pouco era comprado nas cidades, principalmente utensílios domésticos, ferramentas de trabalho, itens de vestuário, café e sal.

Hoje, esses mesmos itens ainda são adquiridos nas lojas de Cavalcante e Teresina, mas a essa lista se agregaram vários produtos alimentares, nem sempre industrializados, como o óleo de soja, o açúcar branco, o refrigerante, a cenoura e a beterraba (Tabela 19). Como já foi comentado, alguns produtos, como o arroz e o feijão, só são comprados quando findam os estoques familiares, ou quando a família não possui produção agrícola. Com o feijão isso ocorre recorrentemente, principalmente ao final do período seco, já que a produção local não consegue suprir a necessidade total do ano.

Tabela 19 - Principais produtos alimentares comprados nas cidades pelos moradores do quilombo Kalunga (Fonte: Trabalho de campo. Jan/Out de 2014).

\begin{tabular}{llll}
\hline & \multicolumn{2}{c}{ Produtos Comprados } & \\
\hline Processados & Carnes & Frutas e Legumes & Outros \\
\hline Cuscuz & Peixe fresco & Banana* & Sal \\
Café & Carne bovina & Cenoura & Refrigerante \\
Açúcar branco & Carne seca & Beterraba & Cerveja \\
Óleo de soja & Toucinho & Batatinha & Cachaça \\
Macarrão & & Abobrinha & Margarina \\
Arroz* & & \\
Feijão* & & \\
\hline *produtos que só são adquiridos fora quando acabam os estoques familiares. & \\
\hline
\end{tabular}


Contudo, a responsabilidade da chegada de produtos industrializados às cozinhas Kalungas não se deve somente à monetarização da população. A distribuição de cestas tbásicas aos quilombolas é uma prática adotada em muitas partes do país, como estratégia de combate à insegurança alimentar desses grupos, mas que foi reduzida drásticamente com a chegada do programa Bolsa Família, que objetivava homogeneizar e unificar as formas de auxílio às famílias em situação de vulnerabilidade social. Voltar-se-á a essas questões, mas aqui cabe destacar que a Companhia Nacional de Abastecimento (CONAB), por meio da Associação Mãe (AQK), distribui mensalmente um conjunto de alimentos considerados essenciais às famílias. Esses produtos e as suas quantidades são descritos na Tabela 20.

Tabela 20 - Composição da cesta básica distribuída pela CONAB aos moradores do quilombo Kalunga (Fonte: Trabalho de campo. Jan/Out de 2014).

\begin{tabular}{cc}
\hline \multicolumn{2}{c}{ Composição da cesta básica distribuída pela CONAB } \\
\hline $1 \mathrm{~kg}$ de leite em pó & $1 \mathrm{~kg}$ de macarrão \\
$2 \mathrm{~kg}$ de arroz & $1 \mathrm{~kg}$ de fubá \\
$2 \mathrm{~kg}$ de açúcar & $2 \mathrm{~L}$ de óleo de soja \\
$4 \mathrm{~kg}$ de feijão* & $3 \mathrm{~kg}$ de farinha de mandioca fina* \\
\hline
\end{tabular}

Alguns desses alimentos não agradam o paladar kalunga, como a farinha de mandioca (que é considerada muito fina) e o feijão (considerado duro e de sabor ruim). Dessa forma, são corriqueiramente devolvidos à associação ou, como no caso do feijão, dado de ração aos bichos, uma vez que são rejeitados pela maioria das famílias.

De uma forma geral, que envolva ambas as comunidades, podemos definir a cozinha Kalunga como uma gastronomia sertaneja goiana, feita no fogão à lenha, com ingredientes majoritariamente locais, realizada por mulheres. O paladar identitário orbita em torno de ingredientes nativos e sementes crioulas, privilegiando sempre o sabor autóctone em detrimento do exótico, industrial ou artificial.

Entretanto, o contato com o "mundo de fora" vem aos poucos modificando hábitos alimentares da cultura Kalunga, que determinam as dinâmicas produtivas e por fim os sistemas alimentares. As consequências já foram descritas ao longo desta seção, como a troca de sementes crioulas por modificas, o abandono de algumas culturas em função de modificações espaciais, a substituição de produtos artesanais por industrializados e a inserção de novos ingredientes aos preparos diários. Agora falar-se-á a respeito das possíveis influências externas que auxiliam ou determinam tais alterações. 


\section{CAPÍTULO 4 - INFLUÊNCIAS EXTERNAS}

A cultura como objeto de estudo pode ser definida, segundo Geertz (2012), como "o modo de vida global de um povo", "o legado social", "uma forma de pensar, sentir e acreditar" ou "um comportamento aprendido" entre outras coisas. Essas definições carregam em comum o fato de serem processos humanos que se criam e recriam a todo instante, a partir de experimentação, a partir de avaliações coletivas e a partir de processos de autocrítica. A cultura é uma categoria de análise em constante transformação, e deve ser estudada não apenas como um quadro a ser pintado, mas como uma narrativa de todos os equipamentos necessários a pintura assim como a descrição das ações realizadas pelo pintor.

Coloca-se isso a fim de explicar que as mudanças e as transformações da cultura Kalunga são um processo inerente, comum a todas as culturas. Os fatores que podem influencia-la não são culpados, e sim integrantes de um processo em marcha, que podem indicar a direção para onde irão. No caso da cultura alimentar desse grupo, esta pesquisa identificou três fatores principais que colaboram, tanto para sua permanência quanto para as sua transformação. São eles: os programas de transferência de renda condicionada, a distribuição de cestas básicas e o turismo.

Outros fatores também ajudam a impulsionar as mudanças no sistema alimentar Kalunga, como a exposição à mídia, os projetos institucionais ${ }^{5}$ que chegam até a comunidade, facilitação do acesso às cidades próximas, aumento da escolaridade e êxodo rural. Entretanto, as discussões subsequentes não adentrarão tais aspectos, uma vez que extrapolam o escopo da pesquisa e as capacidades da pesquisadora neste mestrado.

\subsection{OS PROGRAMAS DE TRANSFERÊNCIA DE RENDA}

O conceito de sistemas alimentares engloba atividades de produção e atividades de consumo, onde ambas são influenciadas pelas idéias de padrão, estilo e modo de vida almejados. Os anseios que emergem dessas questões perpassam aspectos profundos relacionados com status, direitos fundamentais, liberdade e cidadania, entre outros.

\footnotetext{
${ }^{5}$ Como alguns programas de hortas comunitárias e oficinas de culinária, realizadas em diversos momentos (SEBRAE e Projeto Kalunga Sustentável) que procuram ensinar modelos internacionais de panificação e confeitaria para as cozinheiras locais ao invés de desenvolverem atividades de capacitação a partir da forte culinária local já existente.
} 
Dessa forma, não se deve responsabilizar essa ou aquela influência por aproxima-los de um estilo de vida digno, que outros desejam também. Todos querem liberdades elementares, mas que muitas vezes são negadas pelo mundo atual, como coloca Amartya Sen:

[...] Ás vezes a ausência de liberdades substantivas relaciona-se diretamente com a pobreza econômica, que rouba das pessoas a liberdade de saciar a fome, de obter uma nutrição satisfatória ou remédios para doenças triviais, a oportunidade de vestir-se ou morar de modo apropriado, de ter acesso a água tratada ou saneamento básico. Em outros casos, a privação de liberdade vincula-se estritamente à carência de serviços públicos e assistência social (SEN, 2000, p. 18).

Remover as principais formas de privação de liberdades, como a pobreza, a carência de oportunidades econômicas, negligência dos serviços públicos e a intolerância (SEN, 2000), também é remover a insegurança alimentar, a partir do combate à fome e à pobreza, promovendo a saúde e a inclusão de pessoas em situação de risco e vulnerabilidade social.

Esses também são os objetivos das políticas públicas compensatórias, também chamadas de programas de Transferência Condicionada de Renda (TCR). Esses programas foram pautados na ideia de que o próprio beneficiário é a pessoa mais qualificada para definir qual é a melhor forma de utilizar o benefício, por saber quais são as suas necessidades mais urgentes, e por isso deveria ter autonomia para fazê-lo (SANTANA, 2007).

No Brasil o principal programa de Transferência Condicionada de Renda em vigência é o Programa Bolsa Família (PBF), surgido da unificação, racionalização e ampliação de quatro outros programas sociais que já existiam: o Bolsa Escola, o Bolsa Alimentação, Cartão-Alimentação; e Auxilio-Gás (TRALDI, ALMEIDA e FERRANTE, 2012). Ele foi criado em 2004 para atender famílias em situação de pobreza (com renda mensal por pessoa de $\mathrm{R} \$ 70,00$ a $\mathrm{R} \$ 140,00$ ) ou de extrema pobreza (com renda mensal por pessoa de até $\mathrm{R} \$ 70,00$ ) em todos os municípios do país. Atualmente o programa atende mais de 12 milhões de famílias, das quais 1.939 são quilombolas dos municípios de Cavalcante, Monte Alegre e Teresina (BRASIL, 2014).

O acréscimo de renda para essas famílias, oriundo das políticas públicas compensatórias, possui não só um impacto positivo direto sobre a segurança alimentar das pessoas envolvidas (TRALDI, ALMEIDA e FERRANTE, 2012) como também atua sobre o empoderamento dos membros dessas famílias, aumentando o seu poder de escolha no diadia, dentro e fora de casa (BRAUW et al., 2014). Outros autores ainda destacam que para cada $\mathrm{R} \$ 10$ transferidos por programas como o Bolsa Família, ocorre um aumento de $8 \%$ na 
chance de obtenção de segurança alimentar dentro do domicílio atendido (ANSCHAU, MATSUO e SEGALL-CORRÊA, 2012).

Atualmente existem aproximadamente duas mil famílias dentro do Sítio Histórico Kalunga, das quais 1.271 recebem os benefícios do Programa Bolsa Família. O valor médio do benefício mensal por família é de $R \$ 182,66$ no município de Cavalcante, $R \$ 222,69$ em Teresina e $\mathrm{R} \$ 180,32$ em Monte Alegre, gerando um valor médio de $\mathrm{R} \$ 195,22$ ao longo do território quilombola (MDS, 2014). Apesar de ser um valor baixo, ficando próximo a um quarto do salário mínimo nacional, ainda existem muitos preconceitos relacionados aos programas de TCR. O mais comum deles é facilmente identificável no discurso dos moradores não quilombolas das cidades próximas, que julgam os impactos destes benefícios nos hábitos produtivos da comunidade Kalunga, como representado pelos trechos abaixo:

\begin{abstract}
Eles não plantam mais. Não querem saber de trabalho pesado. Você tenta comprar qualquer coisa deles pra ajudar e não encontra nada, talvez uma farinha de mandioca. [...] Agora que eles têm auxilio do governo, não querem mais saber de ir pra lavoura, não (Voluntária entrevista em Cavalcante, agosto de 2014).

É só andar por ai e ver. Antes eles batiam na porta da gente perguntando se queria comprar farinha, feijão, rapadura, abóbora, melancia, uma porção de coisas, mas hoje eles não têm mais nada pra vender. Compram tudo aqui (em Cavalcante) e levam (Morador de Cavalcante, entrevista realizada em junho de 2014).

É por que não vale a pena, nê? Trabalhar pra que se já recebe dinheiro sem trabalhar mesmo. É só você ir lá e vê. Não tem mais plantio não. Quer dizer, até tem, mas são uns senhorzinhos bem velhos, (que plantam) só pra ele mesmo, não lucra nada (Açougueiro itinerante que acompanha os festejos, entrevistado em agosto de 2014).
\end{abstract}

Esses trechos mostram o mito principal que norteia o preconceito. Ele aparece repetitivamente ao longo das entrevistas realizadas com os moradores da cidade de Cavalcante. Estes moradores defendem que a comunidade Kalunga estaria deixando de produzir seus alimentos ou de que só produziriam a mandioca, para a farinha, mas mesmo assim em pouca quantidade. Além disso, esses trechos já anunciam a relação de causalidade que os entrevistados colocam entre as políticas de transferência condicionada de renda e o abandono das atividades produtivas.

Nestes discursos, acredita-se que a facilidade de aquisição de produtos na cidade, por si só, já seria um fator determinante para o abandono da produção. O segundo argumento seria o fato de que por já receberem algum dinheiro, oriundo dos auxílios do governo, automaticamente cessaria a vontade ou necessidade de se trabalhar nas roças. Aparentemente, na lógica dos moradores da cidade, a motivação da produção agrícola é 
unicamente o comércio, ou seja, a venda de seus produtos em busca de monetarização. Inclusive, o caso do "senhorzinho" que produz unicamente para consumo próprio é visto como pouco vantajoso, uma vez que ele não obtém lucro com essa atividade.

Ao analisarem-se as falas dos entrevistados percebe-se que a falta de produtos quilombolas no comércio local é o principal, ou talvez o mais óbvio, indicador que induz ao pensamento de escassez. Se falta no mercado, ou se os produtores não vendem, subentende-se que não devem existir mais. Entretanto, como foi relatado nos capítulos anteriores, vimos que as atividades produtivas Kalungas permanecem ocorrendo em ambas as comunidades estudadas. Também podemos verificar isso nos dados do SEPPIR/Fubra, citados anteriormente (Tabela 21), que apontam na mesma direção, indicando que quase $74 \%$ da população Kalunga ainda têm as roças como fonte de renda.

Tabela 21 - Distribuição percentual dos domicílios, segundo a origem dos recursos financeiros (Fonte: SEPPIR/Fubra, 2004)

\begin{tabular}{lcc}
\hline Fonte dos Recursos & Possui & Não possui \\
\hline Aposentadoria & $28,83 \%$ & $71,17 \%$ \\
Venda/produção de artesanato & $25,42 \%$ & $74,58 \%$ \\
Qualquer programa social & $12,23 \%$ & $87,77 \%$ \\
Coleta de frutas/madeira no mato & $7,47 \%$ & $92,53 \%$ \\
Roça & $73,99 \%$ & $26,01 \%$ \\
Criação de animais & $50,42 \%$ & $49,58 \%$ \\
Dinheiro recebido pelo trabalho & $44,25 \%$ & $55,75 \%$ \\
Garimpo & $2,02 \%$ & $97,98 \%$ \\
\hline
\end{tabular}

Devido, principalmente, ao dinheiro gerada pelo turismo, cada localidade apresenta um porcentual diferenciado de suas rendas oriundo do PBF, variando de $10 \%$ à $22 \%$, como indicado na Figura 28. É importante destacar, que em nenhuma das localidades existe uma regularidade referente ao turismo, que será tratado adiante, assim como não existe uma regularidade produtiva anual, uma vez que a agricultura de corte e queima depende intimamente das variações climáticas. Isso significa que a renda familiar varia de acordo com as estações, sendo mais dependente do extrativismo ao longo da seca, e mais dependente da agricultura na estação chuvosa. O gráfico abaixo foi produzido a partir de uma média anual da renda dos entrevistados.

Das seis famílias entrevistadas na comunidade Engenho II, apenas uma não estava diretamente envolvida com o turismo. Nessa família, as origens da renda familiar se equiparavam as das famílias residentes do Vão de Almas, que também representam melhor 
a realidade do território de uma maneira geral, pois como já foi dito, o Engenho configura uma realidade diversa, contando com melhores condições de infraestrutura, educação, saúde e geração de renda.

A partir desses dados notam-se também os diferentes impactos do PBF, que representa $22 \%$ da renda familiar no Vão de Almas, contra apenas $10 \%$ no Engenho II. Contudo, o valor bruto oriundo do dinheiro recebido pelo trabalho e pelas atividades agrícolas não difere muito de uma comunidade para a outra, mas impacta de forma diferente, uma vez que o turismo é a principal fonte de renda para uma comunidade, enquanto a agricultura e o extrativismo o são para a outra. $O$ valor médio encontrado para a renda familiar mensal no Vão de Almas foi de $R \$ 1.022,00$, enquanto que no Engenho esse valor subia para $\mathrm{R} \$ 1.932,00$.

\section{Engenho II}

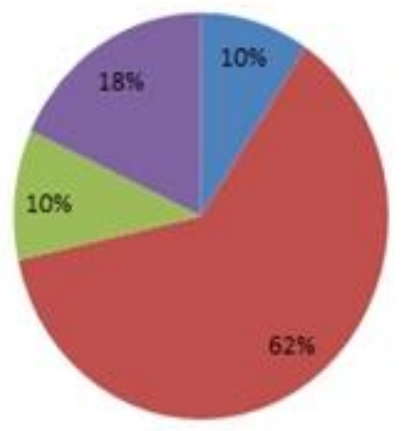

Vão de Almas

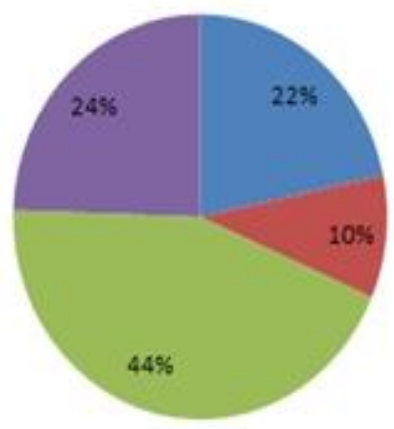

Eolsa familia

- Turismo

Iivendas de produtos agricolas e extrativistas Dinhe iro recebido por trabalho

Figura 28 - Porcentagem da renda em relação às atividades econômicas das 11 famílias entrevistadas.

Estimando-se uma média de cinco a seis pessoas por família, ambos os grupos amostrais estão fora da classificação de pobreza ou extrema pobreza. Atualmente, é o benefício do Bolsa Família que garante que as famílias entrevistadas no Vão de Alma estejam fora dessa situação. Embora a principal fonte de renda dessa localidade seja a produção agroextrativista, é o auxilio governamental que minimiza a situação de vulnerabilidade das famílias, que só com o dinheiro oriundo dos serviços prestados, do turismo, da agricultura e do extrativismo não seriam capazes de se manterem acima da linha da pobreza. A vulnerabilidade à insegurança alimentar está intimamente relacionada com os domicílios de baixa renda, "que tem pouca disponibilidade ou pouco acesso aos alimentos, 
condição de utilização biológica inadequada, além de distribuição desigual entre os membros da família" (ANSCHAU, MATSUO e SEGALL-CORRÊA, 2012, p. 179)

Os beneficiários pesquisados são produtores rurais que preferem permanecer com suas produções agrícolas ao invés de vendê-las. Isso pode levantar o questionamento quanto a destinação dada para os $22 \%$ a mais de renda que as famílias do território adquiriram a partir do surgimento do PBF. As necessidades mais recorrentes desses grupos, que são supridas com o auxílio, são: a falta de mão de obra (por meio da contratação de ajudantes), medicamentos, material escolar, produtos alimentícios, roupas e utensílios domésticos.

Os dois relatos abaixo demostram um pouco das necessidades que existiam, ou que eventualmente existem, e as formas como o benefício vem ajudando-os.

[...] se faz um ano que num chove quase nada e dá muito sol, ai nois tem que ir na cidade e comprar arroz e feijão, por que ai não dá pro ano todo. Mas é caro e ruim, num tem o mesmo gosto do daqui. É melhor usar o nosso mesmo (Morador do Engenho II).

[...] antes quando de adoecer um parente nosso, nois tinha que ir até a cidade comprar ás vezes um remédio, ou ás vezes uma roupa. Ai nois descia levando as saca de farinha, de feijão pra vender. Chegava lá nois tinha que aceitar o que queria pagar, tinha povo que tentava enganar nois, ne. Ai pra voltar logo aceitava e rumava pra casa (Moradora do Engenho II).

A possibilidade de decidir sobre as próprias prioridades é um fator essencial para que os agricultores Kalungas possam permanecer com a sua produção, mais saborosa e nutritiva, ao invés de vendê-la a preços baixos a fim de suprir necessidades básicas, como aquisição de remédios ou roupas. Assim, constatou-se que os auxílios governamentais, como o programa Bolsa Família, diminuem a vulnerabilidade das famílias estudadas, permitindo que elas gerenciem melhor os seus recursos.

Isso implica empoderamento e poder de escolha sobre a destinação da sua produção agrícola. Seja na comunidade Engenho II ou no Vão de Almas, a escolha é por não se vender os produtos, que são considerados de qualidade superior aos encontrados nos mercados. Dessa forma, a alimentação é apenas complementada por produtos industrializados adquiridos na cidade. Essas alterações relacionadas ao poder de escolha diminuem a vulnerabilidade nutricional dos Kalungas, aumentando a diversidade de alimentos que podem ser adquiridos e garantindo uma maior regularidade deles à mesa.

Por fim podemos dizer que sim, os produtos Kalungas sumiram do mercado, como os moradores de Cavalcante bem perceberam, mas não porque deixaram de ser produzidos. Eles agora se encontram nas mesas de seus donos ao longo de todo o ano, cumprindo sua 
função nutricional local. Desta modo encontra-se mais uma forma pela qual o PBF amplia as possibilidades de segurança alimentar das famílias mais vulneráveis.

Aos moradores da cidade pode parecer estranho essa decisão da não-venda dos produtos, mas ao analisarmos os relatos dos agricultores, percebemos que é a escolha mais segura, do ponto de vista alimentar, e a mais saborosa, do ponto de vista do paladar Kalunga. Ao contrário do pensamento comum a respeito das bolsas, que supõem o abandono das atividades laborais, nas famílias estudadas esse comportamento não se verifica. Ao invés disso, os programas sociais auxiliam ajudando que o trabalhador rural possa continuar suas atividades voltadas para a subsistência sem comprometer a segurança alimentar da sua família.

\subsection{AS CESTAS BÁSICAS}

As famílias que residem no território Kalunga contam com outro auxílio governamental, além do PBF: as são cestas básicas oriundas da CONAB e distribuídas pela Associação Mãe às famílias cadastradas. Essas cestas fazem parte de um conjunto de ações governamentais que visam "garantir de forma regular, um composto alimentar a grupos populacionais específicos em situação de vulnerabilidade social" (BRASIL, 2014b). Dentro dos grupos vulneráveis escolhidos estão os quilombolas Kalungas. As cestas são entregues na cidade de Cavalcante, e as famílias precisam retirá-las na sede da associação.

Apesar de ser uma ação que contribui para a garantia da alimentação mensal das famílias, é preciso que se comente a respeito dos produtos que a compõem, já listados acima, na Tabela 20. Apesar de conter ingredientes fundamentais para a dieta Kalunga, como o arroz, o feijão e a farinha de mandioca, ela também insere na alimentação dessas famílias elementos antes estranhos a sua gastronomia, além de industrializados, como o óleo de soja e o macarrão. Além disso, os produtos já familiares ao paladar local são de qualidade muito inferior ao que os agricultores quilombolas estão acostumados a ingerir, causando um desagrado generalizado. Essa incompatibilidade gustativa, leva os moradores a rejeitarem certos produtos da cesta, como relata um dos beneficiários:

Eu não levo o feijão nem a farinha que é muito fina. Num serve pra cozinha, talvez um bolo, mas não é boa. O feijão é complicado, não é. Num cozinha de jeito nenhum, ruim que só, tem gosto de qualquer coisa só num é de feijão. Mas ai eu não levo, deixo pra quem tenha precisancia maior. Nois num ta precisando desse jeito, tem família que ta. Ai nois deixa lá pra quem precisar mais pega (Morador do Vão de Almas).

Além de abandonar alguns elementos da cesta, outros moradores relatam que a recusa do feijão é tanta, que muitas vezes as famílias só o usam de ração para os animais: 
Fica lá parado, num tem ninguém que goste. Tem mês que sobra é muito, mês de chuva, quando dá pra planta. Ai sobra é um bucado. Mas quando falta na roça nois levava pra casa, mas não tinha jeito, o trem é ruim mesmo, num cozinha de jeito nenhum, o nosso (feijão) é só coloca na panela e rapidinho ta pronto. Esse passa é mais de hora e nada! Ai nois dava pros porcos, joga fora não ia, ai dava pros bicho (Moradora do Vão de Almas).

As politicas de segurança alimentar precisam, além de atender requisitos ligados à produção, distribuição, acesso e consumo, estarem ligadas a elementos e/ou valores fundamentais da população como: a) saúde, b) higiene, c) meio ambiente, d) autenticidade e e) solidariedade (TRALDI, ALMEIDA e FERRANTE, 2012). Ainda segundo esses autores, o eixo da autenticidade deveria estar "ligado aos valores naturais e tradicionais da produção da produção agroalimentar, aos conhecimentos muitas vezes herdados de práticas alimentares, à valorização da origem dos produtos e às especificações dos processos produtivos" (p.27).

Observa-se então, que apesar da cesta básica cumprir com uma parte do objetivo desse tipo de política pública, a sua composição desrespeita o quesito da autenticidade, oferecendo alimentos que não estão de acordo com os valores alimentares Kalungas, como por exemplo produtos com agrotóxicos, e que desrespeitam o paladar identitário e as tradições gastronômicas dessa população. Os alimentos ofertados aumentam a quantidade de alimentos disponíveis mensalmente para as famílias, mas em detrimento da tradição culinária local e do prazer alimentar dos seus consumidores.

\subsection{O TURISMO}

O nordeste do Goiás, apesar de ser a região mais pobre do estado, guarda um grande potencial turístico devido aos seus atrativos naturais. Um dos pontos que atraem mais turistas é a Chapada dos Veadeiros, uma área rica em beleza cênica e repleta de cachoeiras e rios, o que tem estimulado o crescimento do turismo ecológico, principalmente após a criação do Parque Nacional da Chapada dos Veadeiros (PNCV), no ano de 1961. O município da Cavalcante guarda grande parte de sua área, fazendo-o vizinho do Sítio Histórico e Cultural Kalunga.

O Território Kalunga, com quatro vezes a área do PNCV, guarda inúmeros atrativos naturais, como a Cachoeira Santa Bárbara, na comunidade do Engenho II, recentemente eleita uma das mais bonitas do Brasil, atraindo centenas de turistas diariamente durante a alta temporada. Essa valorização de áreas consideradas selvagens pode ser encarada como alternativa para o desenvolvimento econômico sustentável regional (LIMA, 2013) gerando "renda, capacitação e inclusão social para as populações locais residentes no 
entorno de unidades de conservação de proteção integral ou mesmo no interior de unidades de conservação de uso sustentável” (FRANCO, 2011).

Além dos atrativos naturais, o Sítio Histórico e Cultural Kalunga abriga várias festividades religiosas ao longo do ano (Tabela 4) que aos poucos veem atraindo o turismo cultural para a região. Uma das folias mais conhecidas é a Festa de Nossa Senhora D’Abadia, que ocorre no mês de agosto, na comunidade de Capela da região do Vão de Almas. Diversas pesquisas se aprofundaram na atividade turística local, como Sirico (2008), Lima e Almeida (2011) e Campos (2011).

Esses dois tipos de turismo, o ecológico e o cultural, caracterizam bem os estremos opostos que se encontram as duas comunidades estudadas no que diz respeito às atividades econômicas relacionadas. O engenho apresenta um fluxo de turistas constante durante toda a estação seca e esporádico durante a estação chuvosa. O acesso aos atrativos desse povoado é realizado mediante pagamento de entrada ( $R \$ 10,00)$ e da contratação de um guia local $(\mathrm{R} \$ 50,00)$. Em feriados nacionais, a procura é tão intensa que chegam a faltar guias e espaços livres nos atrativos, o que forçou a criação de uma "capacidade de carga máxima diária" dos atrativos.

O turismo no Vão de Almas é muito distinto, se concentrando apenas no mês de agosto e é focado nas festividades religiosas e as cerimonias que as acompanham. Não existe cobrança de taxa de entrada ou necessidade de guias, mas a estrada é de difícil acesso e muitas vezes a contratação de um transporte $4 \times 4$ se faz necessária. O poder aquisitivo dos turistas dessa localidade também é muito distinto dos que procuram o Engenho II. São moradores do território Kalunga, moradores da região do entorno do Sítio, ou, quando muito, turistas de Goiânia ou Brasília. A movimentação econômica se dá predominantemente ao redor das comidas típicas e exóticas, além das bebidas alcóolicas, consumidas em abundância.

Os impactos econômicos desses dois modelos turísticos são muito distintos entre as duas comunidades, como mostra a Figura 28. Enquanto os atrativos naturais da região do Engenho geram um fluxo constante de renda aos seus moradores, contribuindo com uma média de $68 \%$ da renda das famílias envolvidas com o turismo, no Vão de Almas essa porcentagem desce para menos de $10 \%$. Por mais que o valor bruto adquirido durante os dias de festa seja alto (chegando a $R \$ 1.500,00$ em cinco dias), essa entrada não se repete ao longo do ano e, quando muito, um morador é chamado para realizar guiagens pela região, duas vezes ao ano. 
Assim, os benefícios oriundos do turismo são muito maiores no Engenho, chegando a representar mais da metade da renda familiar, além de fornecer um poder aquisitivo quase $50 \%$ maior aos seus moradores, se comparados com a outra área estudada. Entretanto o fluxo alto de turistas também traz consequências negativas para a comunidade, como o desgaste acelerado dos atrativos turísticos. No Vão de Almas os principais problemas advindos do turismo são a poluição do rio, o acúmulo de lixo no local do festejo e o consumo e comercio de drogas lícitas e ilícitas.

Conclui-se que o turismo contribui para a diminuição da insegurança alimentar no território Kalunga, contudo essa contribuição não é igual para todas as localidades, sendo predominantemente exercida na localidade do Engenho. Entretanto, mesmo na Região do Vão de Almas, onde essa atividade só vigora um mês por ano, a renda bruta adquirida pelos moradores que se dispõem a trabalhar no festejo, é equivalente a trinta dias de guiagens, o que equivale a 10 finais de semanas do Engenho. Essa entrada pontual de dinheiro, que ocorre no mês de agosto no Vão, auxilia na redução da insegurança alimentar de seus moradores, na medida em que esses se utilizam do dinheiro na aquisição de bens de consumo mais caros, como eletrodomésticos, permitindo que a renda dos outros meses permaneça aplicada nas necessidades alimentares e nutricionais da família. Isso permite às famílias investirem na transformação dos produtos agrícolas, produzindo geleias, doces, óleos e polpas.

\subsection{ALTERAÇÕES E PERMANÊNCIAS DO SISTEMA ALIMENTAR KALUNGA}

$\mathrm{Na}$ busca do perfil alimentar Kalunga, encontraram-se também as características da comunidade que se alteraram e aquelas que permaneceram, assim como suas possíveis origens. Todas elas já foram abordadas ao longo do trabalho, mas serão agora sistematizadas e discutidas (Tabela 22).

A comunidade do Engenho II pode ser vista como uma síntese de todas as grandes mudanças que esses quilombolas veem sofrendo ao longo das últimas décadas. Vários fatores contribuíram para que ele se se tornasse o que é hoje, como a abertura de estradas, turismo frequente, grande número de projetos sociais, energia elétrica, infraestrutura, escolas e posto de saúde. Entretanto, essa também é uma comunidade que destoa das restantes, já que quase todo o território Kalunga apresenta padrões próximos aos do Vão de Almas. Listar-se-á agora as principais causas e alterações referentes aos sistemas alimentares desse povo. 
A respeito dos programas assistenciais de transferência condicionada de renda, ambas as comunidades recebem o benefício, mas ele tem maior relevância no orçamento das famílias do Vão, chegando a $22 \%$ da renda mensal. Mostramos que esses programas incentivam a manutenção das atividades agrícolas voltadas para o autoconsumo, fornecendo ao produtor rural o poder de escolha sobre a destinação de sua produção, ao invés de ser obrigado a vendê-la em busca de dinheiro para o auxílio de questões básicas, como remédios, material escolar e vestimenta. Essa questão também poderia ser encarada como uma mudança, uma vez que até pouco tempo o direito de permanecer com seus produtos estava enfraquecido nas comunidades, mas agora retorna com a complementação monetária que o benefício oferece.

O turismo traz para a comunidade Kalunga uma nova estratégia de geração de renda, que pode ser desenvolvida de forma a promover um desenvolvimento sustentável para a comunidade. Entretanto, os benefícios oriundos dessa atividade não se espalham de forma homogênea sobre o território, se concentrando principalmente nos atrativos do Engenho. Essa situação pode se alterar caso haja investimentos voltados para a divulgação e implementação de infraestrutura de novos atrativos, pois o território conta com diversas outras belezas cênicas.

$\mathrm{Na}$ comunidade do Engenho, a renda oriunda do turismo pode representar quase $70 \%$ do orçamento das famílias que se propõem a integrarem essa nova atividade econômica, e mesmo no Vão de Almas, onde o turismo é pouco e esporádico, a renda gerada pode trazer benefícios rápidos às famílias participantes. De forma indireta, o turismo proporciona a venda de produtos extrativistas por valores mais justos, como no caso dos óleos artesanais, polpas de frutas e legumes que são comercializados nas feiras locais e nos receptivos turísticos da cidade.

Tabela 22 - Quadro síntese das alterações de cada uma das comunidades estudadas (Fonte: Trabalho de campo, 2014).

\begin{tabular}{lll}
\hline \multicolumn{2}{c}{ Quadro Síntese dos } & Aspectos Contrastante entre as Duas Comunidades \\
\hline & Engenho II & Vão de Almas \\
\hline Programas assistenciais & Possui & Possui \\
Turismo & Forte e constante ao longo do ano & Fraco e concentrado em um mês \\
Dinâmica espacial das casas & Aglomeração espacial em torno de & Dispersão e invisibilidade ao longo \\
& um "núcleo" & do território \\
Distribuição espacial das roças & Distantes e de difícil acesso & Próximas e de fácil acesso \\
Principais Culturas & Arroz e feijão & Mandioca, feijão de corda e arroz \\
Cestas Básicas & Recebe & Recebe \\
\hline
\end{tabular}


A dinâmica espacial das casas é uma das alterações mais evidentes no povoado Engenho. Nessa localidade a instalação de infraestrutura, como luz, posto de saúde e escola, estimulou a aglomeração das famílias em um pequeno núcleo, que hoje já abriga mais de 120 famílias. Essa dinâmica permitiu a instalação de mercadinhos onde alguns produtos são adquiridos, mas também facilita a troca entre as famílias, principalmente de produtos perecíveis, como folhagens e verduras, ovos, leite e carnes. A aglomeração também facilita o escoamento da produção, ou o fretamento de carros para o transporte de produtos da cidade até a comunidade.

Entretanto, essa disposição espacial das famílias se deu em decorrência da grilagem de suas terras, forçando que as famílias se aglomerassem em áreas seguras, mas ficando afastadas de suas áreas produtivas. Durante certo período de tempo esse afastamento implicou em suspensão das atividades agrícolas para algumas famílias, que estavam com suas terras ocupadas, para outras significou uma jornada mais longa até as suas terras, além de prejudicar o processamento e armazenamento dos produtos agroextrativistas.

Esse distanciamento geográfico das áreas de roça levou ainda a algumas alterações nos produtos escolhidos para o plantio. Como no caso do Engenho, que teve uma significativa redução da produção da farinha de mandioca como consequência do afastamento das roças e casas. Ou seja, a grilagem das terras expulsou as famílias de junto das roças, alterando a dinâmica espacial das áreas produtivas, o que determinou a disposição dos núcleos familiares em relação à produção e escoamento, e que, por fim, influenciou na escolha de algumas das variedades cultivadas. Essa cascata de acontecimentos que o Engenho passou nos últimos 30 anos dá uma breve ideia dos impactos que a questão fundiária pode ter sobre os sistemas alimentares tradicionais.

No Vão de Almas, onde a dinâmica espacial permanece a mesma, os cultivos principais se mantiveram, mas nota-se uma gradual substituição das sementes locais por variedades novas, assim como em outras partes do território Kalunga. Essa dinâmica, junto a outras, como a origem das variedades distribuídas na cesta básica, levanta a seguinte questão: A insegurança alimentar está sendo aos poucos suprimida na comunidade Kalunga, mas será que a tradição e a independência dessa comunidade está sendo respeitada, e visada, nesse processo? 


\section{CAPÍTULO 5 - SEGURANÇA ALIMENTAR}

A segurança alimentar se pauta no direito ao acesso regular e permanente a alimentos de qualidade, em quantidade suficiente, de forma que não se comprometa o acesso a outras necessidades essenciais, tendo como base práticas alimentares que promovam a saúde e que respeitem a diversidade cultural e que sejam social, econômica e ambientalmente sustentáveis. Os princípios enunciados acima devem estar presentes em todas as ações que visem eliminar a fome ou a insegurança alimentar e nutricional, mas nem sempre se consegue atender a todas as prerrogativas simultaneamente. Essas lacunas de planejamento advindas de políticas públicas pré-prontas, geram efeitos colaterais que geralmente incidem sobre as culturas locais.

\subsection{SEGURANÇA ALIMENTAR KALUNGA}

A fim de compreender melhor essas questões na comunidade Kalunga, foi aplicado nas onze famílias entrevistadas o questionário da Escala Brasileira de Medida de Insegurança Alimentar (EBIA), um método investigativo adaptado de pesquisas americanas para os hábitos brasileiros. Esse método se baseia em quinze perguntas, que devem ser respondidas com sim ou não. De acordo com as respostas, os avaliados podem ser classificados em quatro categorias, já citadas anteriormente: Segurança Alimentar (SA), Insegurança Alimentar Leve (IAL), Insegurança Alimentar Moderada (IAM) e Insegurança Alimentar Grave (IAG). As perguntas estão listadas na Tabela 23.

Tabela 23 - Perguntas Utilizadas para avaliar a insegurança alimentar a partir da EBIA. (SEGALL-CORREA e SALLES-COSTA, 2008)

\begin{tabular}{|c|c|}
\hline \multicolumn{2}{|r|}{ Perguntas do EBIA } \\
\hline 1 & Preocupação que a comida acabasse antes que tivesse condição de comprar mais. \\
\hline 2 & A comida acabou antes que tivesse dinheiro para comprar mais? \\
\hline 3 & Ficou sem dinheiro para ter uma alimentação saudável e variada? \\
\hline 4 & $\begin{array}{l}\text { Dispõe de apenas alguns tipos de alimentos para alimentar os(as) moradores(as) com } \\
\text { menos de } 18 \text { anos porque o dinheiro acabou? }\end{array}$ \\
\hline 5 & $\begin{array}{l}\text { Adulto(a) diminuiu a quantidade de alimentos ou pulou refeições porque não havia } \\
\text { dinheiro para comprar comida? }\end{array}$ \\
\hline 6 & $\begin{array}{l}\text { Comeu menos do que achou que devia porque não havia dinheiro suficiente para } \\
\text { comprar comida? }\end{array}$ \\
\hline 7 & Entrevistado(a) sentiu fome, mas não comeu porque não podia comprar comida? \\
\hline 8 & $\begin{array}{l}\text { Entrevistado(a) perdeu peso porque não tinha dinheiro suficiente para comprar } \\
\text { comida? }\end{array}$ \\
\hline 9 & Adulto(a) ficou um dia inteiro sem comer ou teve apenas uma refeição ao dia porque \\
\hline
\end{tabular}




\begin{tabular}{|c|c|}
\hline & não havia dinheiro para comprar comida? \\
\hline 10 & $\begin{array}{l}\text { Não pôde oferecer a algum(a) morador(a) com menos de } 18 \text { anos alimentação } \\
\text { saudável e variada porque não tinha dinheiro? }\end{array}$ \\
\hline 11 & $\begin{array}{l}\text { Algum(a) morador(a) com menos de } 18 \text { anos não comeu em quantidade suficiente } \\
\text { porque não havia dinheiro para comprar comida? }\end{array}$ \\
\hline 12 & $\begin{array}{l}\text { Diminuiu a quantidade de alimentos das refeições de algum(a) morador(a) com menos } \\
\text { de } 18 \text { anos porque não havia dinheiro suficiente para comprar comida? }\end{array}$ \\
\hline 13 & $\begin{array}{l}\text { Algum(a) morador(a) com menos de } 18 \text { anos deixou de fazer alguma refeição porque } \\
\text { não havia dinheiro para comprar comida? }\end{array}$ \\
\hline 14 & $\begin{array}{l}\text { Algum(a) morador(a) com menos de } 18 \text { anos teve fome, mas você simplesmente não } \\
\text { podia comprar mais comida? }\end{array}$ \\
\hline 15 & $\begin{array}{l}\text { Algum(a) morador(a) com menos de } 18 \text { anos ficou sem comer por um dia inteiro } \\
\text { porque não havia dinheiro para comprar comida? }\end{array}$ \\
\hline
\end{tabular}

De acordo com o resultado da escala, as famílias do Vão de Almas (todas as entrevistadas) possuem insegurança alimentar leve, baseado na resposta da questão 1 e da questão 3. Isso mostra que a principal fonte da insegurança alimentar dessa comunidade está relacionada à qualidade e variedade do alimento, assim como a inconstância produtiva ao longo do ano. A pergunta 1, "Preocupação que a comida acabasse antes que tivesse condição de comprar mais" foi em todos os casos precedida de argumentos como "na seca rareia" e "Na chuva não, mas quando para a chuva preocupa", o que indica a alternância de períodos de abundância e de escassez de acordo com alteração do clima, como é típico das comunidades agroextrativistas.

A terceira pergunta, "Ficou sem dinheiro para ter uma alimentação saudável e variada?", foi marcada em quatro das cinco famílias entrevistadas no Vão. Ela corrobora com outras evidencias que apontam para o fato de que hoje em dia a insegurança alimentar vem diminuindo na região, em decorrência da quantidade de alimentos disponíveis ser maior (Bolsa Família e Cestas Básicas). Entretanto, uma maior ingestão de alimentos não significa necessariamente a ingestão de alimentos nutritivos, saudáveis ou variados. $\mathrm{Na}$ realidade, estudos recentes, como o da pesquisadora Cordeiro (2013), mostram que os padrões de insegurança alimentar atuais têm se deslocado da desnutrição para a obesidade, antes vista como sinónimo de abundância.

Ela explica que há cada vez mais evidencias que relacionam a insegurança alimentar com o sobrepeso e a obesidade, já que a qualidade dos alimentos consumidos deixa muito a desejar. A grande disponibilidade de alimentos de alta densidade calórica vendidos por preços acessíveis nas cidades podem ser tão responsáveis pela ausência da SAN como a falta de alimentos em quantidade e variedade adequados (CORDEIRO, 2013). 
Como já se demostrou, a comunidade do Engenho II destoa dos padrões do restante do território, favorecendo-se em grande medida com a renda oriunda do turismo e das vantagens de infraestrutura que possui. Nessa comunidade uma família apresentou insegurança alimentar moderada, outra apresentou insegurança alimentar leve e as quatro restantes apresentaram segurança alimentar.

O caso que desvia do padrão, referente à família que se encontra em situação de insegurança alimentar moderada, decorre de uma história particular. Essa família não é originária da comunidade Engenho II, tendo suas roças e residência principal na comunidade do Vão de Almas. Entretanto, no ano anterior as safras não foram boas por falta de chuva, o que levou essa família a trabalhar como meeira na roça de conhecidos do Engenho. Além dos infortúnios climáticos, a família também não se interessa em participar das atividades econômicas relacionadas ao turismo, o que torna a realidade financeira dessa família completamente distinta das outras entrevistadas na mesma região.

Se somarmos os resultados obtidos, encontraremos que $34 \%$ dos informantes se encontram em situação de segurança alimentar, seguidos de $58 \%$ em situação de insegurança alimentar leve, e $8 \%$ com insegurança alimentar moderada (Figura 29). Os resultados encontrados indicam uma possível alteração e/ou divergência das colocações feitas no artigo da pesquisadora Valente (2007), que alerta para a situação de extrema pobreza e insegurança alimentar grave da comunidade. Acredita-se que essa divergência ocorra devido à amostragem da pesquisa. A escolha unicamente por famílias produtoras agrícolas já fornece aos resultados da pesquisa um desvio da curva padrão da comunidade. Apesar de ser o modelo econômico padrão dessa população, é cada vez maior o número de famílias que desistem desse sistema produtivo. As razões variam, mas envolvem principalmente o êxodo rural, falta de mão de obra (filhos vão embora), dificuldade de escoamento da produção, e condições climáticas alteradas (segundo a percepção local).

Desse modo, o grupo amostral escolhido apresenta uma vantagem sobre a segurança alimentar que muitas outras famílias não mais possuem: a sua própria produção de alimentos básicos, pautada sobre uma diversificação da renda em multilocalidades. Essas famílias dependem menos dos produtos industrializados e comercializados nas cidades, além de serem menos prejudicadas com as varrições dos preços de tais produtos. Além disso, as famílias que mantem roças, mantem um estoque maior de produtos que são tipicamente associados aos roçados, como a abóbora, o jiló, o maxixe, o quiabo e a banana. Além de ser uma combinação de diferentes atividades, esse modelo de diversificação de renda está sustentado por diversos locais dentro da comunidade, como as roças, pastos, 
pomares, hortas e matas, que comumente fazem parte de um arranjo coletivo de propriedade

\section{Porcentagem de Segurança Alimentar}

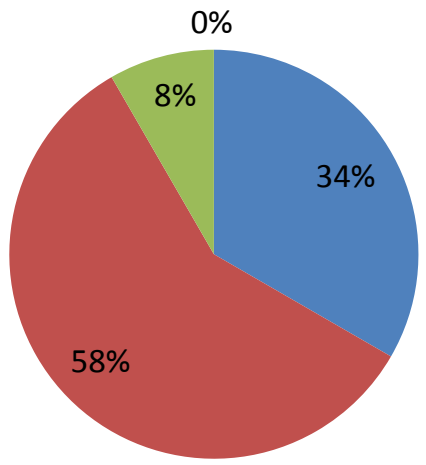

- Segurança Alimentar

Insegurança Alimentar Leve

- Insegurança Alimentar Moderada

Insegurança Alimentar Grave

Figura 29 - Porcentagem das famílias em relação ao estado de segurança alimentar, somando-se as duas localidades (Fonte: Trabalho de campo. Jan/Out de 2014).

A combinação Bolsa Família, cesta básica, produção agrícola (roça), extrativismo e o turismo (em menor medida) amenizam os fatores que levam à insegurança alimentar, aproximando essas famílias de uma situação de Segurança Alimentar e Nutricional que outras não possuem. De acordo com a EBIA, a insegurança alimentar leve é caracterizada por uma preocupação ou incerteza quanto ao acesso aos alimentos e um comprometimento da qualidade. Isso é exatamente o que verificamos nas famílias estudadas, não tanto a quantidade de alimento, mas a qualidade dos produtos que chegam até as mesas.

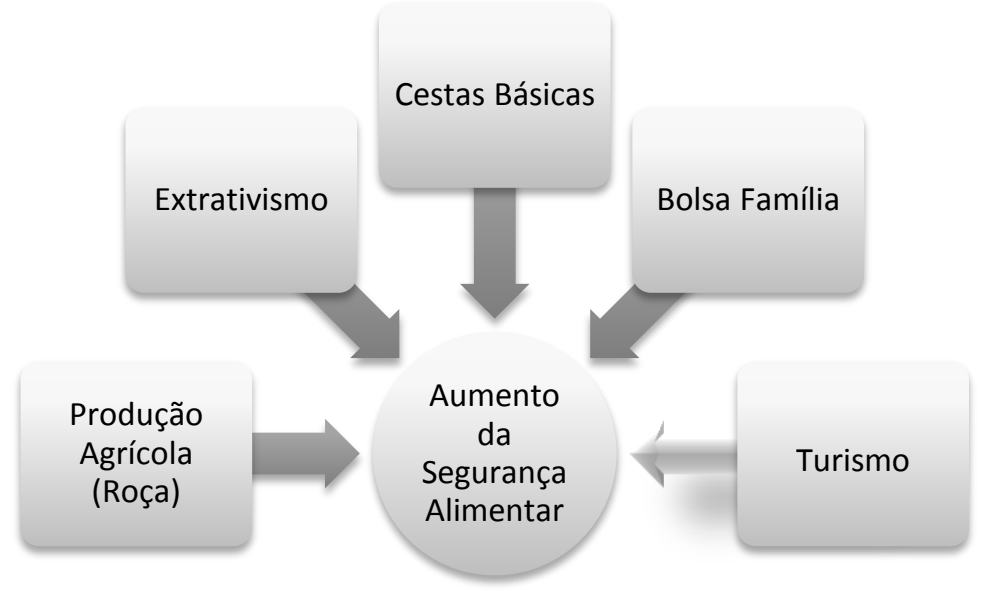

Figura 30 - Desenho esquemático das atividades que podem, de forma combinada, aumentarem a segurança alimentar das comunidades Kalungas (Fonte: Trabalho de campo. Jan/Out de 2014). 
Essa discussão também retorna ao critério "autenticidade", comentado anteriormente (item 4.2), onde os valores naturais e tradicionais dos produtos devem ser respeitados quando do estabelecimento de projetos referentes à segurança alimentar. Mas se o acesso a alimentos está aumentando, quais fatores estão sendo deixados de fora, relacionados à origem, qualidade, sabor e nutrição dos alimentos, que impede as famílias de atingirem uma situação de segurança alimentar plena? O presente estudo indica que o crescimento da segurança alimentar, quando não é acompanhado da construção da soberania alimentar, impede que a primeira seja completamente sanada, como será abordado no tópico seguinte.

\subsection{SEGURANÇA ALIMENTAR VERSUS SOBERANIA ALIMENTAR}

Ate o momento escolheu-se utilizar apenas o termo segurança alimentar ao longo do trabalho em função de ser esse o objetivo anunciado e clamado por todos os projetos, bolsas e ações governamentais em voga atualmente na comunidade Kalunga. Entretanto os princípios que não estão sendo respeitados, ao longo dos processos de redução da insegurança alimentar, são exatamente aqueles que garantem que a comunidade não retorne ao estado de vulnerabilidade caso os benefícios sejam retirados. Eles dizem respeito ao aspecto da soberania alimentar local.

O conceito de soberania alimentar surge como um contraponto que postula que para ser livre um povo precisa ser soberano sobre os seus recursos, e essa soberania necessariamente perpassa a esfera alimentar. A definição oficial de soberania alimentar, enunciada em 1996, pela Via Campesina Internacional, afirma que ela é:

[...] o direito dos povos a definir suas próprias políticas e estratégias sustentáveis de produção, distribuição e consumo de alimentos, que garantam o direito à alimentação a toda a população, com base na pequena e média produção, respeitando suas próprias culturas e a diversidade dos modos camponeses de produção, de comercialização e de gestão, nos quais a mulher desempenha um papel fundamental (VIA CAMPESINA, 2007).

Também significa comercializar e produzir alimento localmente de forma integrada com as culturas locais, afastando-se da dependência dos grandes mercados internacionais. Eliminar intermediários entre a comida e o consumidor, possibilitando que os povos tenham total controle sobre seus sistemas alimentares são os princípios norteadores da soberania alimentar.

Apesar de observar-se que a bolsa família e as cestas básicas, quando acompanhadas de estratégias variadas, como a agricultura e o extrativismo, aumentam a segurança alimentar das famílias Kalungas, elas também criam, muitas vezes, uma situação 
de dependência com comércios externos de produtos desvinculados da cultura local, onde os alimentos são industrializados, homogêneos e de baixa qualidade nutricional e ambiental. Esses produtos geralmente fazem parte de uma economia de mercado, "na qual a fome e a desnutrição não podem ser superadas se o conjunto de consumidores não dispuser de renda suficiente para garantir a satisfação de suas necessidades alimentares" (CHONCHOL , 2005). Ou seja, a fome é muito mais um produto da marginalização econômica do que da insuficiência produtiva dos mercados, que atualmente geram mais comida do que seria necessário para alimentar toda a população mundial.

Ao analisar a situação Kalunga consegue-se constatar que é possível aumentar a segurança alimentar e nutricional de populações sem necessariamente aumentar ou construir a soberania alimentar dessas pessoas. Entretanto, o inverso não ocorre, não é possível que haja soberania alimentar sem que a segurança alimentar caminhe junto. $O$ conceito de soberania, além de ser mais abrangente, torna impossível desassociar a segurança alimentar de seus sistemas produtivos e do desenvolvimento local dessas comunidades.

\subsection{REPENSANDO POLITICAS PUBLICAS ALIMENTARES}

As políticas assistenciais que chegam até esse território quilombola, como o PBF e as cestas básicas distribuídas pela CONAB, atingem o objetivo de redução da insegurança alimentar das famílias beneficiadas. Entretanto, mostramos que elas, de maneira isolada, não conseguem retirar por completo as famílias rurais dessa condição, sendo necessários outros tipos de políticas públicas, que salvaguardem a diversificação produtiva e a manutenção das diversas localidades relacionadas aos sistemas alimentares.

Também é preciso que se repense que parcela do conceito de segurança alimentar realmente está sendo trabalhado, a fim de se focar nas que não estão sendo contempladas, como os aspectos do meio ambiente, da autenticidade e da solidariedade. Concomitantemente, as parcelas negligenciadas devem fazer parte de políticas públicas que visem a segurança alimentar de longo prazo, ou seja, que visem a autonomia dessas populações.

As diretrizes do Plano Nacional de Segurança Alimentar e Nutricional (2012/2015) contemplam largamente tais aspectos, como na diretriz número dois, que postula a "promoção do abastecimento e estruturação de sistemas decentralizados, de base agroecológica e sustentável de produção, extração, processamento e distribuição de alimentos" (CAISAN , 2011). Entretanto, na efetivação desses projetos, tais elementos se 
perdem, e muito do que se realiza nas comunidades está relacionado à quantidade de alimentos, como no caso das cestas básicas.

Este trabalho identificou alguns pontos críticos, que poderiam ser foco de futuras políticas públicas locais, como a indícios da alteração de espécies locais por comerciais, a autonomia produtiva das famílias e o incentivo às atividades extrativistas como complementação da renda e da alimentação familiar. Esses pontos, entre outros, podem tanto auxiliar as famílias a saírem da situação de insegurança, como a atingirem a soberania alimentar. 


\section{CONCLUSÃO}

Entre as conclusões alcançadas por esta pesquisa, destaca-se a de que é possível reduzir e/ou eliminar a insegurança alimentar das famílias rurais, principalmente daquelas em situação de vulnerabilidade extrema, como é o caso dos quilombolas. Mas para que as políticas públicas avancem nesse sentido, antes é importante conhecer os sistemas alimentares aos quais se pretende auxiliar, compreender as suas dinâmicas, seus atores e seus produtos, além de conhecer os elementos externos a eles, mas que impactam as suas teias de relações. Nesse intuito o presente trabalho buscou caracterizar esses elementos que definem o sistema alimentar Kalunga, e que, junto da sua cultura secular, passam por um acelerado processo de mudanças.

A histórica resistência dessas comunidades, que fugiram em busca de liberdade, baseou-se em um sistema de invisibilidade, que privilegiava uma distribuição espacial que ocultasse as moradias, impossíveis de serem vistas por aqueles que passavam pelas estradas. Essa dinâmica também determinava a dispersão das terras produtivas e as distâncias das casas até as roças, que se mantinham curtas, visando o escoamento da produção até as residências, onde os alimentos seriam processados e armazenados para o consumo.

A partir da década de 1980, a pressão fundiária, o crescimento do turismo e a eminência da titulação das terras quilombolas, levaram a um maciço movimento de grilagem de suas terras. Essas investidas contra os direitos fundiários da comunidade Kalunga, muitas vezes foram violentas e baseadas em intimidações físicas, que levaram as famílias a se deslocarem para núcleos onde as terras não eram tão produtivas, mas havia a segurança da proximidade com outras famílias. Algumas localidades, hoje parecidas com vilarejos, se iniciaram dessa forma. Essa alteração da configuração espacial das famílias também alterou as estratégias de diversificação produtiva em decorrência de falta de terras férteis, distância até as áreas de roça e dificuldade de transporte da produção.

Assim, as famílias Kalungas finalizaram o século $X X$ sofrendo com as alterações produtivas impostas pelos grileiros e pela condição irregular de suas terras, mas adentraram o século XXI com o título de Território Quilombola e a criação do Sítio Histórico e Cultural Kalunga. Junto do reconhecimento vieram também as políticas públicas específicas, que visavam superar a situação de vulnerabilidade a qual essa comunidade havia sido exposta. Dessa forma, iniciaram-se os programas assistenciais, como o de transferência condicionada de renda e o de distribuição de cestas básicas. 
Essas medidas compensatórias buscavam, e ainda buscam, diminuir a situação de insegurança alimentar em que essas famílias vivem, seja na forma do benefício monetário, que permite às famílias determinar suas prioridades de consumo, quanto na forma das cestas básicas, que pretendem aumentar a quantidade de alimento disponível mensalmente para cada família contemplada.

Paralelo a essas questões, iniciou-se o crescimento turístico em toda a região da Chapada dos Veadeiros, que busca a contemplação de atrativos naturais e a visitação de áreas selvagens e de preservação. Apesar de não se distribuir de forma homogênea pelas comunidades Kalungas, a o dinheiro advindo das atividades relacionadas ao turismo, tem tido impactos consideráveis sobre a renda das famílias envolvidas, despontando como uma alternativa econômica sustentável para as famílias envolvidas.

Apesar dos dados indicarem ainda uma predominância do quadro de insegurança alimentar leve, essa situação é muito mais otimista do que o esperado, podendo indicar uma relação entre a combinação de cinco fatores principais (roças, extrativismo, PBF, cesta básica e turismo) e o aumento da segurança alimentar nas famílias que conseguem manter todas essas atividades e benefícios. A estratégia de manter-se uma renda diversificada, ao invés da especialização produtiva, parece indicar um caminho mais seguro para as famílias Kalungas, quando essas podem dispor de todos os seus espaços associados aos sistemas alimentares.

Esse relativo aumento da segurança alimentar, no entanto, tem deixado de lado alguns aspectos relacionados com a autenticidade, a liberdade e soberania dos quilombolas, podendo indicar um agravamento da troca de espécies locais por espécies modificadas, o abandono de cultivos locais e a perda da autonomia produtiva. A partir da perspectiva da Soberania Alimentar, tais aspectos são indissociáveis da busca pela segurança alimentar e nutricional dos povos, e por isso merecem ser foco de políticas públicas específicas que auxiliem na autonomia produtiva local.

Ao mesmo tempo em que algumas perguntas são parcialmente respondidas, outras tantas se levantam indicando as inúmeras possibilidades a serem exploradas nesse campo da cultura Kalunga, como por exemplo a questão de como se configuram as diferenciações socioeconômicas que estão crescendo dentro das comunidades. Também parece urgente que se realizem levantamentos etnobotânicos voltados para a agrobiodiversidade, dentro do território, a fim de se conhecer mais profundamente as variedades locais e os seus conhecimentos associados. Nesse caso seria interessante que o levantamento fosse 
realizado por membros da comunidade, ou por equipes mistas, estimulando-se a intercientificidade.

As adaptações observadas evidenciam como os Kalungas são sujeitos ativos sobre os processos de decisões relacionados aos seus sistemas alimentares e produtivos, selecionando os elementos das políticas públicas que irão compor sua realidade, indicando estratégias flexíveis de diversificação da renda familiar. E apesar de podermos enumerar diversos motivos pelos quais a cultura Kalunga deve ser conhecida e zelada, como a agrobiodiversidade (UNGARELLI, 2009), a proteção de áreas nativas e da biodiversidade do bioma Cerrado (BARBOSA, 2008) e as tradições culturais (MAGALHÃES, 2013), o mais relevante é o fato dela ser uma cultura única, e como todas as outras, ter o direito de se manter de forma autônoma, dentro dos seus modos e saberes, até quando seus atores assim quiserem. 


\section{REFERÊNCIAS BIBLIOGRÁFICAS}

ADAMS, C. Caiçaras na Mata Atlantica: pesquisa científica versus planejamento e gestão ambiental. São Paulo: Amablume/FAPESPE, 2000.

AGUIAR, M. D. S.; CAMARGO, A. J. A. Cerrado: ecologia e caracterização. Brasília: Embrapa, 2004.

ALMEIDA, A. W. Os Quilombso eas Novas Etnias. In: O’DWYER, E. C. Quilombos: identidate étnica e territorialidade. Rio de Janeiro: FGV, 2002.

ALMEIDA, A. W. B. D. Os quilombos e as novas etnias. Revista Palmares: quilombos no Brasil, Brasília: Fundação Cultural Palmares, 2000.

ALMEIDA, J. G. D. A Organização Espacial e ocupação territórial no Kalunga: a moradia como efetivadora. Paranoá - Periódico Eletrónico de Arquitetura e Urbanismo da UnB, Brasília, 2005.

AMADO, L. F. Da Opressão à Resistência. In: MOLINA, S. F. O Brasil Também é Negro. Goiânia: UCG, 2004.

ANSCHAU, R.; MATSUO , T.; SEGALL-CORRÊA, A. M. Insegurança alimentar entre beneficiários de programas de transferência de renda. Revista de Nutrição, Campinas, v. 25(2), p. 177-189, mar/abr 2012

AVELAR, A.; DE PAULA, M. V. Comunidade Kalunga : trabalho e cultura em terra de negro. GEOgraphia, n. Ano V n.9, p. 115-131, 2003.

AZIZ, C. A Arribação dos Calungas. Folha do Povo, Ipameri, v. Ano 1. nำ, 1970.

BAIOCCHI, D. N. Kalunga: Povo da Terra. Brasília: Ministério de Justiça, Secretaria de Estado dos Direitos Humanos, 1999.

BAIOCCHI, M. D. N. Kalunga : a sagrada terra. Revista da Faculdade de Direito da UFG, Goiânia, v. 19/20, n. n.1, p. 107-120, Jan/Dez 1996.

BARBOSA, A. G. As Estratégias de Conservação da Biodiversidade na Chapada dos Veadeiros: conflitos e oportunidades. Brasília-Df: Dissertação de Mestrado - CDS/UnB, 2008.

BARRETO, J. N. Implatação de Ifraestrutura Habitacional em Comunidades Tradicionais: o caso da comunidade quilombo Kalunga. Brasília: Dissertação de Mestrado FAU-UnB, 2006. 
BARRETTO FILHO, H. T. Populações Tradicionais : Introdução à critica da ecologia política de uma nação. Sustentabilidade e Políticas de Desenvolvimento, p. 109-143, 2006.

BRASIL (a). Lei no 11.346, de 15 de julho de 2006. Cria o Sistema Nacional de Segurança Alimentar e Nutricional - SISAN. Diário Oficial da República Federativa do Brasil. Brasília, DF. Disponível em: <https://www.planalto.gov.br/ccivil_03/_Ato20042006/2006/Lei/L11346.htm >. Acesso em: 11 de outubro de 2014.

BRASIL (b). Ministerio do Desenvolvimento Social e Combate a Fome (MDS) Programas de Abastecimento Social. Companhia Nacional de Abastecimento, 2014. Disponivel em: $<$ http://www.conab.gov.br/conteudos.php?a=564\&t=2\#this >. Acesso em: 11 outubro 2014.

BRASIL (c). Bioma Cerrado. Ministério do Meio Ambiente (MMA), 2014. Disponivel em: <http://www.mma.gov.br/biomas/cerrado>. Acesso em: 11 Outubro 2014.

BRASIL. Constituição da República Federativa do Brasil: promulgada em 5 de outubro de 1988. 42. ed. São Paulo: Saraiva, 2009.

BRASIL. Uma História do Povo Kalunga. Brasília - DF: Ministério da Educação Secretaria de Educação Fundamental, 2001.

BRAUW, A. et al. The Impact of Bolsa Família on Women's Decision-Making Power. World Development, v. 59, p. 487-504, 2014.

CAISAN. Plano Nacional de Segurança Alimentar e Nutricional 2012/2015. CAISAM. Brasília, DF, p. 132. 2011.

CAMPOS, E. S.. Relatório Final do Estudo Diagnóstico : o turismo nas comunidades Kalunga do Vão de Alma, Vão do Moleque e Engenho II - potencialidades, desafios, dificuldades e ações para o desenvolvimento do turismo cultural, rural e ecológico de base comunitária. Fundação Banco do Brasil - Instituto para o Bem Estar do Funcionalismo Público. Brasília. 2011.

CANCI, I. J. Relações dos Sistemas Informais de Conhecimento no Manejo da Agrobiodiversidade no Oeste de Santa Catarina. Florianópolis: Dissertação de Mestrado Universidade Federal de Santa Catarina, 2006.

CARRIL, L. Terras de Negros: heranças de quilombos. São Paulo: Scipione, 1997.

CHIANCA, P. P. Nas vias do reconhecimento: emergência etnica e territorialização Kalunga. Brasília -DF: Dissertação de Mestrado - CDS/UnB, 2010. 
CHONCHOL , J. A Soberania Alimentar. Estudos Avançados, v. 19(55), 2005.

CORDEIRO, D. M. Excesso de peso em estudantes quilombolas e a insegurança alimentar em seus domicílios. Goiânia: Dissertação de Mestrado - Faculdade de Nutrição/UFG, 2013.

COSTA, V. S. A Luta pelo Território: histórias e memórias do povo Kalunga. Brasília, Planaltina - DF: Monografia, LedoC - UnB, 2013.

CROMWELL, E.; COOPER, D. . M. P. Definiendo la biodiversidad agrícola. In: CIPUPWARD Conservación y uso sostenible de la biodiversidad agrícola: Libro de consulta. Los Baños, Filipinas: [s.n.], v. 1, 2003. p. 5-13.

DA MATTA, R. O que faz o Brasil, Brasil? Rio de Janeiro: Rocco, 1986.

DAMANDO, G. I. Os Impactos do Turismo em Cavalcante - GO. Brasília: Trabalho de Especialização - Universidade de Brasília / Turismo, 2003.

DIAMOND, J. Armas, Germes e Aço. 14ํ․ ed. Rio de Janeiro - São Paulo: Record, 2012.

DRUMMOND, J. A. Proteção e Produção: biodiversidade e agricultura no Brasil. 1. ed. Rio de Janeiro: Garamond, 2014.

ECHEVERRY, S. M. V. Impactos da eletrificação no meio rural em comunidades quilombolas: caso dos Kalungas, Cavalcante-GO. Planaltina-DF: Dissertação de Mestrado - FUP/UnB, 2014.

ELOY, L.; BRONDIZIO, E. S. New perspectives on mobility, urbanization, and resource management in riverine Amazônia. Bulletin of Latin American Research, 2014.

ELOY, L.; CARVALHO, I. S.; FIGUEIREDO, I. Sistemas Agrícolas Tradicionais no Cerrado: caracterização, transformações e perspectivas. In: SANTILLI, J.; BUSTAMANTE, P.; BARBIERI, R. L. Agrobiodiversidade e Agroecologia. Coleção Transição Agroecológica. [S.I.]: ABA/Emprapa, no prelo 2014.

ELOY, L.; LASMAR, C. Urbanização e transformação dos sistemas indígenas de manejo de recursos naturais: o caso do alto rio Negro (Brasil). Acta Amazonica, v. 41(1), p. 91-102, 2011.

EMPERAIRE, L. História de Plantas, Histórias de Vida: uma abordagem integrada da diversidade agrícola tradicional na Amazônia. Atas do VI Congresso SBEE. Porto Alegre: [s.n.]. 2006. 
FAO. Pessoas saudáveis dependem de sistemas alimentares saudáveis : Dia Mundial da Alimentação, 16 de outubro de 2013.. Organização das Nações Unidade para a Alimentação e Agricultura, 2013. Disponivel em: <https://www.fao.org.br/psdsasDMA2013.asp>. Acesso em: 30 out 2013.

FAUSTO, B. História do Brasil. 4․ ed. São Paulo: EDUSP/FDE, 1996.

FELIZOLA, E. R.; FELFILI, J. M. Planejamento de corredor ecológico entre duas áreas nucleares da Reserva da Biosfera Cerrado - Fase I. In: ARRUDA, M. B. Gestão Integrada de Ecossistemas. Brasília: Ibama, 2006. p. 37-46.

FIORAVANTE, M. C. S. et al. Reintrodução do Gado Curraleiro na Comunidade Quilombola Kalunga de Cavalcante, Goiás, Brasil: Resultados Parciais. II Simpósio Internacional Savanas Tropicais, Brasília-DF, Outubro 2008.

FRANCO, J. L. D. A. A contribuição do Turismo na Preservação e na Socioeconomia das Nações: Uma pesrpectiva Histórica. II Congresso de Natureza, Turismo e Sustentabilidade - CONATUS, Cuiabá - MT, Outubro 2011.

FRANCO, R. D. A Desapropriação e a Regularização dos Territórios Quilombolas. Goiânia: Dissertação de Mestrado - Faculdade de Direito/UFG, 2012.

GEERTZ, C. A Interpretação das Culturas. Rio de Janeiro: LTC, 2012.

GIUSTINA, C. C. D. Degradação e conservação do cerrado: uma história ambiental do estado de Goiás. Brasília: Tese de Doutorado, UnB, 2013. 210 p.

GODINHO, T. M. O Lugar da Mulherno Quilombo Kalunga. São Paulo: Dissertação de Mestrado, PUC, 2008. $156 \mathrm{p}$.

GÓMEZ-POMPA, A.; VÁZQUEZ-YANES, C.; GUEVARA, S. The tropical rain forest: a nonrenewable resource. Science, v. 177:762-5, 1972.

JATOBA, D. A Comunidade Kalunga e a Interpelação do Estado: da invisibilidade à identidade Política. Brasília: Dissertação de Mestrado - DAN UnB, 2002.

KATZ, E. Alimentação Indígena na América Latina: comida invisível, comida de pobres ou patrimônio culinário? Espaço Ameríndio, Porto Alegre, v. 3 n.1, jan/jun 2009.

LIENHARD, M. O Mar e o Mato: Historia da Escravidão (Congo, Angla, Brasil, Caribe). Salvador, Bahia: E DU FBA/CEAO, 1998. 
LIMA, J. E. F. W.; SILVA, , E. M. Análise da situação dos recursos hídricos do Cerrado combase na importância econômica e socioambiental de suas águas. [S.I.]: [s.n.], 2008.

LIMA, L. N. M.; NAZARENO, E. Manifestações Culturais em território Kalunga : A Festa de Nossa Senhora de Aparecida como Elemento de (re)afirmação identitária e reaproximação étnica. REMIE - Multidisciplinary Journal of Educational Researh, 2 n.1, Fevereiro 2012. 105-127.

LIMA, N. M. D.; ALMEIDA, M. G. Identidade Territorial Kalunga: A cultura e a Relação com o Cerrado como Possibilidades para o Desenvolvimento do Turismo Sustentável nas Comunidades Quilombolas de Teresina de Goiás. II Gongresso Internacional de História da UFG, Jataí, 2011.

LIMA, P. C. A. D. As RPPNs da Chapada dos Veadeiros: disposições, motivações e práticas sociais. Brasília: Dissertação de Mestrado, CDS - UnB, 2013.

LITTLE, P. E. O Conhecimento Tradicional no Marco da Intercientificidade. In: LITTLE, P. E. Conhecimentos Tradicionais para o Século XXI. São Paulo: Annablume, 2010. p. 9-31.

MACIEL, M. E. Uma cozinha à brasileira. Estudos Históricos, Rio de Janeiro, v. 33, p. 2539, jan-jun 2004.

MACIEL, M. E. Identidade Cultural e Alimentação.. Antropologia e Nutrição, Rio de Janeiro, Editora Fiocruz 2005.

MAGALHÃES, N. A. Senhora D’Abadia: Festejo Kalunga no Vão de Almas, Cavalcante GO. Brasília: Verbis Editora, 2013.

MARINHO, T. A. Identidade e Territorialidade entre os Kalungas do Vão do Moleque. Goiânia: Dissertação de Mestrado - Faculdade de Ciências Humanas e Filosoficas - UFG, 2008.

MASSAROTTO, N. P. Diversidade e Uso de Plantas Medicinais por Comunidades Quilombolas Kalungas e Urbanas no Nordeste do Estado de Goiás -Go, Brasil. Brasília: Dissertação de Mestrado - FT/UnB, 2009.

MATTOSO, K. Q. Ser Escravo no Brasil. São Paulo: Brasiliense, 1990.

MYER, N. et al. Biodiversity hotspots for conservation priorities. Nature, 2000.

NAVES, V. F. A. Pesquisa-Ação e Etnografia : Caminhos Cruzados. Pesquisas e Práticas Psicossociais, São João del Rei, v. 1, junho 2006. 
NEIVA, A. C. G. R. et al. Caracterização Socioeconômica e Cultural da Comunidade Quilombola Kalunga de Cavalcante, Goiás, Brasil : dados preliminares. IX Simpósio Nacional Cerrado, Brasília, Outubro 2008.

NEIVA, A. C. G. R.; SERENO, J. R. B.; FIORAVANTE, M. C. S. Indicação Geográfica na Conservação e Agregação de Valor ao Gado Curraleiro da Comunidade Kalunga. Archivos de zootecnia, v. 60(231), p. 357-360, 2011.

OLIVEIRA, E. C. D. O medo dos colonizadores em relação ao indígena na expanção da fronteira colonizadora, em Goiás, nos séculos XVIII e XIX. In: SILVA, S. D., et al. Fronteira Cerrado: Sociedade e natureza no oeste do Brasil. Goiânia: PUC Goiás, 2013. p. 87-102.

PALACÍN, L. Goiás 1722 - 1822: estrutura e conjuntura numa capitania de minas. Goiânia: Oriente, 1972.

PELWING, A. B.; FRANK, L. B.; BARROS, I. I. B. Sementes crioulas: o estado da arte no Rio Grande do Sul. Revista de Economia e Sociologia Rural, Piracicapa -SP, v. 46 n.02, p. 391-420, abr/jun 2008.

PEREIRA, K. J. C. Agricultura tradicional e manejo da agrobiodiversidade na Amazônia Central: um estudo de caso nos roçados de mandioca nas Reservas de Desenvolvimento Sustentável Amaná e Mamirauá, Amazonas. [S.I.]: Tese de Doutorado - Escola Superior de Gricultura Luiz Queiroz / Centro de Energia Nuclear na Agricultura, 2008. 222 p.

PEREIRA, M. B.; ALMEIDA, M. G. D. O Quintal Kalunga como Lugar e Espaço de Saberes. GEONORDESTE, v. XXII n.2, p. 47-64, 2011.

PETRINI, C. Slow Food: princípios da nova gastronomia. São Paulo: Editora Senac, 2009.

PIVELLO, V. R. Fire management for biological conservation in the Brazilian cerrado. In: MISTRY, J. \&. B. A. (. ). Savannas and dry forests: linking people with nature. [S.I.]: [s.n.], 2006. p. 129-154.

RIBEIRO, J. F.; WALTER, B. M. T. Fitofisionomias do Bioma Cerrado: os biomas do Brasil. In: Cerrado: ambiente e flora. Planaltina-DF: EMBRAPA, 1998. p. 89-116.

ROCHA, A. P. D. C. Entre Culturas: Quilombola e Indígena. Brasília: Monografia - CDS UnB, 2009.

ROSA, W. D. S. Reza, Rezadeiras e Juventude na Comunidade Vão de Almas, Cavalcante - GO. Planaltina - DF: Monografia FUP-UnB, 2013. 
SANTANA, J. A. A Evolução dos Programas de Transferência de Renda e o Programa Bolsa Família. In: Seminário População , Pobreza e Desigualdade. Belo Horizonte, MG: Cedeplar/UFMG, 2007. p. 1-19.

SANTILLI,. Agrobiodiversidade e direitos dos agricultores. [S.I.]: Editora Peirópolis, 2009.

SARDO, P. Doméstico e Selvagem. Almanaque Slow Food 2008/2009, San Mauro Torinese, 2008.

SEGALL-CORREA, A. M.; SALLES-COSTA, R. Novas possibilidades de alimentação a caminho? Democracia Viva, v. 39, p. 68-73, Jun 2008.

SEN, A. K. Desenvolvimento como Liberdade. São Paulo: Companhia das Letras, 2000.

SEPPIR-FUBRA. Levantamento Sócio Econômico e cultual quilombola Klaunga. UnB. Brasília. 2004.

SILVA, R. D. J.; GARAVELLO, M. E. D. P. E. Ensaio Sobre Transição Alimentar e Desenvolvimento em Populações Caboclas da Amazônia. Revista Segurança Alimentar e Nutricional, v. XIX n.1, p. 1-7, 2012.

SIMINSKI, A.; FANTINI, C. Roça-de-toco: uso de recursos florestais e dinâmica da paisagem rural no litoral de Santa Catarina. Ciências Rurais, Santa Catarina, v. 37 n.3, p. 690-696, mai-jun 2007.

SIQUEIRA, R. C. D. M. Instrumentos Jurídicos para a Organização das Atividades Agrárias da Comunidade Kalunga do Engenho II. Goiânia: Dissertação de Metrado Faculdade de Direito/UFG, 2012.

SIQUEIRA, T. T. D. Dos tempos da sussa aos tempos do forró: música, festa e memória entre Kalungas de Teresina de Goiás. Dissertação de Mestrado - UnB -Brasília: [s.n.], 2006.

SIRICO, H. L. A. Análise do turismo e seus impactos socioculturais na comunidade Kalunga (GO). Rosana-SP: UNESP, 2008.

SOUZA, B. O. Aquilombar-se: panorama histórico, identitário e político do movimento quilombola brasileiro. Brasília: Dissertação de Mestrado, UnB, 2008.

SOUZA, L. R.; BELIK, W. O Planejamento da Política de Alimentação: uma análise a partir dos casos do México, Brasil e Peru. Revista Segurança Alimentar e Nutricional, v. XIX n.2, p. 111-129, 2012. 
SPRADLEY, J. P. Participant observation. New York: Holt, Rinehart and Winston , 1980.

TIBURCIO, B. A.; VALENTE, A. L. E. F. O comércio justo e solidário é alternativa para segmentos populacionais empobrecidos? Estudo de caso em Território Kalunga (GO). Revista de economia e sociologia rural, v. 45, p. 497-519, 2007.

TRALDI, D. R. C.; ALMEIDA, L. M. M. C.; FERRANTE, V. L. S. B. Repercussões do Programa Bolsa Família no Município de Araraquara, Sp: um olhar sobre a segurança alimentar e nutricional dos beneficiários. INTERAÇÕES, Campo Grande, v. 13 n.1, p. 23-37, jan/jun 2012.

UNGARELLI, D. B. A Comunidade Quilombola Kalunga do Engenho II: Cultura, Produção de Alimento e Ecologia dos Saberes. Brasília: Dissertação de Mestrado, Centro de Desenvolvimento Sustentável - UnB, 2009.

VALENTE, A. L. E. F. (In) Segurança Alimentar em Território Kalunga. XIII Congresso Brasileiro de Sociologia, Recife (PE), Maio/Junho 2007.

VELLOSO, A. D. Mapeando Narrativas: uma análise do processo histórico-espacial da comunidade Engenho II - Kalunga. Brasília: Dissertação de Mestrado - GEA/UnB, 2007.

\section{VIA CAMPESINA. Soberania Alimentar, os Agrocombustíveis e a Soberania} Energética. Brasil: Via Campesina Internacional, 2007.

VIZOLLI, I.; SANTOS, R. M. G.; MACHADO, R. F. Saberes Quilombolas: um estudo no processo de produção da farinha de mandioca. Bolema, Rio Claro (SP), v. 26 n.42B, p. 589608, abr 2012. 